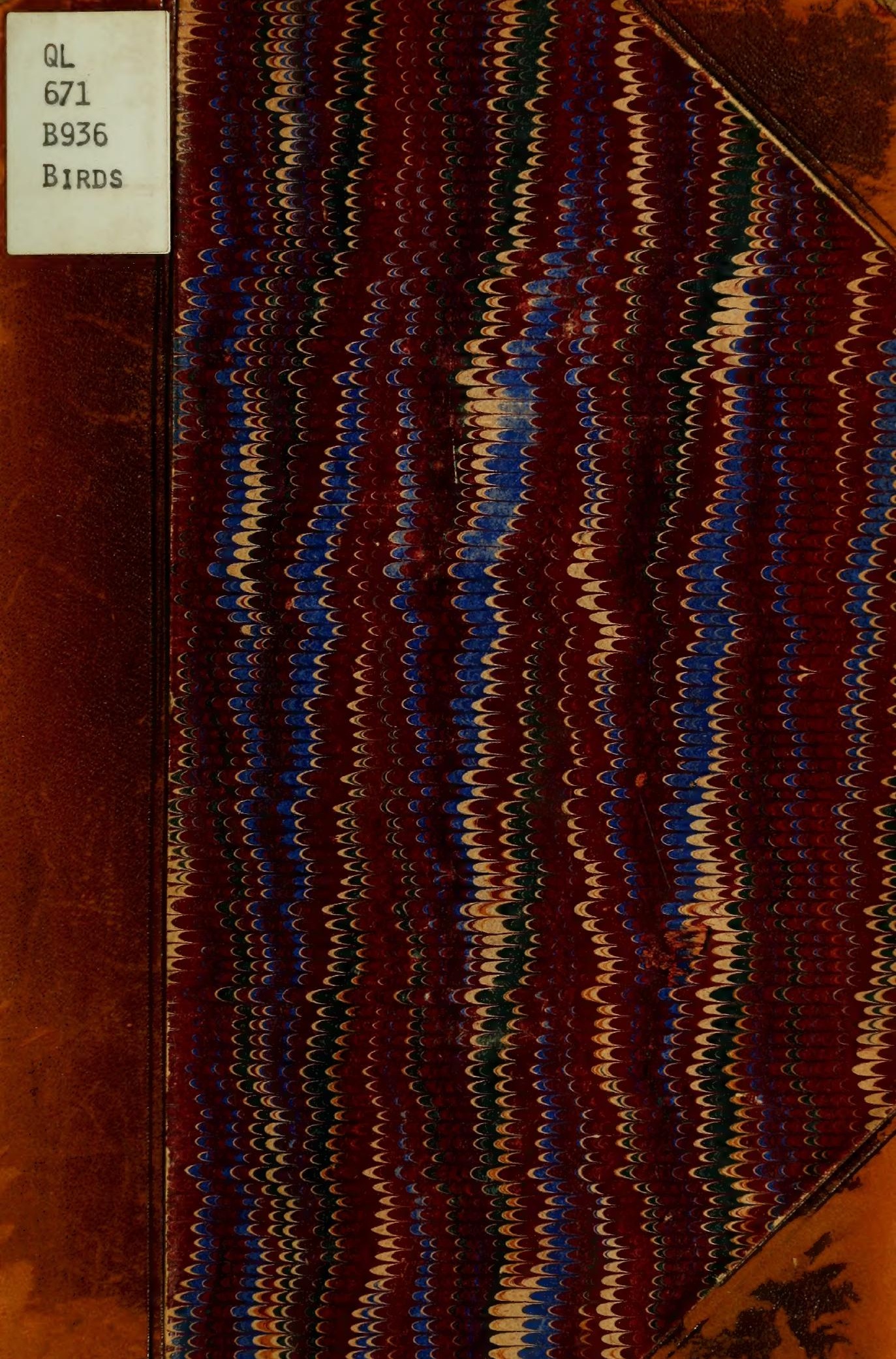








Origive aize $15 \times 22 \mathrm{~km}$. 
TOGWYY ORNITHOLOGICAL

RIDUNA ORETHOLOGLCL CLUP,

OF

Chicago, Illinois, U. S. A.

BuLlemin No. 1.

Bird Migration in the Mississippi Valley

W. W. G00KE AND OTTO WIDMANN.

PUBLISHED BY

The American Field,

DECEMRER, ISS 3 . 

Compliments of

\section{The Ridgway Ornithological Club.}

"nivications you Suciety will be very accetabie in exchange.

$$
\begin{aligned}
& \text { Restect } u \text { I! } \\
& \text { H. K. COALE, Sec'y, }
\end{aligned}
$$

340 Waush Ave. Chicago. Ill., L. S. A. 



\section{BIRD MIGRATION}

IN THE

Mississippi VAlley,

W. W. COOKE and OTTO WIDMANN.

RIDGWAY ORNITHOLOGICAL CLUE,

November $S$, ISS3.

\section{$1267 / 3$}

PUBLISHED IN TILE " AIERICAN FIELI)" Vor. XX, No. 22, to VoL. XXI, No. 3. 



\section{PART I. INTRODUCTION.}

\section{(W. W. COOKE.)}

During the Spring of 1882 a series of observarions on the migration of birds in the Mississippi Valley was conducted under my supervision. The notes collected were published in the Frost and Strean during October and November of that year. A more extended series has been successfully conducted the past Spring, and it is intended in these articles to' give the full notes from two points in the Mississippi Valley, namely, St. Louis, Mo., the observer here being Mr. O. Widmann, 4024 Carondelet Avenue; and Jefferson, Wis., where I was living the past year. This is done that these notes may serve not only as guides to future observers in determining when to look for each species, but as showing how necessary it is that observations, to be atall satisfactory, should be full, accurate, taken almost daily, and connected with a careful record of the meteorology of the place of observation.

Full as these notes are, compared with the large majority of "Spring notes," a careful study of them will show how much more valuable they would have been had they been connected with a third station mid-way be. tween, and if in connection with them could be had an exact weather report from a place one hundred and fifty or two hundred miles south of St. Louis; since, of course, it will be readily granted by all, that it is not the weather of the place of arrival which controls the movements of our birds-except in rare cases-but rather the atmospheric conditions of the place from which the bird starts on its migratory flight.

To make the record of these two stations as intelligible as possible, it is deemed best to clescribe the character of the country in full, and the conditions under which the observations were made.

The ground worked in St. Louis was the south end of the city, along the west bank of the Mississippi, which is here about seventy-five to a luundred feet high, and the top of which consists of a long series of sink holes or shallow pits of a quarter to half an acre in extent, clensely overgrown with bushes and low trees. The whole southern part of St. Louis is well supplied with shrubs and large trees, furnishing convenient stopping places for our feathered travelers, but the greater part of the notes were made in the heavy timber which skirts the banks of the River des Peres, a small stream which marks the city limits on the west and then turning toward the east enters the Mississippi a little way south of the city. In these woods the observer Was alone with Nature and the birds, and, though so near the city, yet was as free from interruption and disturbance as if in the big woods of the Northwest. Opposite St. Louis, on the Illinois side of the river, are extensice low. lands overgrown by willows and heavy underbrush. Occasional risits were pail to these places, but the notes there taken have always been credited to Illinois, and no notes are credited to St. Louis unless they were actually marle on the Missouri side of the river. The trips for observation were 
taken almost daily, and consisted, during the busiest time of the season, of a six to eight-mile journey to the woods, starting at 4:30 A. M., and after sereral hours' actual work in the woods, returning at noon, or often late in the af ternoon. To these were added many evening excursions, and a constant watch over the movements of such birds as could be found in the heart of the city. A good field-glass was constantly in use, and the shotgun appealed to if any doubt still remained. Having many years of previous study in the same locality to draw upon, this last method was seldom required. It might be added that the country is practically destitute of large bodies of pines, and of any prairieland, which may account for the strange absence of some birds found in abundance at places not far distant.

The other station, Jefferson, Wisconsin, is in the south-eastern part of that state, midway between Milwaukee and Madison. It is a small town of some 2,500 inhabitants, situated on both sides of the Rock River, just north of its juncture with the Crawfish River. My house was situated on the west bank of the Rock River, seventy feet above its surface and both my yard and the yards on each side wero plentifully supplied with hardwood trees and several varieties of pines. A quarter of a mile's walk westward brought me out of town into rather thinly settled country, with patches of hardwool timber scattered quite frequently around. A half-mile more brought me to the Crawfish River, there flowing southward, but soon bending to the East, and joining the Rock River a half-mile south of my place. The surface of the country for a mile and a half east and west is flat, constituting what is known as the RockRiver Valley. The higher ground farther west was not visited, and all the notes are of the movements of the birds in the valley.

Most of the notes were made on the banks of the Crawfish, at the south enc of town, where it was flowing east and west. There, within a radius of a third of a mile, could be found hill and valley-on a small scale-heavy first-growth timber, second-growth brush, marsh, prairie, and mud flats along the river. And no matter which way the wind blew, sheltered spots could always be found. North of town, two miles, at a place called Jefferson Junction, is a large stretch of tamarac swamps, broken by higher land and occasional groves of hardwood. Here bird-life was always found in greater abundance than along the Crawfish, and the trips taken there every Saturday furnished much material for the note-book and the colleciing-box. The work of the season consisted in almost daily visits to the woods from $6 \mathrm{~A}$. M. to 8 A. M. five days in the week, with a more extended trip and longer time on Saturdays. Many tramps were also taken after school hours in the the afternoon. On many of the cold days the birds were hardly thawed out by $80^{\prime}$ clock, but although science is good for recreation, bread and butter must be earned, and the school-room demanded my time from 8:30 A. M. to 4 P. M.

In the following notes the plan has been to give first the weather record and the general notes from St. Louis, then the same from Jefferson, and lastly the combined notes on each species separately. The nomenclature used is the latest Smithsonian catalogue. 


\section{PART II.}

\section{GENERAL NOTES AND WEATIIER REPORT FROM ST. LOUIS, MO., BEGINNING WITH JANUARY 1, 1883.}

\section{O. WIDMANN.}

We have had unusually cold and disagreedhle weather since the first of January. Old Boreas was reigning and kept the ground white, and the temperature below the pleasure-point for ornithological field work. January was cold and windy. February tried to make things better by a two days' rain, with the mercury below $30 \mathrm{dgs}$. Of course it succeeded splendidly in making matters worse, for everything from the smallest blade of grass to the largest tree was corered with a heavy coat of glittering ice. Consequently ornithology had to go on skates or stay at home. This miserable weather lasted a whole week, from the $3 d$ to the $10 t h$. On the 14th, however, a warm rain and a strong breeze from the south raised the mercury to $62 \mathrm{dgs}$.

This first warm breeze brought the first flock of ducks, and since that time thousands and thousands have gone north. Between 4 and 5 p. m., on the 15th, twenty-eight large flocks passed over, and at 5 p. m. twenty gulls were in sight, passing slowly up in beautiful gyrations; two small and two very large flocks of geese were also seen. Between 7 and 8 p. m., on the 16th, I couned over fifty flocks of ducks, aggregating over two thousand individuals, going the same way and at the same height. To-night the mercury stands at 25 dgs., and all is white and hard again. Did these ducks know about this aproaching great change in the weather and did not mind it, or contrary to the theory of some ornithologists, are unable to read probabilities?

Since this first south-wind period seems to mark a new era in our bird life it will be well to close the chapter of mid-Winter notes now and report what I have seen.

As the weather during the first six weeks of this year did not permit excursions to new fields, I contentel myself with revisiting the ground gone orer in December, to see what had become of my little friends enumerated in my New Year's report.

Of the three mocking birds mentioned there, two stood the weather bravely and are doing well, but the other has not been seen since the freezing rain of February 3. Bluebirds have also remained at their old places, and as a sign that they did not suffer even during the ice storm, the first mild day two males were already courting a female, with as fine a carol as ever was heard in Spring.

Titmice, chicadees, wrens and nutbatches are not disturbed by any kind of winter weather, as they can find food where few other birds would think of looking for it, while tree holes afford them unexcelled shelter. Nevertheless they all appreciate southerly winds, and become loquacious in their exultations over a big rise in temperature.

Most, but not ail of the yellow.rumped warblers have vanished. The pur- 
ple finches have become very intmerous, large numbers collecting during the "glacial period" in every place where the coral berry or Indian turnip grows. During those cold days, when everything, even their favorite sycamore buttons, was covered with a sheet of ice, they had to put up with this meager food. They worked hard all day to appease their hunger, and then were not satisfied. Hard, unsatisfactory work it was for them, as they do not eat the whole berry, hut merely the small seeds within, and even these they have to husk before swallowing. After the birds had worked there a few days, the ground was coveredwith the husks, skins and pulp. On six acres, overgrown with patches of this plant, I found about a hundred purple finches. About ten per cent. were in crimson while the rest were in plain brown. When the weather moderated they left the coral berries. The American goldfinch braved the cold of January, but the freezing process of February 3 was too much for them. They have almost wholly disappeared; a walk of nine miles in nine hours revealing only two bircls. White-throated, white-crowned, song and tree spar. rows, and the black snowbird still remained in their winter quarters. Old Pipilo has braved the cold $\pi$ ell, and his call comes from the same thicket as in December, while Mrs. Pipilo is seen not a hundred yards off. The cardinal grosbeak is a hardy feilow, still he likes warm days in Winter better than coll ones. When the sun shone brightly on the 12 th inst. he was much pleased with it and gave vent to a lovely song.

The crow seems to degenerate! It cannot stand so much as it used to. I found them badly starred and frozen with a terribly empty stomach, and the whole bird not more than half its usual weight. Blue jays still know how to keep themselves from starving, or else they manage to live on noise-making.

The downy and hairy wood-peckers remain at their places, and are bound to make lore the first warm day, no matter how deep the mud is. Mr. Redhead tried his best to stay and lire on ice-cold acorns, and such like, but when I met him on cold days he did not say much, and seemed to suffer remorse for not going with his brethren. The flickers remained, and were doing well on the 12 th inst., but they looked as if they were resolved not to stay with us next Winter.

The following is a list of the new species I have seen since my last report :

Pine Goldfinch-One bird on January 18.

Golden-crowned Kinglet-Two pairs on January 6.

Brown creeper-One bird on January 6.

Redpoll Linnet-One bird on February $r$, and a flock of from thirty to thirty-six on the 12th. They were wholly unacquainted with such a thing as a shotgun.

Lapland Longspur-On Jynuary 6 there was a flock of thousands on a tield grown orer with sedge, upon the seeds of which they were feeling eagerly. It appeared as though they had male a contract with the owner of the field to clear it of every seed in the shortest possible time. And how they did work! A pretty hard work it was, too, as they had to husk the minute seeds. They were unwilling leave their task unlone, and a shot had no other effect than to make them go up in a cloud with a noise like thunder, circle a few minutes and then come down again near the same spot. They seemed too, to do the work systemat-ically; every few minutes the rear portion of the 
army fiew over the heats of the others in front, and all moved in the same direction.

Swamp Sparrow-One bird on January 29, in the same place I found one last Winter.

Purple Grackle-Four birds on January 18, and two on the 29th.

A few gulls remained here and were seen several times over the Mississippi at the south part of the city, where the strong current prevented the forming of ice.

Following are the notes for the week from February 18 to 24 :

The weather was cool, partly clear or fair. Northerly winds, and just warm enough to keep the ground in an exceedingly muddy condition. It required more than ordinary energy to pull through in order to be au fait to the doings of the progressing season. The equatorial wave which stirred the water-birds to northward advancing on the fourteenth, fifteenth, and morning of the sixteeńth, and which was so abruptly met by its antagonist, the polar wave, has wrought some changes in the status of our ornis.

The most noticeable change is the great increase of bluebirds, or rather, the arrival of our bluebirds, if we do not count the few birds wintering with us.

Ducks were very plentiful in this neighborhood all the week, but no great move took place until yesterday forenoon, February 24 , when with a light rain and strong, warm (62 dgs.) south wind, large flocks were seen to go north at some height; also troops of Canada geese.

This migratory movement was again abruptly stopped, when at noon the black western horizon announced the oncoming Norther, which, during the afternoon, forced the mercury down to $32 \mathrm{dgs}$. It is still Winter with us, and no changes in our ornis are expected during the next few days.

Although the weather during this week, February 25 to March 4, was fine and seemingly very favorable to the movements of birds, the fact is, that it brought no birds at all. We have had clear skies, lively drying winds, with a warm sun and four frostless nights. We have had all kinds of rinds, but have not had that soft moisture-laden south wind which brings us the dark clouds from the gulf and the birds from the gulf-bordering countries.

On our vegetation the clear, warm skies. and frostless nights have had great effect since February 28. Within three or four days the yellow of the wheat-field has turned into a beautiful green, and many plants, besides the grasses, put forth their young leaves. Around the opening blossoms of the red maple the bees are swarming, and animal life stirs everywhere, since the hot sun of the 28th gave the first start. This last day of February was remarkable as an instance of the great effect which a few hours of sunrays hare in a clear and still air, on an early Spring day. After an extremely clear night, the temperature of the air was a little above ireezing, but the ground was somewhat stiff in the early morning (from radiation, I suppose). Soon, however, the sun began to make itself felt, and at $11 \mathrm{a}$. m. the first frog commenced to croak. At noon a host of hls brethren had joined him on all sides, and by this time the mercury had risen to $113 \mathrm{dgs}$. in the sun.

The mud under the shallow water of the swamps began to move in many places, and small larvæ appeared with writhing motions. Minute black flies danced in the air, and in the dry rubbish ran numbers of spiders to and fro. Craw-fishes of small and large sizes crawled up the banks of the creek, 
over the surface of which a variety of water beetles perambulated. In short, there was life everywhere, where a few hours before the death of Winter had reigned. It seemed to me to be the awakening of Spring, and the scene was perfected when the spirited "honk" of great numbers of departing geese was heard overhead.

This week, March 4 to March 11, was remarkable for its scarcity of birds. No birds have arrived, although we have had two south-wind periods, but of too short duration. On the fourth the wind shifted rapidly from southwest to west, then to northwest, north, northeast, and on the fifth with a light rain, to southeast, and during the night to southwest, the temperature going up all the time from $30 \mathrm{dgs}$. to $50 \mathrm{dgs}$, only to sink down again to $30 \mathrm{dgs}$. during the sixth, with the wind from the northwest increasing in strength.

March 7, clear, cold, tempera ture from 19 to $31 \mathrm{dgs.} \mathrm{Wind} \mathrm{northwest,} \mathrm{north}$ and northeast.

March 8, clear, bright, but cool wind from the southeast and south. Temperature from 22 to $44 \mathrm{dgs}$.

March 9, after a clear, cool night (34 dgs.), we had a clear day with a grood breeze from the south, with a maximum temperature of $64 \mathrm{dgs}$. until the wind changed suddenly to northwest at $5 \mathrm{p} . \mathrm{m}$.

March 10 and 11 we had high winds from the west and northwest, with a partly clear sky, and temperature near freezing.

I had expected many species, which generally arrive during the first ten days of March, but after having been through field and woods all day long on the eighth and ninth, I was certain that not a single chippy nor field sparrow, towhee bunting, American goldfinch, purple grackle, etc., had come.

Just now, we have even less land birds here than in January and February. The bluebirds, robins, meadow larks, and red-winged blackbirds, are the only ones which have arrived and spread, while many Winter visitants have left. The Lapland longspurs and the redpoll linnets have not been seen again; the purple finches have almost all gone. The gold finches have not yet returned. The tree sparrows liave thinned out, and the snow birds are decidedly less numerous.

The eleventh and twelfth brought no change, the weather was cold and windy. The thirteenth was foggy, but two light thunderstorms in the afternoon cleared the atmosphere. Un the thirteenth I met the first field sparow, a male, in song, at the same place where I found the first bird last year, on the first of March (twelve days earlier). The fourteenth was expected to bring many changes, as it was the day after the first shower, followed by a warm night with southwest wind. The day opened brilliantly; a clear sky, soft, pure air, $51 \mathrm{dgs}$, and a light southwest wind. But it was the old story over again, wind and mercury went up too high, and a fierce thunderstorm came i1p and down went the mercury again to $31 \mathrm{dgs}$. on the following day, which remained cold with a strong northwest wind.

The sixteenth was a fine day, cold at first, but gradually growing milder and rery pleasant, with a brisk southwest wind. Birds were active till $1 \mathrm{p} . \mathrm{m}$.

March 17. Another fine day, but no additions.

Sunday (March 18) was fine, the temperature went up rapidly from 51 to 78 dgs. in the afternoon, until the wind shifted from south to north, almost un. noticed at first, as there was no thunderetorm and not a drop of rain, but the 
Norther broke upon us at about $4 \mathrm{p} . \mathrm{m}$., with a velocity of thirty, and at $6 \mathrm{p}$. $\mathrm{m}$. the mercury was down to $46 \mathrm{dgs}$, and at $10 \mathrm{p} . \mathrm{m}$. to $29 \mathrm{dgs}$. It is the greatest change in temperature (within such a short time) that I remember.

Yesterday (March 19) it was cold (19 to 32 dgs.), with a sharp northwest wind, and to day it has been snowing all day with the mercury below $30 \mathrm{dgs}$. I pity the poor martins which were inducel to go so far north last Sunday. I hope they went back a good distance, or else they must perish, as they could find no food, and the nights were too cold for them.

From March 18 to April 3, there was a perfect standstill in everything. The weather being cool, gloomy, with northerly winds, and occasional snow and cold rain. Birds did not move, except Fringillide, which were found more numerous on March 30. The snowbirds were found collected in large flocks, and very excited in spite of the cool rain, and in a place where twenty wintered, I found an army of two hundred, singing, chasing, etc. Field sparrows, song sparrows, fox sparrows, and towhee buntings, had increased; also the blackbirds, meadow-Iarks, and the small wintering parties of whits. throats and whitecrowns had swelled to about twice their numbers. April 3 was the first fine day. The wind had changed during the night from north to southeast. No new arrivals on this day. Cowbirds were seen, but they had probably been here before in company with blackbirds. In the evening of this day (April 3) the first martins came back again (had been gone since March 18), and a rough-winged swallow. At $9: 20$ p. m., I heard distinctly the voices of wandering robins flying over the city. The sky was clear, mercury $50 \mathrm{dgs}$, and a light southeast breeze.

This night brought us numbers of birds. The first thing in the morning of the fourth was the ditty of the chippy. The van had arrived during the night. Wherever I went on the fourth there were robins and flickers, and the number of blackbirds was very great (redwings and grackles). Among the arrivals were also many golden-crowned kinglets and creepers. Also a troop of cranes passed by at $6 \mathrm{p}$. $\mathrm{m}$. The next night brought us still more birds, and the fifth of April was a glorious day.

The day had opened with a light thunder-storm, after a calm, warm night (mercury at 60 dgs.). The day was sultry, with threatening clouds and light variable winds, just the weather for birds and bird song. The night had brought the first thrashers, the Bewick's wren, and the bulk of rubies, chip)pies, towhees, more robins and flickers, etc.

The next three days were cooler, but the afternoon of the eighth was warm and the first swifts and cormorants came in advance of the new wave.

The night of April 8 was warm, with a light south wind, clear to fair. It took off the last few fox and tree sparrows, many snowbirds and song sparrows, robins and fiickers, purple fincdes, etc. It brought us clouds of yellow: rumps, the grand army of Peabodys, more swamp sparrows, white crowns, chippies, hermits, water-thrushes, gnat-catchers, and flocks of thrashers. WVe have had very warm weather since that. The thirteenth and fourteenth were lot with high southerly winds, but few arrivals were met with; the van of a few species, such as the white-eye, the eave and barn swallow, yellow redpoll, has been seen, and others have increased, especially the swifts and gnat-catchers, the snipes and yellow-rumps, and perhaps a few others. A few have disappeared, namely, the snowbirds, ruby-crowned kinglets, creepers, 
rusty blackbirds, etc. The most conspicuous birds of the present time are the yellow-rumps, Peabodys, thrashers, towhees, chippies, cow-birds, grackles, redwings, and meadow-larks. Crows, robins, phcebes, blue birds, shrikes, field-sparrows, and Carolina wrens have nests or are building; also redbirds and king-fishers. Even chippies and towhees have commenced.

April 17.--Sunday was a cool day, with a strong wést wind, but clear, and the wind subsiding in the evening. The night was clear and cool, and Monday opened with a light southwest wind, clear, with mercury at $48 \mathrm{dgs}$. It was a fine, perfect day, not too warm, but it brought only two new speciesthe house-wren and the golden-crowned thrush.

Last night was a beautiful night, almost perfectly calm, at least in the early morning, smoke going straight up, and not a cloud visible. It was so calm and clear that in (3eep places a light hoar frost was found, although my thermometer was not below 48 dgs.

It was a birds' night, and I' founcl quite a number of old friends in the wnods this morning; no migrants, but Summers sojourners, at their breeding places, on the same trees as last year; all old males in high plumage and in fine song.

April 18.-Fair weather continued; night was warm, hazy, with light sonth wind. To-day there is a brisk southwest wind, and threatening indi('ations.

April 19.-After a very dark night, and a light rain from 5 to $7 \mathrm{a}$. m., after which it was cloudy, the afternoon was clear and fine, with cool northwest wind.

April 20.-A clear, conl night, and most beautiful day. Clear and cool, with a hrisk southwest wind (had shifted during night). No change in ornis. Much the -ame birds as on the 18 th and 19 th, with additional individuals of the same species.

A pril.-The twenty-first opened 'loudy, with strong cool (55 dgs.) north1 ast wind, turning at noon to southeast with a light rain; the afternoon heing warm (70 dgs.) and in the erening, ss well as twice during the night there were thunder storms, with heary rains, but wind coutinues in the south. east, with prospect of more rain to-day.

Birls are moving, and the next few days will reveal a number of new species, und a large increase of sucl as are now represented by the advance guard only.

A pril ?4.-A cold period, preceded by : series of thunder storms set in during the twenty-third, and put a check to the movements of birds. In fact, the cold night of the trenty-third chilled all our birds so much that the bright sun of the trenty-fourth could not induce them to their usual song, and everything seemed deserted. The thrasher and chippies, so noisy before, had nothing to say, and even the uliquitous blackbirds were $n$ m est.

The next day was hetter, but still cool in the morning, and it took several hours to warm the birds up enough to give a song from time to time. During the twenty-sixth the wind changed slowly from north to south, but the next morning found it back again to north. It is cloudy, and there is not the change in our ornis that I expected.

Yesterday the wind was southwest to northwest, with dark clouds, and falling temperature. To-day is clear and bright, but cold, with strong north 
wind. Taken altogether this week, usually one of the best of the season, was very unproductive, and it required considerable search to discover a few indi. viduals of species not before seen. It must be understrod that such new arrivals are not met with the very first day after their arrival; they may be here for a number of days before they are discovered. The record of simple first dates without further observation of the species is therefore of little or no value for the study of migration.

The correctness of this opinion is confirmed by the experience of this last week. I met, for instance, the first indigo on the 21st, but I have not seen any more since that day. I have met the first Savannah sparrow and the first Lincoln's finch on the twenty-third, but none since, in spite of the most careful lookout, and frequent visiting of nesting stations of former years. I heard the song of the first Bell's vireo on the twenty-fifth, but none since, although I passed daily many of their old stands. I saw and heard the red-eyed vireo on the twenty-fifth, but only once again, on the twenty-serenth. The first Tennessee warbler was met with on the twenty-fifth, but only once again, on the twenty-seventh. In short, it requires a good deal more than first dates to get an insight into the movements of our birds. During the week sixteen new species have been seen, but all of these sixteen new arrivals did not change our ornis in the least; it required an ornithologist to discover them. But the real change in our ornis comes from the increase and prominence of a few species, the van of which came during the preceding week (18th-22d), and the bulk between the twenty- $\mathrm{ffth}$ and twenty ninth. The rose-breasted grosbeak and the Baltimore oriole are the con. spicuous and noisy birds of to-day. Females have arrived, and old males are now back in full numbers.

May 1.-Day after day I go out with the expectation of meeting friends whose arrival has long been due, according to my records of former years. But in vain. Two more days have gone by, and no north bound bird, no new species has arrived. The host of transient warblers, and some of our Summer sojourners have not yet made their appearance, and are getting more or less behind their dates of other years.

The weather has been exceedingly fine for all purposes of homo sapien. at least, especially for komo sapiens $v$ rusticus, pleasant, clear mornings, clouding over toward noon, thus keeping us from getting overheated. Dry weather and cool nights. But just this dry weather and these cool niglits, I tinink, are the cause of the retardation in the arrival of our insect-loving travelers; and, indeed, it is astonishing how free the air is from all kinds of in sects. Though it is greatly beneficial to the comfort of man, yet not swelling the reports of an observing ornithologist. Vegetation is progressing slowly but steadily, and our heautiful warblers will find abundant shelter in the thickly-foliaged maples, elms, poplars, lindens, etc, as well as the orchard trees. Even oaks and hickories have put forth half grown leaves, and are covered with catkins. Buckeyes and paw paws are in fine bloom.

We have had no hot period since the middle of April, but I think there is one approaching now. Easterly winds have.blown for several days, and if the wind should turn to the South now, we should have plenty of work. Swamp sparrows, Peabody birds, yellow rumps and yellow redpolls are still remaining with us, and are all assuming the high-colored state. When the; 
go, mark you, there will be few among them without their wedding clothes. The only change during the last few days is the great increase of the gold. finch and the black-throated bunting.

May 2.-A full bird-wave reached us last night. The night was clear and warm ( $66 \mathrm{dgs}$. to $5.5 \mathrm{dgs}$.), and the wind south. It brought us thousands of birds, and the woods are just full of them. It is impossible to observe all birds around me, especially since the capture of my first Cape May warbler (tigrina) took a part of my best time.

May 3.-Wind continued south until night, when a cool north wind set in; maximum temperature, $90 \mathrm{dgs}$. Bird life at its height. Number of species and individuals, at or very near highest of the year. All the Summer so. journers are here (with few exceptions), and most of them in full numbers.

May 4.-Weather cool, rainy, dark, with north wind. Birds and observer take a rest.

May 5.-The most beautiful day of the year, genial temperature with north west wind. I found sixty different species of birds on ten acres of ground.

May 10.-When I made my last report(May 5) I had noidea that the Spring migration would so soon be over, but, alas! All seem now to be gone.

The high south wind of the last three days (seventh, eighth and ninth), has carried away many unwritten pages of future reports.

The birds passed us without stopping. Had this cold wave which we enjoy to-day struck three days ago, we might have had a fine time. Dry, hot, high, south wind is always bad for the observer. Looking for birds in such weather is hard, unsatisfactory work. That rustle of the shaking leaves, rustles all enthusiasm out of my heart, and I go home discouraged. To find only one new species from May 6 to May 10 is enough to discourage anyone.

This one species was the inevitable yellow warbler, and I met with one male on the ninth, and again on the tenth.

In vain did I look for the tawny thrush, orange-crowned, mourning and Connecticut warblers, clay-colored sparrow, olive-sided and yellow-bellied fly-catchers.

As a whole this season was bad for this paricular part of the country. We have had almost no bird-waves because the polar wave never struck at the right time. The Savannah and Lincoln's sparrows, the pine-creeping and the bay-breasted warblers and the least fly-catcher have stopped but a moment. to be off next day. Other species seem to take other routes, being seldom or never seen here, especially the black-throatea blue, Blackburnian, blackthroated green and hemlock warblers, and the clay-colored sparrow.

Thanks to the unfavorable weather of the last four days even some of my Summer sojourners are still without dates, namely, cuckoos, hummers, and nighthawks. Others which are local have to be looked after, such as the prai rie and worm-eating warblers, the marsh wrens, whip-poor-wills, etc.

May 19.-Strange, indeed! I thought migration was over on the 10th. How great was my astonishment on the 14th to find a good old-fashioned bird-wave. The woods were full of transients, and this is how it came. May 11.-Cold with northwest wind. May 12.-Cold, with northwest wind. May 13.-Rain. with southeast wind and rising temperature, and a thunderstorm at mid. night! Next morning, the 14th, the wind was shifting to west and northwest. 
while on the 15th it continued northwest until the evening of the sixteenth, with cool nights.

The theory is that the transients were overtaken by the rainstorm of Sunday (13th) night, and kept back by the cool nights following. Since the 17th we have had warmer weather with southerly winds, and the transients have thinned out decidedly. The best days were the fourteenth, fifteenth and sixteenth. There is no doubt but some birds were suddenly stopped. Water thrushes, Lincoln's finches, yellow-bellied fly-catchers, etc., were found in a dry pasture in the city, and the short-billed marsh wren by the way. side.

May 21.-Yesterday was one of those hot days with southwind, and little could be done. Last night copious rains, to-day a sultry, threatening southwest wind. Look out for a grand move.

May 29.-Cool weather continues up to this day, but two warm nights, the 23d and 24th, have taken off all transients. Migration for this Spring is at an end. 


\section{PART III.}

\section{GENERAL NOTESON BIRDS AND IVEATHER, AT JEFFERSON, WISCONSIN, IN THE SPRING OF 1883.}

\section{W. W. COOKE.}

January 21.-Coldest day of Winter; mercury $32 \mathrm{dgs}$. below zero.

January 26.-Hail and rain in small quantities with south wind. From then on there was melium Winter weather until February 12 , it began to feel Spring-like. The next day was also pleasant; mercury at $27 \mathrm{dgs}$. with south wind.

February 14.-Commenced to thaw. South wind.

February 15.-Warm. At night heavy rain with thunder and lightning.

February 16.-Rained all day. Strong south wind.

Feluruary 22.--Slight snow, wind north, mercury at 16 dgs. Clear.

February 23 to 28 .-Constantly growing warmer, with mostly south, but not strong winds.

March 1.-South wind at 6 a. m., mercury was 27 dgs.; at 9 a. m. 36 dgs. ; at 1 p. m. 55 dgs. Snow three-fifths gone.

March 6.-Snow all gone,

March 9 to 12.-Severe northwest wind, everything frozen solid.

March 13 and 14.-Very warm with west wind, starting the waterbirds northward. Next day cold, with hard northwest wind. Winter once more and not a bird to be seen.

March 16 and 17.-Warm southwest wind.

March 18.-Cold, almost to zero. No migration whatever took place from this date until the $23 \mathrm{~d}$.

March 23.-Niglat of the twenty-third clear, barely $32 \mathrm{dgs}$. with south wind. Just the night for birls, and the morning showed quite large arrivals of snowbirds, tree sparrows robins, blackbirds and bluebirds. But Spring was not yet to come and from the 25th to evening of the 31st, the nights were cold and freezing, with northeast to northwest winds, and snow on two days. No increase in any birds.

The first of April, it began to change.

April 2-TVas a bright, beautiful Spring day, with the night before clear and still, but so cold, that no migration was perceptible. The first frogs appeared, and mud-turtles were very numerous along the river hank.

April 3-During this day preparatory moves were made by ducks and geese, and the night of the 3rd ushered in the first real wave of Spring migration. Queer weather for migration.

April 3.-This day was a mixture of snow and rain, and the night was very damp and cloudy with a warm south wind, and mercury at 40 dgs. Yet this dark, cloudy night brought the bulk of the snowbirds and tree sparrows, 
many song sparrows, the first fox sparrow, ruby-crowned kinglets, Winter wrens, kingfishers, yellow-bellied woolpeckers, white-bellied swallows, phoehes, brown creepers and hermit thrushes, besides swelling the numbers of all kinds that were here.

April 5.-A twelve hours rain to-day.

April 6.-This day brings four inches of snow. It seemed strange while walking through it the next day to find two full sets of crows' eggs.

April 8.-Changeable.

April 9.-Not Spring but Summer, with the mercury at 76 dgs. in the shade and a strong south wind with not a cloud to be seen.

A pril 10.-Another Summer day, with a slight almixture of New England weather, raining in the afternoon with the mercury at 60 deg., then the wind slowly changed from south to west, and northwest, and during the night it froze. No wonder the birds seemed discouraged this Spring.

April 12.-Bright, warm and windy, and in the afternoon cloudy. Mercury at 48 dgs. at 8 a. m. The first day this Spring that tha air has been full of song. The great change was produced principally by the bursting forth in full song of the tree sparrows, which have been gradually increasing in melody since March 23 . To day they and the song sparrows were on every bush and tree, each one striving to outdo the others.

April 13.-Warm, with a strong south wind and bright sky. Night of the 13th was warm and clear. It was our first Summer night.

April 14.-At 6 a. m. the temperature was $65 \mathrm{dgs}$, with a strong southwest wind. At 9 a. $\mathrm{m}$. the temperature was 76 dgs. and at noon a hard rain set in, and during the night of the 14th it cleared off cold.

April 14.-The first thing that struck me on reaching the woods this morning was the stillness; so different from two days before. Not one-tenth of the song sparrows were left and only four tree sparrows were seen, the scattered black birds were gone, and even the robins were much less numerous. It seemed as if all migrants, which had halted for a few days, had taken the favorable opportunity of the south wind and left for the north.

April 15.-Mercury at $42 \mathrm{dgs}$. Cold and chilly all day, with a strong west wind, bringing all the white-hellied swallows, which for a week had been ('ircling over the city, into one flock; which kept all day over one place on the river near the principal bridge, where they were somewhat sheltered from the chill wind by high hills and buildings. April 16-April 24.-The next eight clays were a succession of cold chilly nights, twice freczing; with rather clear, but not warm days. Very little migration took place, ind the general character of the birds here was unchanged. Only one new arrival was noted, the chewink, and no departure at all.

April 24-April 28.-These lays were a little better. The nights were still cold-the first two nights freezing-but the days were warmer, and bird life was more ahundant and much more active. Almost every day showed new species, though none of the really Summer birds had arrived, and the lingering snowbirds, ruby-crowns and purple finches, gave a Winter aspect to our avifauna. The first wildflower-the hepatica-opened on the trentyfourth, and the next day the îrst leaves of the earliest laurels began to show.

A pril 29-May 3.-The next week was a transition period from Spring to 
Summer. The 29th and 30th were cloudy, cold with nights a little above freezing, with north and northeast winds; but the days were quite warm. Mayday showed a few flowers, the caltha, wood anemone, claytonia, sanguinaria, rue-anemone and one crucifer in blossom; while only a few shrubs, as the currants, raspberries, box elders, etc., had put forth leaves, and they were not more than one-tenth grown. A walk in the evening showed no new species, and scarcely any change in the birds from what they were a week before. The night of the 1st it rained all night incessantly, but not hard, the wind changing after $10 \mathrm{p} . \mathrm{m}$., from south to north. In the morning we had a few hours of sunlight, and again steady rain from the afternoon of the $2 d$ until 9 a.m. of the $3 d$. Yet these two dark, stormy nights brought us our first Summer birds, and marked a distinct and decided change from Spring to Summer. They brought us the house wren and the chippy, large flocks of white-throated sparrows and blackbirds, and, at last, the warblers. Six specres were identified before a pelting rain drove me out of the woods.

May 4--The night of the $3 \mathrm{~d}$ was cold and foggy, mercury at $40 \mathrm{dgs}$., with north wind, and that of the 4th was not much better. But little movement took place, and the new birds noted-small billed water thrush, blue-yellow backed warbler, warbling vireo, etc., were in small numbers and inconspicnous.

May 5.-The afternoon was enlivened by the song of the first bobolink. A warm evening, and perfectly clear, still night, with mercury at $46 \mathrm{dgs}$.

May 6.-I expected to find that great movements had been taking place, and, indeed, considerable change was apparent, but a rain set in fifteen minutes after I left home at 6 a. m. and continued until just before I returned at 8:30 a. $\mathrm{m}$. I found the first kingbird of the season awaiting me, around the corner was the first rosebreasted grosbeak, as full of song as he could hold, and at last a atbird, nearly three weeks behind his time. White throats had noted the favorable night and left. I found only one-tenth of yesterday's numbers. In the evening there was a strong south wind, with much thunder and lightning, and a little rain; very dark. Cleared off some time in the night.

May 7.-At 4 a. m. it was clear, with southwest wind and mercury at $58 \mathrm{dgs}$. Alternately cloudy and clear all day with wind suddenly changing to north at 10 a. m. Maximum temperature $70 \mathrm{dgs}$. Not much movement of any species, but some changes in nearly all. The chippy, chimney swifts, grass finches, phobes, and martins have increased somewhat, and are in about full Summer numbers. The greatest change to-day is produced by the arrival of numbers of Baltimore orioles, rosebreasted grosbeaks, and red-headed woodpeckers, all in full voice, and the scream of the latter trying vainly to drown the beautiful melories of the other two.

May 8-May 9.-The next two days brought little, but rain with variable winds from north to south. The afternoon and evening of the 9 th the rain fell in torrents, flooding the whole country. Much of my best ground is changed to marsh.

May 10.-The rain ceased at 3 a. m., and a walk in the woods from 5:30 to $8: 30$ a. m. revealed considerable movement among the birds. The most noticeable changes were the arrival of the goldfinches in flocks, and the decided increase in the bobolinks. The females of the grosbeaks, towhees 
and Baltimore orioles, had also arrived. Also quite a small army of warblers had come the rain, bringing the first redstart, magnolia, hemlock, black poll and Nashville warblers; and at the same time the first yellow-throated and blue-headed vireos were seen, also the first tanager. A greatincrease had taken place in the kingbirds, chimney swifts, and least fly-catchers. Strange that so much change should have taken place in the face of a north wind and a very heavy rain storm!

May 11.-Night before was clear for the first time in more than two weeks; wind northwest, and moderately strong; hard frost, and froze in lowlands. I was in the woods from 6 a. m. to 8 a. m. Apparently no change whatever; bircls scarce owing to cold, and I could not stay out until it was warmer. Only noticeable thing seen was seventeen blue jays in one flock passing leisurely north through the tree tops.

May 12.-Night before clear, with strong north wind, mercury $40 \mathrm{dgs}$. The morning was beautiful, but chilly, was out all day and found bird life quite abundant, but still far from full Summer numbers.

May 13.-Night before cloudy, with $\backslash$ north wind and mercury at $40 \mathrm{dgs}$. The day was half cloudy until $2 \mathrm{p}$. $\mathrm{m}$. when it began to rain, and continued almost steadily until early the next morning. North wind and mercury at $43 \mathrm{dgs}$.

May 14.- This morning it cleared off at 5:15, mercury at 40 dgs., with a north wind still. No change of birds was apparent. The evening turned out to be bright moonlight, with mercury at 48 dgs., and a south wind.

May 16.-This day was clear with maximum temperature of $71 \mathrm{dgs}$. No new arrivals were noted, and no increase perceptible in any, but decrease or total absence of some told that the night's favorable opportunity had been utilized. A decided decrease was apparent in all Hylocichlae.

May 17.-Night before was moonlight, warm and clear with south wind. Just such a night as birds most like for migrating. Yet, although some movement was apparent, it was not great.

May 18.-Night before cloudy with south wind, and from daybreak the mercury rose rapidly. The day was hot, sultry and cloudy, with a strong south wind from 9 a. m. to $2: 30 \mathrm{p} . \mathrm{m}$. The thermometer marked $82 \mathrm{dgs}$. in spite of the clouds. At 3 p. m., a regular cyclone of the Iowa kind advanced straight toward us until it reached the brow of the hill a mile and a half west, when it split and the two parts passed north and south of us, and destroyed two neighboring towns. Evening and night warm and rainy, the strong south wind still continuing. I was not in the woods at all on the $18 \mathrm{th}$, but either on the night of the 17th or 18th there must have been much migration, as I found great changes when reaching the woods on the 19 th.

May 19.-This day can be set down as the height of the season for birds at this place, but yet so many of the transients had already passed northward that, although the woods were full to overflowing with song, the most of the melody came from a few birds. The redstarts furnished a large part of the music, and the rest of the choir was composed principally of vireos and flycatchers. With this day terminated most of the work in migration for this Spring. It was the grand swell of the migratory wave just before its final subsiclence. The arrival of only six birds remained to be chronicled, and the 
next few days were so cold, cloudy and disagreeable that the departure of the transients still remaining was slow and hardly noticeable.

May 20-May 23.-These days were cloudy and rainy with wind shifting from west to north and northeast, and the mercury hanging around $40 \mathrm{dgs}$., with a fall, twice, to $32 \mathrm{dgs}$.

May 24.-After a hard rain the night before, we again had Spring weather and a bright, clear day. It showed the last arrival of the season of the Summer sojourners, the cuckoos, which usually bring up very near the end of the list; and it also showed the tawny and olive-backed thrushes as numerous as any time this Spring.

But little remains to be chronicled of this Spring's migration. The last transient visitors, the Connecticut and the Canadian fly-catching warblers, put in their appearance on the 26th; after a four days' visit, left us on the 29th, taking with them nearly all the remaining transients; and when the last olive-back departed on the last day of May, migration was ended. 


\section{PART IV.}

NOTES ON EACH SPECIES OF BIRD OBSERVED AT ST. LOUIS, IISSOURI, AND JEFFERSON, WISCONSIN, DURING THE SPRING MIGRATION OF 1883.

Wood Thrush (Hylocichla mustelina). St. Louis-Summer sojourner. The first seen was on April 19, when two were found at old stands singing a few strains, when it began to rain. April 22, two were in full song. April 29 they were still quiet and scarce. May 1. They are exercising every morning now, and by the 16th had become conspicuous and diligent songsters.Jefferson-Summer sojourner. First one was seen on May 10, and by the 12th there had been a decided increase and many were heard and six or eight seen; the bulk of the birds have not yet arrived. May 17. This day marked the height of the migration, and by the 21st they had settled down to Summer numbers.

Wilson's Thrush (H. fuscescens). St. Louis-Transient. First seen on May 14 , and were numerous on the 15th, 16th and 17th. On the 21st several were seen and they were the last.-Jefferson-Transient. First seen on May 7. May 12 the bulk of the birds were with us, but they were gone a very few days later, and only one was seen on the 21st, which I supposed was the last, but on the 24th they were as numerous as at any time this Spring. The last one seen was on May 30.

Gray-cheeked Thrush (II. alicice). St. Louis-Transient. Last seen on May 22. Jefferson-transient. Only identified on May 24.

Olive-backed Thrush (H. ustulata swainsoni). St. Louis-Transient. First one seen on April 26 and no more until May 2 when the bulk arrived. On the 5th was the height of the migration. Were still present on the $10 \mathrm{th}$, and from the 14th to 18 th quite numerous. Last one seen on May 24. Jefferson - Transient. Have lost my record of the first one, but a second was seen on May 3. On the 12th I met with the tawny thrush quite often; about the height of the migration. During the next week the bulk departed, and on the 19 th only three were seen. On the 24 th they were as numerous as at any time this Spring. Last seen on May 31.

Hermit Thrush (H. unalasce pallasi). St. Louis-Transient. First seen on April 9, and from the 10th to the 12th was the height of the migration. Last seen on April 13. Jefferson-Transient. First one seen on April 4; another seen on the 5th, which I shot. One or more seen nearly every day until the 20th, when they began to be more common. On May 6 the bulk departed and the last one was seen on May 10.

Robin (Merula migratoria). St. Louis̄.-Summer sojourner. First seen on February 22 when there were about thirty in a flock in a wood. On March 4 , several small flocks were seen at different places, but the bulk had not yet 
come. On the 11th they were still scarce and first song was heard on the 8th. March 14, numbers were feeding on soft ground in company with blackbirds and flickers, and on the 16th were found on the prairie at their old stands and in two small flocks, but not numerous and noisy. April 3, at $9: 20 \mathrm{p}$. m. the voices of wandering robins were distinctly heard flying over the city. Wherever I went on the 4 th I found robins. Height of the transient visitation April 4 to 8 . Jefferson.-Summer sojourner. First bircl seen on March 1, and no more until the 14th, and then only two. On the 17th I saw the first flock, about thirteen. No migration of any kind from then until March 23, after which they very slowly increased. The only large flock seen this Spring was on April 6. The height of song and of numbers was on April 12, when single ones and pairs were seen everywhere: but two days later all the transients had apparently left. The first egg was found on April 27.

Mocking bird (M. polyglottus). St. Louis.-Summer resident. On New Year's day three were seen. April 16 I heard the first song, and on the 17th two more songsters. May 1. Ranks are filling up slowly as usual.-Jefferson. Does not occur here except as a straggler.

Catbird (G. carolinensis). St. Louis.-Summer sojourner. First one seen on April 18, which was in high plumage, but silent. April 22. A slight increase and singing a little. April 29. Still comparatively quiet and scarce. May 1. Still scarce. A morning's walk reveals less than half a dozen. May 2. The bulk of the birds arrived to-day and many migrating flocks and many more came during the following night. May 14. Found the first set of eggs, and on the 16 th many diligent and conspicuous songsters. Jefferson.-Summer sojourner. May 6 first saw three, nearly three weeks behind time. On the 7th they had increased greatly; probably twenty per cent. are here, and they are very noisy. May 10. The bulk of the birds. May 12 to 19 . Height of the migration.

Brown Thrush (H. rufus). St. Louis.-Summer sojourner. First seen on April 5. Bulk on the 9th and the height of the migration from 9th to 16th. Jefferson.-Summer sojourner. First seen on April 25. For some reason this immediate vicinity is disliked and shunned by this species. After the first one, which was seen again the next day, no more were seen until May 3 and 4 , one on each day; and on the 6 th five more were seen. This last date might be called the height of the migration for this place, as at no other time have I seen more than three a day and two-thirds of the time none at all, though in the woods all day long.

Bluebird (S. sialis). St. Louis.-Summer resident. In January these were first seen but only single birds, no flocks. February 13. Birds are mating, and up to the 24th were a great many arrivals; about half the birds seem to be back, being in pairs or pairing. March 4. The bluebirds were the chief birds of the past week. They were seen and heard everywhere; the males doing most of the warbling; the females most of the fighting. I caught two females in my hands, which had come down to the ground in combat. Jefferson.-Summer sojourner. On March 11 four were seen for the first time, slowly increased from that date on. Some were paired wne they arrived, the rest mated as soon as they came. March 1\%. They began to be quite common, but the cold put a stop to all migration until the 23d, after which they have been quite numerous. April 9. They are now to be 
seen and heard everywhere in pairs, there being no flocks at all. I have not seen more than four birds ingether any time during this Spring.

Blue-gray Gnat-catcher ( $P$. corrulea). St. Louis-Summer sojourner. First seen on April 9. Bulk came on the 14th. April 1\%-Pairs continually seen in the woods, and singing. Jefferson,-Does not occur.

Ruby-crowned Kinglet. (R. calendula) St. Louis.-Transient. First seen on April 4. Height of the migration from the 4th to 12th. April 17 only two seen. April 27.-Still present. May 1.-One pair seen, and on the 3d the last bird. Jefferson.-Transient. On April 11 first saw a flock of seven, of which three were singing, and exactly imitating the song of the Winter wren. April 13.-Height of the migration, and on the 14th or 15th the bulk departed. On April 28 I visited a tamarac swamp, three miles from here, where I found the ruby-crowns in their glory. The swamp was full of them. I counted twenty-three in front of me at one time, and the rest of the swamp seemed to be just as full of them. As this was only one of many such swamps within a mile, their united number must have been very great. All were in song, and very active. April 26 the first female was seen, and from then on the number without the red crests increased very rapidly, until on May 3, though still quite numerous, not more than ten per cent. had a red crown, and the next day, out of eighteen or twenty, not one had an ornamental topknot. At 11 p. $\mathrm{m}$. on May 5 , one came to my window and tried to get in, acting as if attracted by the light, or frightened by the thunder and lightning of the approaching storm. May \%.-Nearly all gone; saw only seven. May 12. -About one-fourth as many in tamaracs as on the 5th. May 21.-Last regular visitor seen, though a straggler was seen on the 28 th.

Golden-crowned Kinglet ( $R$. satrapa) St. Louis.-Winter visitant and transient. January 6.-Two pairswere seen in different places, and no more were seen until March 1, when two pairs were found in the same places. April 4. -First of transients, and on the 10th the last. Jefferson.-Transient. April 4.-Five first seen in one piece of woods. On the 9 th they were more numer. olls, and on the 10th migration was at its height, to every mile I traveled there averaged eight birds. On April 12 the bulk of the birds departed, and from the 14 th to the 26th I occasionally saw one or two at a time. The last was seen on April 26.

Tufted Titmouse ( $L$. bicolor) St. Louis-Resident. January 1 they were too numerous to count, generally in family groups of six or eight birds, and conspicuous in every grove. It is a true resident. Jefferson.-Does not occur.

Black-capped Chickadee ( $P$. atricapillus). Resident at both St. Louis and Jefferson.

White-bellied Nuthatch (S. carolinensis). Resident at both St. Louis and Jefferson.

Red-bellied Nuthatch (S. canadensis). Not noticed at either St. Louis or Jefferson.

Brown Creeper (C. frumiliaris rufa). St. Louis-Transient, and occasional Winter visitant. On January 6 one bird was seen, and no more until February 19, when a second was seen in a cemetery, and also on March 1 and 16. On April 4 the bulk of the birds were seen, and from the fifth to the ninth was the height of the migration. The last one was seen on April 9. 
Jefferson-Transient. On April 4 the first two were seen. The bulk of the birds departed about April 11. The last one was seen April 15.

Carolina Wren (T. ludovicianus). St. Louis.-A true resident. On sunny days its call is often heard ringing through the woods. April 15 they had nests or were building. Jefferson.-Does not occur.

Bewick's Wren (T. bewicki). St. Louis.-Summer sojourner. First seen on April 5, and on the 1\%th they were in full numbers and very noisy. Jefferson.-Not seen.

House Wren (T. cedon). St. Louis.-Summer sojourner. I saw several for the first time on April 17 and again on the next day. April 22 showed an in crease, and by the 29th they were industrious songsters and mating. Jefferson.-Summer sojourner. I first saw one on May 2, when it was singing with spirit and perseverance. It was joined two days later by another, and on the 6 th two more came, and on the 7 th still more, but yet very few. On the 10 th they were still increasing slowly, and by the 12 th no more came, and the Sum. mer number was here. Not more than ten pairs about town.

Winter Wren (A. troglodytes hyemalis). St. Louis.-Transient. Once seen on April 3. Jefferson.-Transient. First one seen in a marshy wood on April 4, and on the 28th three more were seen. May 12.-One was seen in the tamarac, and was probably very near the last.

Long.billed Marsh Wren ( $T$. palustris). St. Louis.-Not seen. Jefferson.Summer sojourner. First seen on May 21, but it may have come sooner, as it occurs only locally and must be sought.

Short-billed Marsh Wren (C. stellaris). St. Louis.-First one seen on May 16. Jefferson.-Undoubtedly occurs like the preceding, but was not seen.

Black and White Creeper ( $M$. varia). St. Louis.-Summer sojourner. First one seen in migration on April 29. May 3.--Singing at their old stands. Jefferson.-Summer sojourner. May 3.-I first saw five at as many different places, but not singing. On the 5th single ones would be seen every few minutes, and on the 6th six or eight were seen. May 12.-Migration was at its height, and no apparent change after this.

Prothonotary Warbler (P. citreu). St. Louis.-Summer sojourner. On April 20 I first found six at old stands and in song, and on May 2 they were mating. Jefferson.-Not seen; probably does not occur.

Worm-eating Warbler (H. vermivorus). St. Louis-Summer sojourner. Breeding-place not visited until May 22, when a nest with incubated eggs was found by Mr. H. K. Coale, and female shot. Jefferson-Does not occur.

Blue-winged Yellow Warbler (H.pinus). St. Louis-Summer sojourner. First saw few in song on April 17. May 3, height of migration.-JeffersonProbably seen twice, but not certainly identified.

Golden-winged Warbler (H. chrysoptera). St. Louis-Summer sojourner. On May 2 I first saw a fine male in song, and on the 14th and 15th four birds, both male and female. Jefferson-Probably occurs, but not seen.

Nashville Warbler (H. ruficapilla). St. Louis-Transient. May 2.-First saw a fine male in song, and on the $3 \mathrm{~d}$ six were seen, and these were the last.-Jefferson--Transient. On May 10, first saw two males and saw only fire up to May 12. No more seen until on May 22, a pariy of six or eight. May 26.-Last one seen.

Orange-crowned Warbler $(H$. celutu). Undoubtedly a few pass through 
each place in the Spring, but none were seen at either St. Louis or Jefferson.

Tennessee Warbler ( $H$. peregrina). St. Louis-Transient. First seen on April 25, and again on the 27th, a single individual in song. On May 2 numbers were seen and heard, and on the $3 d$ was the height of the migration, which continued up to the 10th, and they were still numerous up to May 18. Last one was seen on May 24. Jefferson-Transient. First one seen May 17. May 19.--No males seen yet this year; females three times. May 22.-First saw six or eight single males, and they were the last seen.

Blue Yellow-backed Warbler. ( $P$. americana). St. Louis-Summer sojourner. On April 17 first saw several in song. Jefferson-Summer so. journer. First saw one or two in heavy timber on May 4, and on the 12th only a few were here, after which none were seen.

Cape May Warbler (P. tigrina). St. Louis-Transient. On May 2 first saw a fine male in song. Jefferson-Not seen.

Summer Yellow Bird ( $D$. astiva). St. Louis-Summer sojourner. First saw"three on April 18, singing at old stands, and by the 19th many were in song. On the $22 \mathrm{~d}$ of April there was a decided increase, and by the 29th they were mating, and were industrious songsters. May 1.-Numbers of singing males are here, and probably many individuals in transit among them. This species has not yet attained that state of excitement which is incident to mating when the females arrive in bulk. May 5.-Their numbers have decreased owing to the departure of the transients. On the 1 17th nests were found. Jefferson-Summer sojourner. On May 7 first saw about a dozen males in as many places, and very noisy. May 8.-More numerous, and on the 17th was the height of the migration. May 19.-Full Sumner num. bers; nesting.

Black-throated Blue Warbler (D. cœrulescens). St. Louis-Transient. Never seen in Spring, but once seen in Fall. Jefferson-Transient. On May 3 I first saw a beautiful specimen in the evergreens in my yard. It was not mo. lested, and remained around for five or six days, and became quite unmindful of our presence. This was the first and only one seen until May 10, and on the 12th, although they were not numerous, still it was about the height. May 15.-Two were seen, and on the 17th the last one.

Yellow-rumped Warbler (D. coronata). St. Louis-Winter and transient visitor. On January 1 two flocks were seen ten and twenty-two birds respectively, most of which did not stay through the Winter, though a few did. On February 19, in an old graveyard, which has a fine growth of several kinds of evergreens, I found a flock of fifteen, which had probably spent the hardest part of the Winter there; their characteristic, loud "cheek" was continually heard. In the wood, which was populated by a flock on December 28, only one was found on February 22, but the chief attraction for them, the berries of the poison ivy, and which at the former date were quite abundant, were at the latter date all gone. The first of the transients came March 22, and the night of April 8 brought clouds of them. April 13 and 14 migration was at its height, and on the 17th but fow were seen. April 18.-About thirty were found in four places. April 21.-Very numerous; in large flocks on the Illinois side of the Mississippi, and the same on April 29. On May 2 the bulk departed, and on the 5th the last one was seen. Jefferson-Tran. sient. On April 11, as usual, this was the first warbler seen, and, strange to 
say, it was a female. No more were seen until April 25, when there appeared three males in high plumage, and no more until May 2, when a flock of five were seen in the city. Previous to May 2 yellow rumps and pine creeping warblers were the only warblers seen, and only nine individuals in all, while at the same date they appeared at St. Louis. The night of May 1 marked the first wave of warblers, and on the $3 d$ I found a flock of about twenty-five yellow rumps, both male and female, and in loud song. May 4.- Yellow rumps are at this date the most numerous of the warblers; about twenty-five to thirty in twos and threes. About four-fifths were males in full plumage. May 5.-None were seen, but on the 6th about eighteen. May 7.-Males of last year are here; most old males have gone. May 12.--Bulk departed, and on the 17th the last one was seen.

Black and Yellow Warbler (D. maculosa). St. Louis-Transient. First seen on May 3, when they were numerous and singing, and on the 10th they were still here. May 14 to 17 . Both males and females were numerous, and on the 21st the last one was seen. Jefferson-Transient. First saw three males on May 10, and on the 12th the bulk of the lirds were here and the migration was at its height; they were the most numerous warbler of this date. May 20-Two were seen, and on the 28th the last one.

Cerulean Warbler $(D$. cceruleat). St. Louis-Summer sojourner. First seen on April 17. Jefferson-Not seen.

Chestnut-sided Warbler (D. pennsylvanica). St. Louis-Transient. On April 27 first saw an old male in song, and again on May 2 and May 10. May 11, 14 and 15, both males and females were numerous. On May 21 I found a female singing! May 24-Last one seen. Jefferson-Summer sojourner. On May 7 first saw three or four in a miscellaneous flock of warblers. May 12 -Not quite the bulk of the species, but on the 17th there was the bulk of the females, and the height of the migration. May 19-Bulk departed; but six or eight seen, all males. Only a few remain to nest, I think about four to six pairs in the same number of square miles about here. One nest was found, and the birds seen through the whole month of June.

Bay-breasted Warbler (D. castrnea). St. Louis.-Transient. On May 3 first saw a male, which was silent. May 21-Last seen of both male and female. Jefferson-Not seen.

Black-poll Warbler (D. striata). St. Louis-Transient. On May 2 first saw one male and heard several. On May 3 the first female was seen and many males were singing after $11 \mathrm{a} . \mathrm{m}$. May 10.-Still here, and from the 15 th to the 18th both male and female were numerous. May 24.-Last one seen. Jefferson-Transient. On May 10 first saw one male. 17th, the bulk was here. May 19. None seen. May 21.-First female, which was the last of the species seen.

Blackburnian Warbler (D. blackburnice). St. Louis.-Not seen. YeffersonTransient. First saw two males on May 10, and on the 12th was the height of the migration, though there were very few. May 16.-One was seen, and on the 17th the last one.

Yellow-throated Warbler (D. dominica). St. Louis-Summer sojourner. First seen April 12. On April 18 three males were seen on high trees, and on the 19 th many were in song. Jefferson-Does not occur.

Black-throited Green Warbler (D. virens). St. Louis. Not seen. Jeffer- 
son-Transient. On May 5 first saw one male. May 12.-No males seen but several females; only two males seen this Spring. May 19.-None seen, and last one probably left about that time.

Pine-creeping Warbler (D. pinus). St. Louis-On April 21 first saw one male among yellow-rumps and red-polls. Jefferson. On April 24, at six 1). m. I shot a male, which had been very lively in the top of an oak; its stomach was full of insects and it was quite fat. Saw no more until May 3, when there came a large flock of about fifty or sixty, both male and female. They showed their creeping babits very plainly, but sometimes flew to the ground among the red-polls. They were the most numerous warblers of this date, and were the last that I certainly identified, though think I saw some young birds or females on May 19, which is about the time the last of the migrants should be seen. So far as I know they are transient, though generally supposed to breed as far south as this.

Red-poll warbler (D. palmarum). St. Louis-Transient. On April 13 first saw one bird among some yellow-rumps. April 19.-Many in song, and on the 20th they were still more numerous, and on the 21 st about equal in num. ber to the yellow-rumps, with which they frequented the willow thickets and watercourses. On April 29 they were still numerous, but by May 2 the bulk had departed and only a few were seen. May 5.-Last one was seen. Jefferson-Transient. On May 3 first saw about forty males and females; silent and continually on the ground as usual. May 4--Saw about six parties of from three to five each, and on the 5th three or four more groups of twenty or twenty-five birds in all. May 7.-About the same, with a slight decrease, if anything. May 10.-Two seen, which were the last.

Prairie Warbler (D. discolor). St. Louis-Summer sojourner (local). First seen on May 22, when I, for the first time, visited their breeding grounds, which are about ten miles from the city limits. Jefferson-Does not occur.

Golden-crowned Thrush (S. auricapillus). St. Louis-Summer soiourner. First seen on April 17, when they were numerous; old males in full numbers and noisy until 10 a. m. May 15-Three eggs. Jefferson-Summer sojourner. On April $28 \mathrm{I}$ found the first ones in a tamarac swamp; they were in full song. First seen in hardwood timber were three on May 3, and no more until the 11th, and then only one. May 12-Numerous and about the bulk. On May 19 they were as numerous as at any time, and continued the same thereafter.

Small-billed Water Thrush (S. nrevius). St. Louis-Transient. On April 21 first saw one male in a slough; it was silent. May 2-Had increased, and it was about the height of the migration; they were in song. May 5-The height still continued and was present up to the 10th. May 14 to 17 -Still numerous, but the last was seen on the 21st. Jefferson-Summer sojourner. First one seen on May 2. The bulk of the birds were here on the 12th, and the height of the migration was on the 19th.

Large-billed Water Thrush (S. motacilla). St. Louis--Summer sojourner. First seen on April 9. May 15-I found young in nest. Jefferson-May occur, but not seen.

Connecticut Warbler (O. agilis). St. Louis-Transient. First saw one bird on May 14 and again on the 18th. Last one seen on May 24. Jefferson- 
Transient. First saw one male on May 26 and a second on the 27th, and twice thereafter. Last seen on May 29.

Kentucky Warbler (O. formosa). St Louis--Summer sojourner. First seen on May 2, and the bulk of the hirds were here on May 3. Jefferson-not seen.

Mourning Warbler ( $F$. philadelphiı). St. Louis-Transient. On May 16 first saw one bird. Jefferson-Summer sojourner. On May 19 first saw one male, and another on the 21st.-May 25-Twice'seen. June 1-Has been seen about a dozen times this Spring.

Maryland Yellow-throat (G. trichres). St. Louis-Summer sojourner. On April 17 I heard five males for the first time. April 18-Saw sixteen males, which were noisy until $8 \mathrm{a} . \mathrm{m}$. May 1-Numbers of singing males were here, but probably many individuals in transit among them. On May 5 their numbers were decreased by the departure of the transients. Jefferson-Summer sojourner. On May 12 first saw one male, and again on the 16 th and 21st. No more than three seen in any one day this Spring.

Yellow-breasted Chat (1.virens). St. Louis-Summer sojourner. On April 23 first saw this species, and both saw and heard it every day thereafter. April 26-About one-fourth are present now, both male and female, and on the 29th were still quite scarce. May 2 and 3-The bulk of the birds were here. Jefferson-Summer sojourner. On May 19 first saw one male, which I shot; a second was seen on the 21st, and was twice heard later in the season.

Hooded Warbler ( $\boldsymbol{M}$. mitratus). St. Louis-Summer sojourner. First seen, one in song on April 17. On May 2 they were mating. Jefferson-Not seen and probably does not occur.

Black-capped Yellow Warbler (.M. pusillus). St. Louis-Transient. First saw one male on May 9, and again on the 10th, one male. May 11, 14 to 18. They were numerous, both male and female. May 21.-Last one was seen. Jefferson-Transient. On May 12 but one was seen, and it was skulking in some windfalls. No more until May 20, when the first flock was seen. Sereral were seen on May 21 and aud again on the 23d. May 29.-Last one seen.

Canadian Fly-catching Warbler ( $M$. canadensis). St. Louis-Transient. First seen on May 14, when they were numerous, also on the 15th and 16 th. May 24.-Last one seen. Jefferson-Transient. First one seen on May 26 and again on the $2 \%$ th, 28 th and 29 th, which was also the last one.

Redstart (3. meticillı). St. Louis-Summer sojourner. First saw one in song on April 1\%, and on the 29th it was very conspicuous in the woods, both old males and females; no young males yet. May 2.-Dozens were met with, and first males of last year, but by the 5th they were decreased by the departure of the transients. Nest found on May 17. Jefferson-Summer sojourner. On May 10 first saw five males and two females. On the 12th the bulk of the birls were here, but it was not the height of the migration; both males and females, about six of the formel to one of the latter. May 17.-The bulk of the females were here, and it was the height of the migration for the species. May 19.--As numerous as all the other warblers together; mated, mating and nesting; everywhere in the woods. Saw between two and three hundred, both male and female, in about even numbers. May 22.--Bulk of the transients departed. 
Red-eyed Vireo ( $\boldsymbol{V}$. olivucen). St. Louis-Summer sojourner. On April 2.j first saw a single individual in song, and again on the 2\%th. May 2 and 3.- The bulk of the birds were here. Jefferson--Summer sojourner. On May 19 first saw several, but probably came several days previous. About the height of the migration after May 25.

Philatelphia Vireo( $V$. Phitulelphict). St. Louis-Transient. First seen on May 21, and the last on May 22. Jefferson-Not seen.

Warbling Vireo ( $V$. gitua). St. Louis-Summer sojourner. On April 18 first saw two singing at old stands. April 22.-Have increased and are regularly heard, and by the 20th they were mating, and were industrious songsters. May 1-Height of the migration. Jefferson.-Summer sojourner. Was the first vireo of the season, and came on MIay 5, when four single ones were seen it as many widely separated places; all in full song. May 6.-Quite an increase; heard in about a dozen places, and on the 7th they were much the same with a few additions. Nay 12.-The height of the season; forty to fifty seen during the day. May 19.-The height still continued with much song.

Yellow.throated Vireo (L. fluvifrons). St. Louis-Summer sojourner. First seen on April 16; in song. May 1.-Height of the season. Jefferson-Summer sojourner. First saw one on May 10. May 12.-Height of the season, but the bulk departed during the next week Saw one on May 19, and another on the $23 \mathrm{~d}$, which was the last one noted, though it probably breeds in favorable localities.

Blue-headed Vireo (L. solitrrius). St. Louis-Transient. First saw one on May 5, which was silent, and again on the 11th, one bird. Jefferson-Sum. mer sojourner. First saw five on May 10, also on the 12th, a few, and on the 19th, three or four.

White-eyed Vireo( $V$. noveboracensis). St. Louis-Summer sojourner. On April 14 first saw one bird at old stands, and on the 17th, several. May 1.Only about nne-half regular number here; but on the $3 \mathrm{~d}$ they were in full numbers, and on the 15 th a nest containing four fresh eggs was found. Jefferson.-Certainly nccurs, but not identified.

Bell's Vireo ( $V$. belli). St. Louis-Summer sojourner. First seen on April 25, and not again until after May 1. On May 5 they had increased, and on the 11 th the males were singing about seventeen times a minute. May 15.-Full numbers. Jefferson-Probably does not occur.

Loggerhead Shrike (L. Ludociciunus). St. Louis-Summer resident. None seen between December 30 and February 23. March 14.-A migrating shrike was seen to fly north at 11 a. m., going in a straight line as far as my glass could reach him. It is seldom that we see small birds on their way migrating. On April 15 I found a nest, and on May 26 fledged young. Jefferson - Summer resident. Twice seen fluring the Winter, and at one time I saw it catch and kill an English sparrow.

Cedar Wax-wing (A. cedrom on April 9 and 12, in flocks. Jefferson-Summer sojourner. On May 10 first saw a flock of about twenty. Strange they should not have come earlier. May 17.-A second flock was seen, and by the 19th they had become more common, one or more flocks being seen every day. May 21,-First arrivals have passed on, and no more have come to take their place. 
Purple Martín (P.subis). St. Louis-Summer sojourner. First saw four at 2 p. m. on March 18. In the evening of April 3 the first martins came back again; none had been seen since March 18. April 29.--They have steadily increased, and the birds of last year have begun to arrive. The bulk came day before yesterday, but it is not yet the height of the season. May 1.-Not yet the height of the season. June 16.-Twenty-two pairs have taken boxes in my yard, and one old pair is already feeding young, while the birds of last year continued to arrive, mate and build until June 4. Their arrival this year, not counting the scouts of March 18, may be said to cover a period of two months from April 3 to first week in June. Jefferson-Summer sojourner. First seen on April 8, after which they steadily increased, and about April 27 were in full numbers.

Cliff Swallow (P. lunifrons). St. Louis-Summer sojourner. First seen on April 14, and by the 29th had increased, but were not in full numbers. May 1.-About one-fourth here. May 3.-Bulk at colowies. Jefferson-Sum. mer sojourner. First saw one on April 4, but no more until the 24th when a second one appeared. April 28.-For the first time are common, and the bulk of the species is here. By May 7 most of the migrants had left and they were in about Summer numbers.

Barn Swallow $(\boldsymbol{H}$. erythrogastra). St. Louis-Summer sojourner. First seen on April 14. Jefferson-Summer sojourner. First saw one on April 27 and on May 9, though more had arrived, they were still quite scarce. In the evening of May 11 the bulk arrived, but it was not yet the height of the season. May 19.-In full Summer numbers, but not very common here; probably about ten or twelve pairs in the square mile upon which the town is situated

White-bellied Swallow $(T$. bicolor $)$. St. Louis-Summer sojourner. The first I saw was a migrating party on April 26. Jefferson-Summer sojourner. On April 14 first saw three flying and circling over the Rock River at $3 \mathrm{p}$. $\mathrm{m}$.; did not see any in the early part of the day, although I was out all the forenoon. By April 17 four more had come, and on the 9th they were still more numerous, The height of the season was about April 26. May 8.Have nearly all gone in the last two days. May 8.-Quite a large flock arrived last night. June 1.-They were seen every day.

Bank Swallow (C. riparia). St. Louis-Summer sojourner. On April 21 first saw a party of seven going north along shore. May 1.-Have seen none since. May 3.-Bulk at colonies. Jefferson-Summer sojourner. On May 5 first saw three. May \%.-About three-tenths are here.

Rough-winged Swallow (S. serripennis). St. Louis-Summer sojourner. First seen on April 3 and again on the 17th in pairs, at stands. Jefferson-Not identified.

Scarlet Tanager (P. rubra). St. Louis-Summer sojourner. On April 27 saw one male at old stand and again on May 2. On May 3 I found one female and three males at usual stands, in song. Jefferson-Summer sojourner. First saw one male on May 11 and again on the 12th. They about doubled in numbers during the night of May 16, and the first female was seen on the 19th, when the males also were a little more numerous. June 1.-Young males have come, but no building yet.

Summer Red-bird ( $P$. cestiva). St. Louis-Summer sojourner. On April 26 first saw one male at old stand. Jefferson-Does not occur. 
Evening grosbeak ( $H$. vespertina). St. Louis-Not seen, Jefferson-Winter visitant. On March 1 I killed a male and female, the first I ever saw in Wisconsin, during twelve years of hunting.

Purple Finch (C.purpureus). St Louis-Winter visitant. From January 24 to February 14, very numerous. February 24-Have been very scarce, only two seen. March 2-Two at an old stand (one in brown); singing. March 11-Almost all gone, but on the 13th there were several new arrivals in three places. On March $16 \mathrm{I}$ found them in small parties in five places and all singing beautifully, something like the warbling vireo, and on the 17th they were still numerous and in song. April 3 to 7 -The height of the season, but on the 8th the bulk departed. April 17-Still present, but silent, on high trees and in plain dress. On April $18 \mathrm{I}$ saw four small parties in song, and the last one was seen on April 25. Jefferson-Transient. On April 1 first saw one male in fine plumage. Singing, but not in full melody. On April 4 I saw the first flock-three moles and two females. April 11-Saw two males and one female; no more until April 28, when five males and two femaies were seen. May 2-A flock of twenty; was met in the height of their wedding attire; six or eight much duller and the rest with no "purple." May 6-Bulk departed and last one seen.

White-winged Cross-bill (L. leucoptera). St. Louis-Not seen. JeffersonWinter visitant. On April 3 first saw a single female in my yard eating apple seeds.

Common Red-poll (A. linaria). St. Louis-Winter visitant. Saw a flock of thirty to thirty-six on February 12. Jefferson-Winter visitant, though chiefly transient. Occasionally seen during the Winter, but most of them left during the cold time in January. The first flocks came back again March 14, and the last was seen March 24.

American Goldfinch (A. tristis). St. Louis-Summer resident. A few were seen on January 1 , but by February 3 it was too cold for them and they almost all lefr. February 12-In a nine miles' walk saw only two birds, while in the same places four flocks were seen on January 29. March 16-Are beginning to come back, and were found in four places; a few birds only and in plain dress. A song once heard. On April 15 they were still scarce, and on the 18 th single calls were heard in six places. April 20-More conspicuous, and on the 21st was seen a flock of about twenty with the males in full Summer dress. On April 29 they had begun to be quite numerous, and by May 1 were everywhere and could be found in large flocks on high trees orer the water. Such companies make so much noise that the song of other birds is drowned. They are much like blackbirds; all the voices stop suddenly for a moment. May 11-Height continues, but by the 15 th they had decreased. Jefferson-Summer sojourner. May 10-First arrived in flocks; thirty to forty birds seen. May 12-Not quite the bulk. May 19-Numerous, but not the height; heard almost constantly and still in flocks.

Pine Goldfinch (C. pinus). St. Louis-Winter visitant. One bird seen on January 18. Jefferson-Winter visitant, transient and possibly Summer sojourner. A small flock remained about the apple trees in my yard nearly all Winter; in early Spring they slightly increased, and were very tame, allowing us to pass within five or six feet of them. They spent the most of their time upon the ground under the pines. They gradually disappeared, 
and the last one was noted on April 5. However, on May 19 I shot a male of this species, and in the latter part of May small flocks were again seen, and all through the month of June they were quite common.

Snow Bunting (P. mivalis.) St. Louis-Not seen. Jefferson-Winter visitant. Seen only twice last winter.

Lapland longspur (C. lapponicus.) St. Louis-Winter visitant. On January 6 I saw a flock of thousands; none others seen. Jefferson-Not seen.

Savanna Sparrow (P. sandwichensis suvanna). St. Louis-Transient. First seen on April 23 and not met with again. May 2.-Are strangely missing. Jefferson-Summer sojourner, On May 17 first saw one pair, which probably came several days before. They were heard again on May 19, and these were the only times they were noted this year.

Grass Finch (P. gramineus). St. Louis-Transient. First seen on April 1\%. Jefferson-Summer sojourner. On April 12 first saw about forty, all of which came during the prerious night. They are full of song; mating and fighting. April 14-Only half a dozen seen. Not much change from this date until May 5, on which day quite an increase was apparent, and on the 6th they were in about Summer numbers. They are not very common for the species.

Yellow-winged Sparrow ( $C$. presserinus). St. Louis-Summer sojourner. On April 26 first saw several at old stands and others on April 27. JeffersonNot seen.

Lark Finch (C. grammica). St. Louis-Summer sojourner. First seen on April 3, and by the 29th was one of the prominent songsters of the roadside. Jefferson-Summer sojourner. On April 27 first saw two pairs. May 12They are quite scarce, haring been seen only six or eight times this Spring.

White-crowned Sparrow (Z. leucophrys). St. Louis--Winter and transient visitor. On January I saw single birds; the same number remained in the same places during December, January and February; probably were the same individuals. March 2-About a dozen among a flock of a hundred tree sparrors, all in song, and disposed to remain among the higher branches of the trees. March 16-Still few and no increase. By March 30 the small wintering parties laad about doubled in number. First flock of transients were seen on April 14, and again on the 18th, three very noisy flocks. April 2!)--Often met with, but not in large flocks. Bulk departed on May 2, and the last was marked for May 5, nevertheless there were a few here on May 15 and 16. Jefferson-Transient. Probably seen on April 25, but not identi. fied until later. May 5-Height of the season. They were not very plentiful this Spring, and the last was seen about May 10.

White-throated sparrow (Z. relbicollis). St Louis-Winter and transient visitor. Occurred during the winter, and to April 1 in parties of six to ten in old stands. The night of April 8 brought us the grand army of Peabodys. On April 20 they were still numerous, ar il on the 21 st very numerous, and coatinued quite numerous up to the 29th. May 2-The bulk cleparted, and on the 11th, 14th, and 16th there were a few young; none seen later except on May 24, one in adult dress, but in diseased condition, which accounted for its presence here. Jefferson-Transient. On March 24 first saw two, and were not seen again until April 23, when the first of the regular migrants came. By April 28 they had increased slightly, and by May 2 there was quite an increase, and the,bulk of the species. In the evening I found more than a 
hundred, with a few white-crowns, in a patch of thick brush. May 4-About sume number, but more scattered, and in several new places. Way jHeight of the season; everywhere, in quite large flocks and small purties. Two hundred and fifty were seen in a five-mile walk; not very many white. crowns among them. May 6-Bulk departed. Only about one-tenth of yesterlay's birds remain. By the 'th many more had left. In the three places where they had been most common only one bird was folind, but a fluck of eighteen or twenty was seen in a new place. May 12-Two were seen, and on the 14 th the last one.

Tree Sparrow (S. Montrna). St. Louis.-Winter visitant. These hold second place in numerical strength of Winter birds. During January and February they rather increased, but during the week ending with February 21 they somewhat diminished, probably by the withdrawal of the reinforcement which came the first of the month. In sunny places they begin to be musical about this clate. On March 2 they were in very large flocks, especially in the lowlands on the Illinois side of the river; greatly outnumbering there the snowbirds, which are the more numerous on this side. March 11.-Have thinned out considerably. March 14.-Were found in several places, but not numerous. March 17.- Still with us, but few in numbers. April 7.-Last one seen. Jefferson.-A few are Winter visitants, but much the larger portion are transients. On March 24, first saw a flock of fifteen, which remained for nearly a month. On April 4 the bulk of the species were here, and on the 12 th was the height of the season; about one hundred and fifty seen. Only two days later (the 14th) but four birds were found in a long walk. April 21.-One flock of ten or twelve was found in a thicket; none at the brush piles, where I have found them all the Spring. These were the Iast I saw.

Chipping Sparrow ( $\$$. domestica). St. Louis.-Summer sojourner. First seen on April 4. Bulk of the species here on April 9, and by the 15th they lad commenced building. Jefferson.-Summer sojourner. On April 11 first saw six single males. April 12.-A few more came. Transients left about April 16, but another wave came on May3, which made them a gain numerous.

Clay-colored Sparrow (S, prllid $\iota)$. Seen neither at St. Louis for Jefferson.

Field Sparrow (S. pusillı). St. Louis-Summer sojourner. On MIarch 13 first saw one male, in song, at the same place at which I found the first bird last year, twelve days earlier, on March 1. March 16.-Several old acquaint. ances have returned, and are sitting on the same trees as in former years. They are full of praise, if song means praise. March 1\%.--A few more-the Wulk of the species. March 30.-The height of the migration. Jefferson.-Summer sojourner. First seen by me on April 2.5, but they probably came some time before. May 10. - Seen for the second time; seems to be quite uncommon about here.

Black snowbird ( $J$. hyemrlis). St. Louis-Winter visitant. Met with everywhere; it is the most numerous of our Winter birds. They increased durin . Tanuary and the first part of February, and then in the latter part of the same month the new arrirals seemed to leave us again. March 11-Are decidedly less numerous, and what is more important, they are much less conspicuous than during the last month. They keep silent, and on the ground, even during the warm hours, and on disturbing them I was surprised at the large proportion of light-colored individuais among them. Iudging from this and 
from their different behavior, I think that many of the old birds, which were in fine plumage in February, have departed, leaving behind the young birds, which will remain with us three or four weeks longer. On March 14 they were found in several places, but not numerous. March 16-As numerous as ever, and in large flocks; many old birds among them. Again on the 17th large flocks were seen. On March 30 they were found collected in large flocks, and very much excited in spite of the cool rain, and in a place where twenty wintered, I found an army of two hundred, singing, chasing, etc. On April 4 the bulk of the species departed, and the last one was seen on April 12. Jefferson-Winter and transient visitor. The first single ones came from the north October 17, 1882, and the first flock-over a hundred -on October 20. By November 8 they had scattered into small parties of five to eight, and these nearly all left in December. Parties of from three to seven were seen on January 3, 8 and 31, and then only one bird until March 23, when one flock of from eighteen to twenty appeared. Small flocks were seen until April 2, they then suddenly increased, and the bulk came on April 4. I then saw about one hundred and fifty in a few acres. The same day (April 4) was about the height of the season, for large numbers, perhaps the bulk, left that night. On April 12 only three were seen, and I thought each day would take away the last one, but they stayed-though quiet and looking very disconsolate-until on April 28, when the last straggler departed.

Song Sparrow $(\boldsymbol{H}$. fasciata). St. Louis-Winter visitant. Not many, but certain to find a few along the banks of creeks. Same conditions and numbers continued all through December, January, and February. On March 9 they were found in a very musical mood, but in same numbers. March 13New arrivals observed, and on the 14th song was heard in many places. April 6-The height of the season. The bulk departed on April 8, and the last one,was seen on April 9. Jefferson-Summer sojourner. First saw three on March 24, and during the week from March 25 to 31, seven were seen. April 4-Everywhere in twos and threes; forty to fifty seen. On April 12 was the height of the season; two hundred seen. April 14-Not one-tenth were left, but by the 21st they were more numerous, and in about Summer numbers.

Swamp Sparrow ( $\boldsymbol{M}$. palustris). St. Louis-Winter and transient visitor. On January 29 one bird was found in the same place as last Winter. March 2 and 8.-Three birds were seen, and on the 14th they were seen several times. The bulk arrived on April 4, and the height of the season was on the 9th. April 17.-Decreased; one party only, but on the 20th there were small parties in many places, and they were still numerous on May 2. May 5.-Last. May 14, 15 and 17.-Single young birds. Jefferson.-Summer sojourner. I saw the first one on April 28, but they probably came a week or more ago.

Lincoln's Finch (M. lincolni). St. Louis.-First seen on April 23. May 1. -They are strangely missing, but on the 14 th and 16 th I saw four birds. Jef1erson.-Not seen.

Fox Sparrow ( $P$. itiaca). St. Louis.-Transient. First saw two on February 20, and on March 11 a few additional individuals. March 14.-Found three at one place and several at another, all singing. On April 3 was the height of the season. April 5.-The bulk departed, and the last one was seen on April 7. Jefferson.-Transient. First saw twenty-four in two places 
on April 4, at which time possibly the bulk of the species was here. Last seen on April 11.

Chewink ( $P$. erythrophthalmus). St. Louis.-Summer resident and sojourner. Three birds seen on December 30 , and they stayed through January and February, both male and female. On March 14th calls were heard in three places, and on March 16 saw only four males. The bulk of the species were here on April 5, and the height of the season was from April 9 to 15, and longer. On April 15 they commenced building. Jefferson.-Summer sojourner. First saw three males on April 21, and on the 25th were heard several males. May 3.-Not more than twenty seen so far this Spring, and no females. On May $10 \mathrm{a}$ few females arrived, and by the 12 th it was almost at the height of the season. May 17.-Bulk of the females arrived, and the height of the species. On May 19 the height was past and are building.

Cardinal Grosbeak (C. virginiunus). St. Louis--Summer resident. Was seen every day, single or in pairs. Jefferson.-Does not occur.

Rose-breasted Grosbeak (Z. ludoviciana). St. Louis.--Summer sojourner. On April 22 first saw two males in song at old stands. The bulk of the species was here from April 25 to 29, on the last of which clates they were the most conspicuous and noisy birls. The females have arrived, and old males are back in full numbers. Jefferson.-Summer sojourner. On May 6 first saw four; all males. May 7.-About one-tenth are here, and on May 8 they were somerhat more numerous. May 10.-Females arrived, but only a few. May 12. - About the height of the season for males, and on the 1\%th was the height for females. May 19.-About in full numbers, and inost of them mated.

Indigo Bunting (P. cyanea). St. Louis-Summer sojourner. First saw a finck of about eight males on April 21. This species and the next were together and in company with white-crowns feeding on ploughed ground, alongside a hedge, which borders a pond. May 1.-Are scarce, but have met with singing males once or twice each day. May 2.-Bulk of the species. First females and many males in song. May 3.-Wandering troops. JeffersonSummer sojourner. First saw one male on May 17, and again on the 19th several wiere seen, but no females. May 29.-First fetmale.

Black-throated Bunting (S. amerierena). St. Louis-Summer sojourner. On April $\% 1$ first saw a party of twenty singing males. April 29.-In small flocks, which dispersed during the morning hours of warm days; re-entering old stancis. May 1.-The bulk of the species and they are now very conspicuous in the mornings, singing or flying singly, or in parties calling. Jefferson.Occurs only as a rare straggler, but not seen.

Bobolink (D. oryzivorus). St. Louis.--Transient. On May 2, in the evening, great numbers were seen going north in five large flocks. May 3.-Two males mere seen in company with redwings, and by the 5th they were present in large numbers, and from the 15th to the 1\%th I noted a flock of a hundred and fifty males and females. Last one was seen on May 21. Jefferson.-Summer sojourner. First saw one flying and singing on May 5 and on the 6th two more. Iay \%.-There was a slight increase; about a dozen seen, and on the 10th there was a still greater increase, but they were not yet common. The bulk arrired on May 12, and on the 19th. was the height for males, though not for females. On May 26 the first females came and on June 1 they were thinking about building. 
Cowbird (M. ater). St. Louis.-Summer sojourner. First seen on April 5 , and the height of the season was on the 12th. Jefferson.-Summer sojourner. On April 21 first saw one flock of about forty males and females. The bulk of the species arrived on April 28, and on May 12 it was the height of the season: about five hundred seen. May 19.-Just about in Summer numbers.

Yellow-headed Black-bird (X. icterocephalus). st. Louis.-Rare visitor; not seen this year. Jefferson.-Not șeen, but may occur locally, as I know it is a regular breeder at Green Lake, fifty miles north of here. At that lake, twelve years ago, I found only one pair, breeding at the south end the next year three pairs, and two years later they were quite numerous there, but nowhere else. The next year one pair moved to the north end of the lake, and this Summer on revisiting the place, I found them all around that lake and several neighboring ones.

Red and Buff-shouldered Blackbird (A.phceniceus). St Louis.-Summer sojourner. On March 3 first saw many small flocks in the swamp on the Illinois sicle of the river just opposite St. Louis, but none here yet. By March 11 they had spread a little more in small troops, mostly males, and on the 14th they were the most conspicuous birds in the lowlands. Vast numbers were in noisy flocks; mostly males. On Narch 17 large flocks went north above the river, and on April 4 the number here was very great. April 6.--Height of the season, which continued up to the 29 th. Jefferson.---Summer sojourner. First saw nine on March 17 and on the 23d the first flock, which was the last until April 4, when, in the evening, two bundred and fifty went north. On April 9 rery few seemed to have passed and a walk of half a dozen miles did not reveal as many flocks. On the 12 th they were for the first time common, but there were no large flocks, but a good many scattering single ones, all males and all singing. April 21.---First females. April 28.-..-Height of the season.

Meadow Lark (S. magna). St. Louis-Summer sojourner. First seen on March 3, when they were quite numerous and noisy in Illinois, opposite the city, but only once met with on this side of the river. By March .11 they were slowly taking up old stands, and on the 14th their song was heard on all sides, unusually numerous this year. Jefferson-Summer sojourner. On March 23, first saw fifteen totwenty single males; no females until April 1, and no flocks at any time. All that were here on April 9 were mated.

Orchard Oriole (I. spurius). St. Louis-Summer sojourner. On April 18 first saw one male, which was very dark, and on the 19th another one, singing. April 21.-First male of last year, and on the 22nd there was a slight increase. April 29.-It is becoming quite prominent; the first female and a few males of last year have arrived, but the species is not yet at its height. May 3.Bulk of the species, and in wandering troops. Jefferson-Should be here, but not seen.

Baltimore Oriole (I. gulbula). St. Louis-Summer sojourner. On April 19, first saw two, which were shy, and almost silent. April 20.-Two more, and on the 22nd a slight increase. April 29.-Bulk of the species, and they are to-day the most conspicuous and noisy bircls. The females have arrived, and old males are back in full numbers. Jefferson-Summer sojourner. First seen on May 6 , and the next day about one-tenth were here. May 8.-Somewhat more common. On the 10 th the females arrived, but only a few, and 
the 12th was the height of the season for males, but not yet the bulk of the females. May 19.-The height of the season is past, but yet no signs of building.

Rusty Blackbird (S. ferrugineus). St. Louis-Transient. On December 28 first saw about thirty resting on a high tree. Not usually found here in Winter. On March 14 there was quite a number in small flocks in the lowlands. Last seen on April 13. Jefferson-Probably seen, but not certainly: identified.

Purple Grackle (Q. purpureus ceneus). St. Louis-Summer sojourner. Saw four on January 18 and two more on the 29th. On March 14 the first of Summer sojourners came; a very few among the other blackbircls in the low. lands. March 16-First seen in Missouri. On April 15 they were mating but still going to the common roosting place. April 22-At this clate they were carrying building material. Jefferson-Summer sojourner. First saw one on March 25. March 31-Seen seven times this Spring, ten bircls in all. In the afternoon of April 4 I saw the first flock, numbering eleven, and later another flock migrating. On April 9 they began building in my yard. April 21- Two small flocks were seen, but not yet mated.

Common Crow (C.frugivorus). St. Louis-Resident. Roosting by thousanuls in Winter among the willows opposite St. Louis. On March 14 only a few were seen in the lowlands, where they had been very numerous two weeks before. Jefferson-Winter sojourner. About half a dozen wintered with us and were seen every few days. A few more pissed through in early Spring, but no larger flock than a dozen was seen at any time. Two full sets were found on April \%.

Blue Jay (C. cristata). St. Louis-Resident. Generally found in troops of from five to seven. On April 27 twenty were seen in a flock on wing and again on May 1. Jefferson-Resident

Shore Lark (E. alpestris). St. Louis-Resident. On February 24 they were the most conspicuous of our birds; mating and singing. They are often seen now in the air, singly, with a hovering flight, as if uncertain what direction to take, and making an inquiring call as if in search of somebody. They rise to a height of several hundred feet, drift slowly along for a mile or so and then after a few minutes return to the very spot they had left. JeffersonUsually Summer sojourner and sometimes a Winter sojourner in small num. bers. The first for 1883 came on February 24. By April 4 all migrants had left.

Kingbird (T. Carolinensis). St. Louis.-Summer sojourner. First saw a silent one on April 18-a beautiful bird-and on April 20 a second one was seen. April 29.-Begins to be conspicuous, and by May 1. it was increasing slowly. Jefferson-Summer sojourner. On May 6 first saw only one, and on the 7th three more, but silent. May 10.-Bulk of the species and almost the height of the season-a great increase. May 12.-Height of the season By the 19th the height had passed.

Great-crested Fly-catcher (II. crinitus). St. Louis.-Summer sojourner First saw two on April 17; they were silent. On April 20 the bulk of the species came; noisy Jefferson...-Summer sojourner. First saw one on May 12, and on the 19 th one more. Only about a dozen seen during the whole Summer.

Phoebe Bird (S. Fuscus). St. Louis.-Summer sojourner. First saw a pair 
on March 16, and on the 17th two more. A nest was found on April 9. Jefferson---Summer sojourner. On April 4 first saw three, and on the 9th about three or four to the mile. April 10.--Quite common; on the 11th there was no increase, but a few more on the 12th.

Olive-sided Flycatcher ( $C$. borealis). St. Louis.--'Transient. First seen on May 22, and last on the 24th. Jefferson---Not seen.

Wood Pewee ( $C$. virens). St. Louis.--Summer sojourner. On May 5 first saw several; calling. Jefferson.--Summer sojourner. On May 26 was the first I saw, though I think it came long ago.

Yellow-bellied Flycatcher ( $E$. flrviventris). St. Louis.-Transient. On May 14 first saw one bird and again on May 16. Seen also on May 21 and 24. Last on May 26. Jefferson.-Transient. First saw one male on May 19.-Last one on May 28.

Acadian Flycatcher (E. Acadicus). St. Louis.--Summer sojourner. On May 3 many more were seen at old stands. Jefferson.--Not seen.

Traill's Flycatcher (E. pusillus trailli). St. Louis.--Summer sojourner. First saw several, and heard them calling on May 5. Jefferson...-Not seen.

Least Flycatcher ( $E$. minimus). St. Louis.--Transient. On May 5 first saw one male, which was calling. From May. 14 to 18 they were numerous. Jefferson....Summer sojourner. First sav one on May \%, and on the 8th it was seen sereral times. May 10.--Nearly full numbers, and on the 12th was the height. They are present everywhere and have seemed to increase regularly from the first. May 19.-.-Still the height; over a hundred scen. June 1.--Still decidedly numerous.

Ruby-throated IIumming bird (T. Colubris). St. Louis-Summer sojourner. First saw one male on May 11, and on the 1th the first female. May 18.Mating. Jefferson-Summer sojourner. First saw one male on May 15. May 19.-Three seen and two shot with No. 10 shot; not a feather injured. June 1 -Height of the season.

Chimney Swift ( $C$. prelusgicrt). St. Louis-Summer sojourner. First seen on April 8. By the 14 th they had increased, and on the 18th the bulk of the species was here. Jefferson.-Summer sojourner. On May 1 first saw six, which came in the afternoon, and tonk immediate possession of mychimney. May 4.-..First flocks have almost gone; only three or four birds are circling orer the city to-day. May 9.-Flock of seventeen seen, apparently migrants. In the afternoon there were many more and the height of the season. May 12.-Migrants have about all gone.

Whip-poor-will (C. inciferus). St. Louis-Summer sojourner. First seen on May 2?, but prolualy came before. Jefferson-Summer sojourner. On May 19 first saw one pair, and none heard or seen thereafter.

Niglt Hawk (C. pmptue). St. Louis-Summer sojourner. First seen on May 15, and alsn on the 16 th and 18th, when there were a great many going north; numerous along the border of wood. Jefferson-Summer sojourner. First saw one on May 21, and on the 31st I found fresh eggs.

Hairy Woodpecker ( $P$. villosus). Resident at both places.

Downy Woodpecker (P. pubescens). Resident at both places.

Tellow-bellied Toodpecker (S. varius). St. Louis-Transient usually. On December 28 saw one in the woods, but no more seen during the remainder of the Winter. The first this Spring were four hirds, with no adult male 
among them, seen on February 22. March 11.-Still the same at this clate, and on March 13 a newly-arrived female was seen, and on April 4 and 5, an old bird in high plumage. Jefferson.--Summer sojourner. On April 4 first saw one flock of fifteen to twenty males and females; very active, mating, and a few in pairs. April 12.-The flock seems to have passed on, as I found only one left. No more flocks seen during the Spring, but single ones and pairs seen every few days.

Pileated Woodpecker (II. pilertus). St. Louis.-.-Resident. Seen on May 22. Jefferson.-.Not seen.

Red-bellied Woodpecker ( $C$. carolinus). St. Louis.--Summer, and I think also Winter, sojourner. On February 22 first saw two pairs, which were very much excited and noisy at breeding stands. Jefferson.-.-Probably seen, but not certainly identified.

Red-headed Woodpecker ( $\boldsymbol{M}$, erythrocephalus). St. Louis.-Summer resident. Remained through the Winter; two single birds and ne pair seen in a week. On February 22 they were in the same numbers. On April 12 many were found in heavy timber, but not generally distributed. May 1.-Evident increase during the last few days. Jefferson....Summer sojourner. On May 6 five males came in the afternoon, and during the following night about fifteen per cent came. May 12...-Almost the height of the season.

Yellow-shafted Flicker $(C$. aurutus). St. Louis.-.-Summer resident. Remained through the Winter; two sern in one week. On March 14 several were here in company with robins and blackbirds. The bulk of the species Was here on April 4, and from the 4th to the 8th was the height of transients. Jefferson.---Summer sojourner. First saw one on A pril 8, and next day three more. On April 9 there were a few more, and on the 10th they were heard erery few minutes. On April 11 there was no increase, but the 21st brought us a flock of seven.

Belted Kingfisher ( $C$. alcyon). St. Louis.--Summer sojourner. First seen on April 6, and by the 14th they were nest digging. Jefferson.-.-Summer sojourner. First saw one on April 4, and on the 11th two birds, seen for the third time.

Yellow-billed Cuckoo (C. rmericrnus). St. Louis.--Summer sojourner. First one noticed on May 16. Jefferson.--Summer sojourner. This and the next were undoubtedly seen about May 21, but not close enough to distinguish them.

Black-billed Cuckoo (C. erythrophthalmus). St. Louis.-.-Summer sojourner. First seen on May 2. 





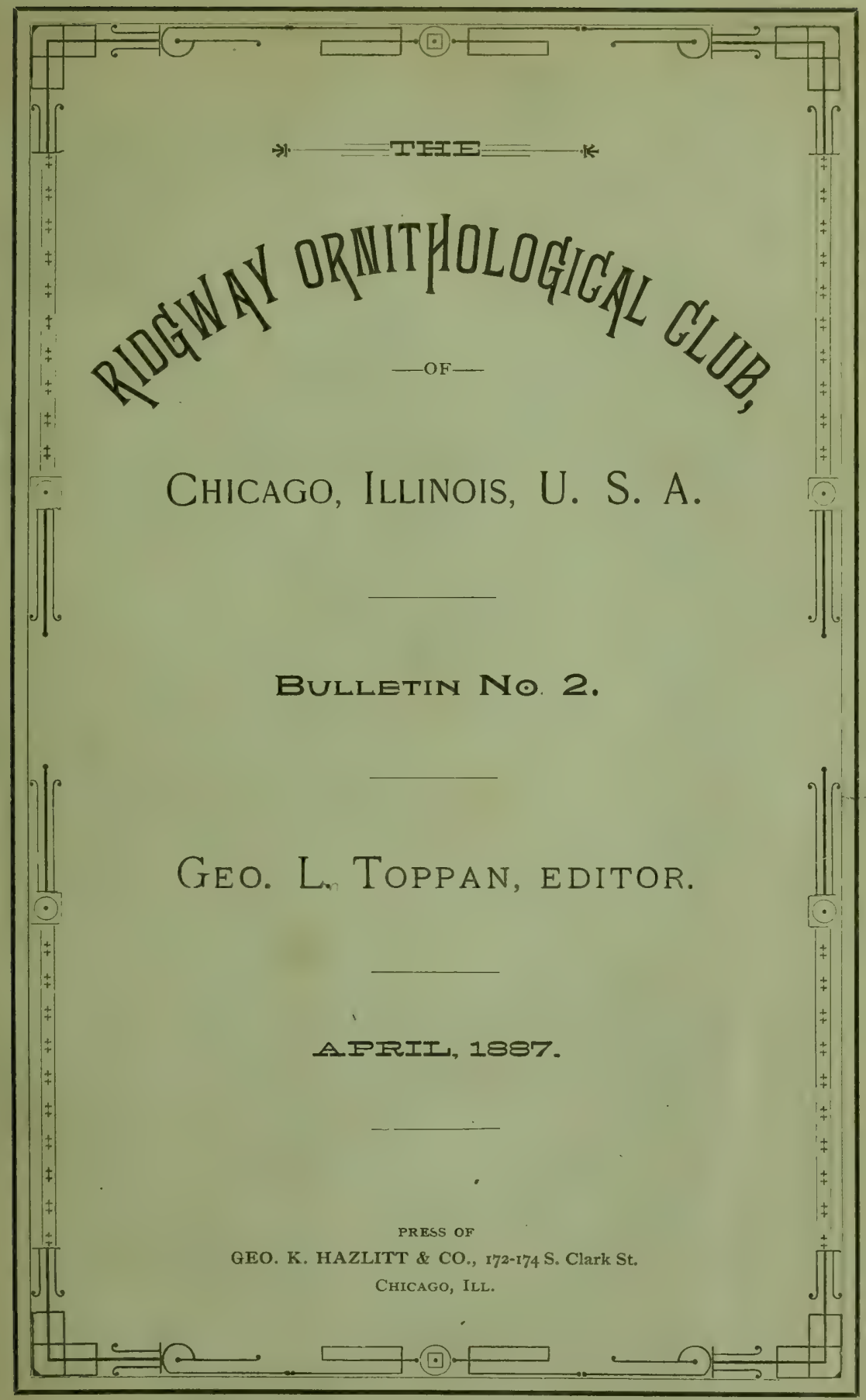





$$
\rightarrow-\text { THE_.... }
$$

Ridghay OpNithologigal Glub,

CHICAGO, ÍllinOIS, U. S. A.

Bulletin N॰. 2.

GEO L. TOPPAN, EDITOR.

$$
1887 .
$$





\section{EDITORIAL.}

Our first publication was so well received and we are in receipt of so many encouraging words in reference to it, that it has been decided to publish, at such intervals as may seem expedient, a series of bulletins. These will be composed mainly of papers read before the Club, and will be confined mostly, if not entirely, to the ornithology and cölogy of North America, north of the Mexican boundary-line.

Several papers appear in the present number which were written prior to the publication of the new Code and Check-list of The American Ornithologists' Union, and, as the classification and nomenclature therein given have been adopted by the Club and ornithologists generally, we have taken the liberty of revising such papers so that they may conform to this list.

In this connection a short history of the Club may be interesting.

Sometime during July, I883, a notice was sent to several persons in the city that an attempt would be made to organize an Ornithological Club. On August 23d the following named gentlemen responded in person:
Dr. J. W. VELIE,
G. Frean Morcom,
F. L. RICE,
C. C. Whitacre, Jos. L. Hancock,
A. J. White,

$$
\text { Geo. L. Toppan, H. K. Coale, }
$$

All agreed that it.would be a good thing to have a club in the city, and a committee was appointed to draft a constitution and bylaws. These were adopted at the next meeting, (Sept. 6th), when the Club was duly organized with ten active members.

It was moved and unanimously carried to name the Club The Ridgway Ornithological Club of Chicago, in honor of the eminent ornithologist, Mr. Robert Ridgway, of Washington, D. C.

Officers for the first year were elected as follows:

Dr. J. W. Velie, President; G. Frean Morcom, Vice-President and Treasurer; H. K. Coale, Secretary; Jos. L. Hancock, Curator; F. L. Rice, Librarian.

At the meeting held March 6th, 1884, the question of incorporating the Club was discussed and a committee appointed to 
investigate it. This was done, and, as the report was favorable, it was brought before the Club at the April meeting. An affirmative decision was arrived at, and on April 2Ist, I884, the Club became an incorporated body under the laws of the State of Illinois. So far we have lost but two of the original members, while many others have since joined us.

The Club owes much of its success and prosperity to its efficient Secretary and Treasurer, Mr. H. K. Coale, through whose efforts its organization was first secured and whose unflagging interest in its success has done much to promote its general welfare.

During the past year our constitution and by-laws were found to be very incomplete, and at a special meeting held February I6th, 1886 , the subject was discussed, and a committee of three, consisting of Messrs. Toppan, Deane and Coale, was appointed by the Chair to make the necessary revisions. The report of this committee was received at the next regular meeting, March IIth, and at the April meeting it was accepted and the new constitution and bylaws went into effect.

In the last fiscal year the following donations were received and are hereby gratefully acknowledged:

From C. B. Cory, a copy of three of his works. (A Naturalist in the Magdalen Islands, Birds of the Bahamas, and Birds of Hayti and San Domingo.)

From R. Ridgway, six books. (5 vols. Baird, Brewer \& Ridgway, N. A. Birds, a copy of the A.O.U. Code and Check-list, and a number of photographs illustrating the sylva of the Wabash Valley of Illinois.)

From A. W. Butler, a copy of the Bulletin of the Brookville Society of Natural History.

From E. W. Nelson, a copy of his Alaskan Notes.

From C. W. Beckham, a copy of his Birds of Kentucky.

From H. Seebohm, three vols. of his British Birds' Eggs.

From J. M. Wheaton, one copy of his Report on the Birds of Ohio.

From H. Coale, a number of skins of foreign and native birds and several nests and eggs of native birds.

The Editor. 


\section{CONSTITUTION AND BY-LAWS}

OF

THE RIDGWAY ORNITHOLOGICAL CLUB OF CHICAGO.

\section{CONSTITUTION.}

\section{ARTICLE I.}

NAME.

This Club shall be known as the Ridgway Ornithological Club of Chicago.

\section{ARTICLE II.}

OBJECTS.

The object of this Club shall be the increase and diffusion of ornithological knowledge, by the reading and publication of original papers; the interchange of personal experiences; the acquisition of a Library and Collection; and other suitable means.

\section{ARTICLE III.}

OFFICERS AND COMMITTEES.

Sec. I. The officers of this Club shall be a President, VicePresident, Secretary and Treasurer, and a Curator and Librarian.

Sec. 2. The Standing Committees shall be as follows: a Committee on Membership, consisting of three; a Committee on Finances, consisting of three.

Sec.3. All officers and members of Standing Committees shall be chosen by ballot at the annual meeting, and shall serve until their successors are duly elected. 
Sec. 4. Members of Committees shall serve three years, their terms of office expiring in such a manner as will render the election of one new member necessary at each annual meeting.

Sec.5. Vacancies occurring from any cause in any of the regular offices of the Club or Standing Committees, shall be filled by ballot at any regular meeting, notice of such election being given by the Secretary:

\section{ARTICLE IV.}

\section{DUTIES OF OFFICERS AND COMMITTEES.}

Sec. I. The duties of the President shall be those usually pertaining to his office.

Sec. 2. The same shall be the duties of the Vice-President in the absence of the President.

Sec. 3. The duties of the Secretary shall be those usually pertaining to his office.

Sec. 4. The Treasurer shall receive all initiation fees and dues, and pay all approved bills. He shall keep an accurate account of receipts and expenditures, and the financial relation of members to the Club, and present a statement of the same at each annual meeting.

Sec. 5. The Curator shall have charge of the Collection. He shall see that all specimens are correctly labelled and recorded in the register of the Collection, and shall make a report of the condition of the Collection at each annual meeting.

Sec. 6. The Librarian shall have charge of the Library. $\mathrm{He}$ shall see that all books, pamphlets, reports, or publications of any kind received by the Club are duly numbered and catalogued, and shall make a report of the condition of the Library at each annual meeting.

Sec. 7. It shall be the duty of the Committee on Membership to examine into and report on the standing of each applicant for membership at the meeting following that on which such application was made.

Sec. 8. It shall be the duty of the Committee on Finances to incur all necessary expenditures and approve all bills before they shall be paid by the Treasurer; they shall also examine and audit the Treasurer's accounts, and make a report at each annual meeting.

Sec. 9. The President, Vice-President, and Secretary, shall be ex-officio the Executive Committee of the Club, whose duties it 
shall be to provide suitable scientific work for the meetings, and to determine the order in which papers and reports shall be read and considered.

\section{ARTICLE V.}

\section{MEMBERSHIP.}

Sec. 1 . The Club shall consist of Active Members, Corresponding Members, and Honorary Members.

Sec. 2. Any ornithologist of good standing shall be eligible for membership.

Sec.3. Each applicant for membership must be recommended in writing by at least two members of the Club. If the report of the Committee on Membership be favorable, the applicant shall then be balloted for, and if four-fifths of the votes cast be in his favor, he shall be declared elected. Such election must be consummated by the payment of the initiation fee within thirty days.

Sec. 4. Any member in good standing may withdraw from membership by paying his dues and notifying the Club in person or by letter.

Sec.5. Any member who shall be found guilty of ungentlemanly conduct or dishonest dealings, may be expelled or removed from office by a three-fourths vote of the members present at a regular meeting, provided that the charges shall have been investigated and sustained by a committee of three who shall be appointed for that purpose, and due notice has been sent to every member stating the date of meeting at which final action is to be taken.

Sec. 6. Candidates for admission into the Club as corresponding members must be proposed in writing by two members and balloted for, any candidate receiving three negative ballots being rejected. A candidate rejected for corresponding membership shall be ineligible thereto for two years after such rejection. Corresponding members shall be entitled to all the privileges of active membership, except the right to vote or to hold office.

Sec. 7. The Club may elect, by unanimous vote, distinguished ornithologists to honorary membership, who shall be entitled to all the privileges of active membership, except the right to vote or to hold office.

Sec. 8. Corresponding and honorary members shall be exempt from payment of dues. 


\section{ARTICLE VI.}

AMENDMENTS.

This Constitution may be amended at any regular meeting, by a vote of three-fourths of the members present, provided that notice of such proposed amendment shall have been given at the meeting preceding the last meeting of the Club, and have been mailed to every member.

\section{BY-LA WS.}

\section{ARTICLE I.}

\section{MEETINGS.}

This Club shall meet on the second Thursday evening of each month. The meetings occurring on the second Thursday in May shall be known as annual meetings, and others as regular meetings. Special meetings may be called at any time by the President, or on written request of three members. But at such meetings cognizance shall be had of such business only as is specified in the calls for the same.

\section{ARTICLE II.}

\section{QUORUMS AND ORDER OF BUSINESS.}

Sec. $I$. At annual meetings seven members shall constitute a quorum. The order of business shall be:

I. Reading of Minutes.

2. Annual Reports of Secretary, Treasurer and Standing Committees.

3. Election of Officers.

4. Miscellaneous Business.

5. Adjournment. 
Sec. 2. At regular meetings five members shall constitute a quorum. The order of business shall be:

I. Reading of Minutes.

2. Report of Committee on Membership.

3. Election of Members.

4. Proposition of Candidates.

5. Reading of Papers and Discussion.

6. Reception of Donations.

7. Correspondence.

8. Reports of Committees.

9. Unfinished Business.

I0. New Business.

II. Adjournment.

\section{ARTICLE III.}

DEBATE.

No member shall be entitled to more than ten minutes in discussing any subject or motion except by special invitation of the Club.

\section{ARTICLE IV.}

\section{FEES AND IUUES.}

The initiation fee shall be three dollars. The annual dues shall be six dollars, payable annually or semi-annually. No mem. ber who shall be in arrears for dues at the time of the annual meeting shall be entitled to vote, and if any member fail to pay his dues for one year he may be suspended, but he may be restored to membership by a vote of the Club and payment of all arrearages.

\section{ARTICLE V. \\ COLLECTION AND LIBRARY.}

No books shall be taken from the Library, or specimens from the Collection, except with the permission of the Curator and Librarian, and he shall in all cases take a receipt for the same. 


\section{ARTICLE VI.}

\section{AMENDMENTS.}

These By-Laws may be amended at any regular meeting by a vote of three-fourths of the members present, provided that notice of such proposed amendment shall have been given at the meeting preceding the last meeting of the Club, and have been mailed to every member.

\section{ARTICLE VII. \\ RULES OF ORDER.}

Robert's Rules of Order shall be the parliamentary guide in the meetings of this Club. 


\title{
NOTES AND OBSERVATIONS ON THE ORNITHOLOGY
}

\author{
OF
}

\begin{abstract}
CORPUS CHRISTI AND VICINITY, TEXAS.
\end{abstract}
BY JOSEPH L. HANCOCK.

The presentation of these notes on the birds of Corpus Christi and vicinity is the result of my observations from March 16 th to April Ist, 1884 .

The object of the trip South was to collect material and make notes of the birds on the Lower Rio Grande of Texas, but upon arriving at Galveston, I found that the steamer which formerly plied between Galveston and Brownsville did not stop at Corpus Christi, at which place I intended to remain a sufficient length of time to take notes of the wading birds. I proceeded to Corpus Christi by rail, where I felt it advantageous to remain, as I had the co-operation of an able assistant, and as the locality presented an unusual harvest for ornithological research.

Expression of my grateful acknowledgment to Mr. George F. Morcom, of Chicago, in whose interest the trip was taken, is given within, and were it not for a severe illness contracted on a camping tour, these notes would have been swelled to a volume.

I. Larus argentatus smithsonianus Coues. (American Herring Gull). Common on the coast and about the Bay.

2. Gelochelidon nilotica (Hasselq.). (Gull-billed Tern). Observed on the coast of the Bay March 26th. A set of three eggs was taken, together with the male bird, on Bird Island, May $23 \mathrm{~d}$.

3. Sterna tsciegrava Lepech. (Caspian Tern). Seen about the Bay March 26th.

4. Sterna forsteri Nutt. (Forster's Tern). Quite common about the Bay and on Bird Island March 26th.

5. Sterna fuliginosa Gmel. (Sooty Tern). Observed about the reefs March 26th.

6. Rynchors Nigra Linn. (Black Skimmer). A male and 
female were taken May 25th, together with a set of five eggs. No nest was built, the eggs being deposited on the bare ground.

7. Phalacrocorax mexicanus (Brandt). (Mexican Cor. morant). Several birds were seen on the tops of old piles that projected from the water some distance from the coast at Corpus Christi. This species is evidently the same as that observed by $\mathrm{Mr}$. Sennett.*

8. Pelecanus erythrorhynchos Gmel.

(American White Pelican). Several flocks were seen flying over the city in the latter part of March.

9. Pelecanus fuscus Linn. (Brown Pelican). On March 26th I saw large flocks of these birds across the Bay from Corpus Christi, and on April I $5^{\text {th }}$ a friend took five eggs on Bird Island. The eggs were laid on the bare ground.

Io. Anas boschas Linn. (Mallard). Several specimens were shot on the Nueces River in company with the Gadwall.

II. Anas strepera Linn. (Gadwall). Seen in large numbers April 1st, on the Nueces River.

i2. Spatula clypeata (Linn.). (Shoveller). Several specimens were shot April 1st, on the Nueces River.

I3. Aythya americana (Eyt.). (Redhead). A few were seen April 1st, on the Nueces River.

I4. Aythy A AfFinis (Eyt.). (Lesser Scaup Duck). Large flocks were seen on the Nueces River April ist.

15. Chen hyperborea nivalis (Forst.). (Greater Snow Goose). On March $27^{\text {th }}$, as we drove up to Mr. King's ranch, which is located about ten miles rorth of Corpus Christi, a large flock of Snow Geese alighted in an adjoining pasture not twenty yards off. So tame were they, that, should one not well informed observe them, he would easily mistake them for the domestic goose. On our alighting from the wagon they rose from the ground, but settled down again a few paces off. My friend unhitched one of the horses and started after them, taking care to keep in step with the horse's front legs. When within a gun range, a large, dark, peculiarly marked specimen was shot.

Many could have been taken had we been so disposed.

i6. Ardea herodias, Linn. (Great Blue Heron). This beautiful bird was seen on the flats north of Corpus Christi on March ISth, and on May $15^{\text {th }}$ a nest containing three eggs was brought to me.

* Bull. U. S. Geol. Survey, Vol. V, p. 155. 
17. Ardea tricolor RUficollis (Gosse). (Louisiana Heron). Common on the flats north of Corpus Christi. A nest and five eggs were taken by my assistant in 1883 .

i8. Nycticorax nycticorax nevius (Bodd.). (Blackcrowned Night Heron). Observed specimens on the flats north of the city March $27^{\text {th. }}$ Five eggs were obtained, which were taken by a friend in June, $188_{3}$.

i9. Grus mexicaya (Müll.). (Sandhill Crane). March 29th, while on our homeward journey from a three days camping trip, several of these birds were seen about five miles north of the city, in an open field where the grass was knee-high. Several shots were fired at them from the wagon, but none were obtained. They were all in dark plumage.

20. Himantopus mexicanus (Müll.). (Black-necked Stilt).

A few were seen on the flats north of the city on various trips.

21. Macrorhamphus griseus (Gmel.). (Dowitcher). Two specimens were taken March 26 th on the coast northwest of the city. These were taken from a flock in which were a number of Sanderlings (Calidris arcnaria).

22. Calidris arenaria (Linn.). (Sanderling). Small groups of these birds were seen scattered along the beach feeding at the water's edge.

23. Symphemia semipalmata (Gmel.). (Willet). Common on the borders of Corpus Christi Bay and the flats.

24. Charadrius dominicus Müll. (American Golden Plover). Several flocks were seen on the flats north of Corpus Christi on March 26th.

25. Egialitis vocifera (Linn.). (Killdeer). A specimen was taken April ist about ten miles west of the city. Several were also seen on the edge of the Nueces River.

26. Arenaria interpres (Linn.). (Turnstone). Common along the coast at Corpus Christi and at Bird Island.

27. Hematopus palliatus Temm. (American Oystercatcher). While crossing the Bay, which lies about three miles west of the city, on the afternoon of March 26th. these birds were seen in abundance on the oyster beds, which at that time were almost entirely submerged. Here, together with Long-billed Curlews, $A$ vocets and other species of wading birds, they were seen in countless numbers.

23. Colinus virginianus texanus (Lawr.). Texan Bobwhite). A common summer resident. In fact the most common 
bird met with on my trips, and found in widely different localities. They are most common in open fields. In the middle of the day they generaliy seek some cover, such as is found sparsely dotting the fields. In the early morning they were most abundant, and the familiar note of "bob-white" was heard from all sides.

29. Meleagris gallopavo Linn. (Wild Turkey). Found in abundance in suitable places. On the evening of March 26th several were put to flight from some tall oak trees fifteen miles north of Corpus Christi, where they had settled down for their night's rest. The next morning while riding over the prairies our dog flushed many from the tall grass.

After being frightened from their roosts at night, they make for the open prairies; here they remain but a short time, as the wild animals, especially of the cat tribe, are a troublesome foe, continually on the alert to capture them.

From the many enemies of this bird, and the exposed situation of the nests, which are built on the open prairies, but a small average ever attain the mature state. Facts collected from an old hunter seem to point to a gradual extermination of the species.

3o. Zenaidura macroura (Linn.). (Mourning Dove). On March 27 th a nest of this bird with two eggs was taken about fifteen miles northwest of Corpus Christi. The nest was mostly composed of twigs of the mesquite, and was placed about eight feet from the ground. The female flew off at our approach, and gave expression to her uncomfortable position by a series of coos. That evening we pitched our camp by the side of a river about twenty miles from Corpus Christi. We were partly enclosed by large oak and ebony trees. Just after supper the whistling of the wings of the doves couid be heard as they flew over our heads to alight on the side of the stream for a drink. In succession they came, some in pairs, while again single ones would come one after another, only to stop long enough for a drink, when they would disappear as mysteriously as they came. This procession lasted until very late into the night, when, by degrees, it ceased.

31. Cathartes aura (Linn.). (Turkey Vulture). Seen roaming over the country feeding on dead animals, etc.

32. Catharista atrata (Bartr.). (Black Vulture), Scattered about the prairies are the remains of animals that perish from disease, etc. These remains mark the spots where the Vultures have made their gluttonous appetites of great service. Scarcely has 
the body of an animal become cold when the Vulture, which only a short time previous was out of the range of human vision, makes his appearance. Circling about for some time, they finally alight on the ground, at first at some distance from the animal, as if to investigate and make sure that all is right, at last one, more courageous than the rest, stealthily makes his way to the head and tears out the eye. I did not see them strip the skin from the animal.

33. Elanoides forficatus (Linn.). (Swallow-tailed Kite). On March 26th a pair were seen flying north. These were the only ones seen.

34. Circus hudsonius (Linn.). (Marsh Hawk). Many were seen migrating northwards.

35. Accipiter velox (Wils.). (Sharp-shinned Hawk). Several were seen on the various trips taken. One was obtained April 7 th.

36. Aquila chrysä̈tos (Linn.). (Golden Eagle). Just across the reef north of Corpus Christi a nest of this bird was seen.

It was conspicuously placed in the top of a large oak and was composed of large twigs loosely thrown together.

37. Polyborus cheriway (Jacq.). (Audubon's Caracara). A set of the eggs of this bird was brought to me on April 15th. Specimens of the bird were not taken, although seen quite often.

38. Megascops asio MCCAllii (Cass.). (Texan Screech Owl). Four miles west of Corpus Christi, March 26th, a female was taken off her nest, which contained two eggs of a dull white color. A peculiar accident happened to the eggs, which is, I think, worthy of note. In some way one of the eggs got cracked in the nest, thus letting out some of its contents. This albuminous substance caused the other egg, which lay by the side of the broken one, to adhere to the parent bird's breast. Upon the removal of the bird from the nest, the egg hung on sufficiently long to reach the outside, when it dropped off and fell to the ground. The nest was built in a dead ebony tree about five feet from the ground. The male was also captured alive, and the pair made very interesting pets about my friend's house.

39. Bubo virginianus (Gmel.). (Great Horned Owl). Common in the timbered country north of Corpus Christi. A fine pair was obtained March 29th; these were undoubtedly migrants. They are much lighter in color than northern specimens, which seems to be characteristic among the avian fauna in general in the South, es. pecially of land birds of a tawny color. 


\section{Geococcyx californianus (Less.). (Road-runner).} On the first trips taken west of the city I did not observe a single specimen of this bird; later, however, and at more distant points among the chaparral, we came upon one or more leisurely strutting about on the ground at every turn.

As soon as our appearance was known they made off, dodging in among the chaparral where it was almost impossible to trace them owing to the impenetrable nature of the bushes. On the morning of the 26 th of March, while pushing our way through the thick undergrowth, we came upon a bird in a cleared spot which was busily engaged in thrashing its bill against a large bone which laid partly buried in the ground. The cracking of the limbs as we pushed our way forward attracted its attention, and it sought safer quarters. An examination of the spot was made, and strewn about the ground near the bone were innumerable fragments of shells, the remains of the land snails which were caught near by and brought here to be broken open so that their contents might be devoured.

Among the chaparral ranging from three to six feet from the ground were last year's nests, some of which were partly rebuilt. But one revealed eggs, this was situated about four feet from the ground in the centre of a chaparral bush. The bird remained upon the nest until we were within a few feet, when it slyly crept out on the opposite side, lingering for a few minutes on the ground near by. The nest contained seven eggs of an opaque white color. Contrary to the generality of sets each egg was perfectly fresh. Well developed embryos in the same nest with fresh eggs are more often found.

41. Coccyzus americanus (Linn.). (Yellow-billed Cuckoo). A female with the nest and five eggs was taken April $23 \mathrm{~d}$.

42. Cerrle cabanisi (Tschudi). (Texan Kingfisher). A specimen was observed on a telegraph wire across the reef from Corpus Chrtsti, March 26th. A shot from my gun knocked it from its footing, which it was unable to regain. It then flew to the distant timber, where it was lost to view.

43. Dryobates scalaris (Wagl.). (Texan Woodpecker). Several birds were seen April 2d.

44. Melanerpes aurifrons (Wagl.). (Golden-fronted Woodpecker). On March $26 \mathrm{th}$, a male and female were shot from a telegraph pole fifteen miles north of Corpus Christi. The pair were evidently building a nest, as one had material in its mouth 
which it carried to a hole on the south side of the pole about fifteen feet from the ground. This was one of the many pairs seen.

45. Antrostomus vociferus (Wils.). (Whip-poor-will). Several were seen in some dense woods about fifteen miles north of Corpus Christi, March 28th. A specimen was also taken April 7 th, three miles west of the city.

46. Nyctidromus albicollis (Gmel.). (Parauque). Two specimens brought me by a friend were shot in the Nueces River bottoms April i6th.

47. Trochilus colubris Linn. (Ruby-throated Hummingbird). This familiar little bird was noticed quite often sipping the nectar from the honey-suckles, which are cultivated by some as a garden plant. It was also observed several miles west of the city among low bushes and among the blossoms of the China trees in the city.

48. Milvulus forficatus (Gmel.). (Scissor-tailed Flycatcher). On the morning of March $\mathrm{I} 8 \mathrm{th}$, while conversing with a friend on one of the principal streets in the central part of the city, one of these birds flew over slightly higher than the city hall near by. The novel aspect the bird presented as it towered aloft; the streaming tail, looking like a string tied to its body, was a sight never to be forgotten. This was the first arrival. After this date they became more common and were seen as commonly as the Pewee of the East. A series of chattering notes were the only traces of music observed. These were uttered continually by both sexes while on the wing.

The top branches of bushes and trees are their favorite resort; here they collect in little flocks, sometimes as many as eight or nine being seen together. From these branches they dart forth after such insects as may be passing.

I have noticed them fly almost perpendicularly upwards for several yards. When they suddenly descend the peculiar forked tail and salmon-colored sides are conspicuously shown, the whole making a picture which few of the feathered tribe can surpass in point of elegance.

A nest with five eggs and the female bird was secured on May $27^{\text {th. }}$

49. Myiarchus crinitues (Linn.). (Crested Flycatcher). Two specimens were secured March 2 Ist, four miles west of the city, in some chaparral bushes.

50. Sayornis Saya (Bonap.). (Say's Phcebc). While driv- 
ing through some heavy chaparral on the afternoon of March 27 th, one of these birds was seen Hying in the air after insects, a snapping sound being made with its bill while thus engaged.

5I. Otocoris alpestris giraudi Hensh. (Texan Horned Lark). Found this species very common on the flats north of Corpus Christi. On May 27 th a nest with four eggs was taken.

52. Molothrus ater (Bodd.). (Corvbird). Common. Seen in flocks west of the city. Two other species were observed, but specimens for identification were not taken.

53. Agelaius pheniceus (Linn.). (Red-winged Blackbird). On March 2 Ist several large flocks were seen west of the city. So numerous were they at this place that a single shot would have furnished more specimens that could have been taken care of.

54. Sturnella magna (Linn.). (Meadorelark). This bird was found to be very abundant in fields.

55. Sturnella magna neglecta (Aud.). (Western Meadowlark). Had I known that this variety was found at Corpus Christi, especial attention would have been given to its habits. However, its identity was not known until after my arrival home.

A male of this western variety taken on the flats just outside of the city limits, was shot from a flock. No difference of habits was noticed between this and the eastern form, excepting its song which appeared much shorter and more feeble in its utterance.

56. Icterus spurius (Linn.). (Orchard Oriole). Common resident. The nests of this bird are much smaller here than in the more northern and eastern parts of its range.

57. Icterus bullocki (Swains.). (Bullock's Oriole). A summer resident in suitable localities. A nest with five eggs was taken April 7 th.

58. Quiscalus Macrourus Swains. (Great-tailed Grackle). Soon after my arrival, March 16 th, the Great-tailed Grackle was very common in the city, inhabiting the $\mathrm{C}$ hina trees in the gardens, where their nests were scattered about among the top branches. Its notes could be heard from my window at almost any hour, but particularly in the early morning when they assemble in large flocks. To say the least, the notes are most displeasing in tone. The male birds at this season of the year strut about with a great deal of pride; they delight in straightening back their heads, in which operation the crown almost touches the back. They also swing the head back and forth with a dazed expression which reminds me of a domestic fowl hunting for its roost in the dark 
While thus maneuvering they burst forth with their sharp, grating notes, which have a near resemblance to the noise made by a gate swinging on rusty hinges. In the delivery of their song the throat swells to three times its ordinary size and it is seemingly with great effort that they burst forth, commencing with a shriek which breaks up into chattering notes. The noise as the wings and tail beat the air would stand comparison with that made by the pigeon.

They use the same nest year after year, giving it each season what little repairing may be necessary. Two broods are commonly raised in a season.

59. Poocetes gramineus confinis Baird. (WesternVesper Sparrow). Quite common at Corpus Christi, where it is found in the open fields and among the prickly pear cactus.

6o. Ammodramus sandwichensis savanna (Wils.). ( $S a$ vanna Sparrow). Common at Corpus Christi. They are met with wherever suitable places of concealment abound. Most often found under prickly pear and in open chaparral, or where the two mingle.

6I. Ammodramus sandwichensis alaudinus (Bonap.). (Western Savanna Sparrow). Found residing in about the same localities as the preceding species, but with more tendency to places where the vegetation was more scattered.

62. Ammodramus savannarum perpalidids Ridgw. (Western Grasshopper Sparrow). In open fields or on the ground among stunted cacti this sparrow was seen quite often. On March I 8 th, I noticed one of these birds on the ground under a large cactus, its peculiar docility aroused my attention and I shot it. On skinning it I found a parasite which had bored completely through its small intestine. This may have accounted for its unusual stupidity.

63. Chondestes grammacus strigatus (Swains.). (Western Lark Sparrow). Several specimens were taken March 27 th about twenty miles north of Corpus Christi. All were in bright plumage.

64. Spizella pallida (Swains.). (Clay-colored Sparrow). A number of these sparrows were seen March 24 th two miles southwest of the city among a scattered growth of chaparral.

65. Spizella pusilla (Wils.). (Field Sparrow). This bird was generally seen in scattered growths of cacti and chaparral.

66. Melospiza lincolni (Aud.). (Lincoln's Sparrow). This bird was seen occasionally on every trip and was sometimes in company with the White-crowned Sparrow. 
67. Cardinalis cardinalis (Linn.). (Cardinal). About the twenty-fifth of March the bulk of the migrants seemed to have arrived.

While perched on the top branch of a bush the male gives out his notes, which seem in beautiful harmony with his beautiful plumage. A little way off is the female; though less conspicuous in attire, its sharp chirp of alarm attracts your attention.

Here and there among the chaparral the bright, vivid flash of the males could be seen.

68. Passerina cyanea (Linn.). (Indigo Bunting). A few were seen during my stay. A male in bright plumage was shot two miles west of the city on April $\eta$ th.

69. Piranga Rubra (Linn.). (Summer Tanager). On the morning of April $7^{\text {th a }}$ bright plumaged male was observed among the China trees in the yard surrounding the house. This was the only one seen, although I am told by a friend that it is a common resident in the river bottoms of Nueces County.

7o. Progne subis (Linn.). (Purple Martin). Besides that of the Great-tailed Grackle the Purple Martin's sallow whistle was about the only bird music I had to contend with during my long confinement. They are very common.

71. Tachycineta bicclor (Vieill.). (Tree Swallow). A common summer resident at Corpus Christi.

72. Clivicola riparia (Linn.). (Bank Swallow). Several flocks seen across the Bay from Corpus Christi.

73. Ampelis cedrorum (Vieill.). (Cedar Waxwing). On the morning of March $26 \mathrm{th}$, fifteen miles north of Corpus Christi, a Cedar bird was seen on the top branch of an oak tree a little distance from our camp. Its wheezing note was the first thing to attract my attention. On May 22nd, the same familiar note was heard from my room in the city, my brother kindly identifying the specimen from my description, as I was unable myself to go to the window.

74. Lanius Ludovicianus excubitorides (Swains.).( Whiterumped Shrike). This hird was met with frequently. I have not observed it either devouring or in pursuit of other birds.

75. Vireo olivaceus (Linn.). (Red-eyed Vireo). Met with occasionally in oak timber across the Bay from Corpus Christi.

76. Vireo belli Aud. (Bell's Vireo). A male and female of this species, together with a nest containing three eggs and one 
of the Cowbird, was brought to me by my assistant, on May 28th. It was found on the bank of the Nueces River in dense undergrowth, and was placed about four feet from the ground.

77. Mniotilta varia (Linn.). (Black and White Creeper). The first specimen of this bird, a male, was collected March 2 Ist, four miles west of the city. The black markings about the head and body are the most pronounced of any specimen seen.

78. Heiminthophila pinus (Linn.). (Blue-winged Warbler). A male secured April $7^{\text {th }}$ on the bank of the Nueces River was the only one seen.

79. Helminthophila celata (Say). (Orange-crowned Warbler). Several seen March $27^{\text {th }}$, several miles north of Corpus Christi in company with the Parula Warbler. The top branches of oak and ebony trees were their most frequent habitat.

8o. Сompsothlypis americana (Linn.). (Parula Warbler). While on the camping trip of March 27 th I saw many of these birds in the upper branches of high trees. Associated with them were Blue-gray Gnatcatchers and occasionally a Black-throated Green Warbler.

81. Dendroica coronata (Linn.). (Myrtle Warbler). On the morning of March 26th quite a number passed through the yard adjoining the house where I was stopping. No more seen.

82. DendRoICA DOMINICA (Linn.). (Yellow-throated Warbler). The first of these birds was noticed March I 7 th, in some low growth of mesquite and prickly pear on the side of an embankment in the city. At first sight one is struck with the resem. blance which these birds bear to the Blackburnian Warbler, but on close inspection their identity is marked with habits peculiar to the bird. Between March 18 th and $24^{\text {th }}$ they appeared to be quite common, but after that date no specimens were seen.

83. Dendroica virens (Gmel.). (Black-throated Green Warbler). On March ISth, while beating my way through the mesquite bushes south-west of the town, I came upon a pair of these pretty birds in search of insects, which were evidently attracted by the pleasant fragrance which the blossoms of the bushes afforded. Slowly and in a zigzag direction the birds moved on, keeping up their restless motion without a moment's cessation. No signs of fear were shown only when a misstep was taken, which, for the moment, would startle them. Small Hymenopterous insects were found in the stomachs of those taken.

S4. Geothlypis trichas (Linn.). (Maryland Fellow- 
throat). Several of these birds were met with among the weeds and undergrowth in the western part of the city, March 26th.

85. Setophaga ruticilla (Linn.). (American Redstart). A few were seen March 26th, fifteen miles west of Corpus Christi. They were in dull plumage. No bright males were seen.

86. Mimus polyglottos (Linn.). (Mockingbird). On my arrival at Corpus Christi I was pleased to find the Mockingbird common. Its principal resort was among the chapparral, mesquite bushes, and brush fences which surrounded the Mexican farms on the western outskirts of the city. Many were seen in and about the town; they were also met with remote from human habitation.

Seldom do the Mockingbirds build a new nest; they generally reconstruct the one which was used the previous year. It is quite remarkable that the nests, which are composed mostly of mesquite and chaparral twigs, are but little distorted or broken by the storms and remain quite well preserved the year around. Their durability is in part due to the toughness of the material used and to the spines which project from the twigs, making the nests almost indestructible.

87. Harporhynchus longirostris (Lafr.). (Long-billed Thrasher). The morning after my arrival at Galveston I observed a bird of this species in a China tree in the heart of the city.

On March 2 Ist two birds were seen about six miles west of Corpus Christi among the ebony trees. Their wary habits would not allow us to approach within gun shot. April 8th a male and female, together with the nest, which contained three eggs, were taken two miles west of the city. The nest was built a few feet from the ground in a chaparral bush.

88. Thryothorus bewickil bairdi (Salv. \& Godm.). (Baird's Wren). While on a camping tour March 27th a male and a female of this species were taken. The incident relative to their capture I will quote from my note book: "While my assistant was engaged in the preparation of our dinner I busied myself taking a stroll to the oak timber which grew quite abundantly a few yards from the camp. On entering the woods the notes of the male were heard in the top hranches of a tall oak just a little to the left of the spot in which I was standing. A faint chattering sound was first noticed, then it became louder and harsher until I traced its source to the top branches, where, almost concealed by the thick foliage, the bird's form could be seen while hopping from twig to twig. From this position the specimen was shot, and I had no sooner laid it in my basket than the same chattering note greeted my ears from 
the other side of the camp. A long and tiresome search among the thick foliage was rewarded by a second specimen-the female." The notes uttered by these birds were evidently notes of alarm, for its real song is not unlike that of the Song Sparrow. A nest with six eggs was taken April igth.

S9. Troglodytes ä̈don parkmanil (Aud). (Parkman's Wren). Many were seen in the brush heaps near Mexican farms. 90. Regulus calendula (Linn.). (Ruby-crowned Kinglet). Only two of these birds were noticed during my stay. One was taken March 26th sixteen miles north of the city; the other was seen in the city March 25th.

91. Polioptila c.erulea (Linn.). Blue-gray Gnatcher). A number of these birds were taken March 2 Ist in mesquite bushes four miles west of the city. So numerous were they that I could scarcely look around without seeing the ends of the limbs borne down by the weight of their tiny bodies. The birds met with on this occasion seem to have been the bulk of a migratory flock, for, on visiting the locality several days later not a single specimen could be seen. 


\section{GEOGRAPHICAL VARIATIONS BETWEEN CHONDESTES GRAM- MACUS (SAY). AND CHONDESTES GRAMMACUS STRIGATUS (SWAINS.).}

BY H. K. COALE.

In Mr. Ridgway's Catalogue of North American Birds, I88r, page $6_{3}$, is this paragraph:

" Mr. H. K. Coale, of Chicago, Ill., has lately called my attention to certain differences between eastern (typical) and western specimens of this species, which, upon examination of a large series, I find to be quite constant and sufficiently appreciable to warrant the recognition of a western race. Western birds being exactly like those from Mexico in those points in which they differ from eastern specimens. Swainson's name strigatus (Chondestes strigatus, Philos. Jour. i. 1827,435$)$, based upon the Mexican bird, is available for the western and southern race."

On page 289 Swainson's Classification of Birds, 1836 , we find his definition of the genus

Chondestes Sw. Larkfinch. Fig. 263.

"Bill resembling Passerella, but the tip slightly inflexed and notched; the commissure considerably sinuated, and lobed in the middle. Wings lengthened, rather pointed; the three first quills nearly equal. Tail much rounded: the feathers broad, and the three outer graduated. Feet moderate. Hinder toe and claw much longer than the lateral toes, which are equal."

Dr. Coues does not admit the validity of the sub-species. Naturally opposed to varieties he has perhaps not taken pains to inquire into the matter.

With the material at hand*, I think you may soon be convinced that C. grammacus and C.grammacus strigatus are distinct.

Taking the Missouri River as the dividing line we find that birds from the west are larger, brighter about the head, and lighter above and below than those from the East-Ohio, Indiana and Illinois.

* Mr. Ridgway and Mr. Morcom kindly loaned me their specimens for examination. 
The following measurments are taken from five specimens of each:

Chondestes grammacus

of Chicago, H. K. Coale,

WING. TAIL. TARSI. BILL.

o St. Clair Co., Ill., H. K. Coale, $\quad 3.00$

$\begin{array}{lll}2.87 & .75 & .50\end{array}$

Independence, Mo., J. G. Cooper, . 3.37

$2.75 \quad .75 \div .50$

Columbus, O., H. W. Henshaw,

$3.00 \quad .75 \quad .50$

of Sioux City, Iowa, J. Feilusen,

$\begin{array}{llll}3.50 & 3.00 & .75 & .44\end{array}$

Average,

$3 \cdot 37$

$2.87 \quad .75$

.37

$\begin{array}{llll}3.3^{2} & 2.90 & .75 & .46\end{array}$

\section{Chondestes grammacus strigatus}

1 LaPaz, Cala., L Belding,

of Tucson, Ariz., E. W. Nelson,

f Corpus Christi, Tex., G. F. Morcom, .

ô Marysville, Cala., C. H. Townsend,

Clear Creek, Col., H. K. Coale,

Average,

- 3.62

3.50

3.37

.75

.50

3.50

3.25

.75

.56

$3.5^{\circ}$

3.00

.50

$\begin{array}{lll}3.25 & .75 & .50\end{array}$

$\begin{array}{llll}3.50 & 3.00 & .75 & .56\end{array}$

$\begin{array}{llll}3.5^{2} & 3.17 & .75 & .52\end{array}$

The above measurments, which are given in inches and hundredths, show the wing of the western birds to be twenty onehundredths of an inch longer than that of the eastern, and that the tail is twenty-five one-hundredths of an inch longer. The bills of the western birds are also a trifle longer than those of the eastern, while I have been unable to detect any difference in the length of the tarsi.

In grammacus the top of the head, back and middle tail feathers are very dark. The back is thickly mottled with black.

Strigatus is washed above with light brown, with narrow blackish-brown streaks. The markings on the head also differ. An Illinois 5 shows a black stripe .37 of an inch long back of the eye, which is wanting in from Arizona and California, and is nearly constant in the others. Young birds from Illinois and Utah show the same variation.

The genus is much more common West than East of the Missouri River. This may be partially accounted for by the fact that in Missouri and Southern Illinois, as well as some other localities, the farmers put paris-green on the plants to kill the potato-bugs, which, in this part of the country at least, form a large item of their food. In this way a large number of the birds are annually destroyed. 


\section{LIST OF BIRDS FOUND BREEDING WITHIN THE CORPORATE LIMITS OF MT. CARMEL, ILLINOIS.}

BY ROBERT RIDGWAY.

The writer's excuse for presenting this list is the circumstance that it pertains to a locality which has yielded to careful, though by no means protracted, explorition a decidedly large number of species of birds (about $2 \mathrm{SO}$, inclucling subspecies), than has been recorded for any other equal area in North America, and the exceptionally large number of specics $\left(S_{5}\right)$ which have heen found hreeding within the corporate limits of a moderately compact town within the area in question.

Large, however, as this number may appear in comparison with records for other places, it is believed that many localities in the Mississippi Valley presenting an equal variety of attractions for birds will be found no less favored.*

The town of Mount Carmel is situated upon a prominent bluff, the highest part of which is said to be I fo fect above low-water level of the Wabash River, and distant about a third, or perhaps half a mile from the river itself, here 1,000 to 1,200 fect wide. The river makes a bold sweep around two sicles of the town, flowing past the eastern, southeastem and southern portions, and the outline of the bluff, upon which the town is built, conforms strictly to the curve of the river.

The land between the town and the river was originally covered with heavy forest, but more than half a century having elapsed since the forest was felled, its place is now occupied by an open common, carpeted with the richest sward of bluc-grans and white clover, beautifully relieved here and there by mirror-like ponds and scattered clumps of trees, the latter mostly a second growth of honey locust, black and sweet gum, persimmon, black walnut, syca-

*Cf. "The Lower Wabash Valley, considered in its relation to the Faunal Districts of the Eastern Region of North America; with a Synopsis of its Avian Fauna," in Proc. Boston Soe. Nat. Hist. XVI. 1874 , pp. $304-332$; also, several papers, by E. W. Nelson and the writer in Bull. Nutt. Orn. Cl..b; American Naturalist; Bull. Esscx Invt.; etc. 
more, Michaux's oak and white elm, some of the latter being quite large and of the graceful dome-shaped type. Many of these trees, especially the smaller ones, are clensely canopied by wild grape vines. This open pasture land is divided into what are locally termed the "upper" and "lower commons," by an exceedingly crooked natural ditch known as "the slough," cut deeply into the earth, or down to low-water level of the river, here more than twenty feet below the general surface.

A portion of this so-called slough is almost beneath one's feet when observed from the gracefully rounded, though steep, front of the bluff, and from the same point of view may be seen the broad mouth of White River, gleaming between the solid walls of forest, which, standing flush with the bank, lines almost continuously the opposite shore; while about a mile below, the Patoka, a much smaller stream. enters the Wabash.

The Illinois shore is irregularly fringed with trees, some of them good-sized elms, cottonwoods, sycamores, and silver maples, while among them stand ware-houses, saw-mills, and other belongings of a river town.

The "commons" are succeeded both above and below by cultivated fields, and these in turn by woods, which a comparatively few years ago were in an almost primitive condition, but which of late years have been much thinned out by the clearing of considerable areas and the destruction for saw-logs of the best trees upon the remaining portions. On the opposite side of the town, meadows of grass or clover, and fields of wheat or corn alternate with open groves and bits of enclosed woodlind, consisting (as does the sylva of the entire country) of various hard-woods; while the town itself is embowered in a wealth of foliage-orchards and shade trees, with gardens and shrubbery in profusion.

Within the town limits were formerly several small, though secluded marshes, in which dwelt various water birds and other species affecting such localities, but these, with one or two exceptions, have since been drained.

The total number of species positively identified to date as found at one time or another within one mile of the center of the town is $28 \mathrm{r}$, some of them being, as a matter of course, rare, irregular, or even accidental in their occurrence. Of this number 73 species are transient, passing through in Spring and Fall; $7+$ are permanent residents, or may occur at any season of the year; S6 appear only in Summer, while $4 S$ are present only in Winter. The 
total number ascertained to breed within the same area is about $\mathbf{1 4 0}$, of which, no less than $8_{4}$ have been positively identified as breeding within the town limits, which are three square miles in extent. The following is a complete list:

I. Ardea virescens Linn. (Green Heron). Nesting in one or two localities within the town limits.

2. Rallus elegans Aud. (King Rail). Breeding in at least two localities within the town, one of these places was some years since obliterated by drainage. In this place, not more than half a mile from the court house, a nest containing eleven eggs was found.

3. Porzana carolina (Linn.). (Sora Rail). Observed during the breeding season and probably nests in the few suitable localities.

4. Philohela minor (Gmel.). (American Woodcock). Rare, but found in a few suitable places.

5. Totanus solitarius (Wils.). (Solitary Sandpiper). Common and undoubtedly breeding.

6. Actitis macularia (Linn.). (Spotted Sandpiper). Common, but confined chiefly to the river bank.

7. Egialitis vocifera (Linn.). (Killdeer). Not uncommon where suitable localities occur.

8. Colinus virginianus (Linn.). (Bob-white). Common in outlots.

9. Zenaidura macroura (Linn.). (Mourning Dove). Common everywhere.

Io. Coccrzus americanus (Linn.). (Yellow-billed Cuckoo). Rather common in orchards.

in. Coccyzus erythrophthalmus (Wils.). (Black-billed Cuckoo). Much less numerous than the preceding, but usually found with it. On one occasion a nest, with eggs, of each of these species was found upon adjoining trees in an orchard.

12. Cerile alcyon (Linn.). (Bclted Kingfisher). Common along the river bank, and also nesting in the "dug road" along with the Bank Swallows.

I3. Dryobates villosus (Linn.). (Hairy Woodpecker). Rare, but occasionally found breeding in orchards and elsewhere.

14. Dryobates pubescens (Linn.). (Downy Woodpecker). The same remarks apply to this as to its larger cousin.

15. Meinanerpes erythrocephalus (Linn.). (Red-headed Woodpecker). Much the most numerous species of the family. In 
Summertime these frolicsome birds frequent the spire of a church in the center of the town, and amuse themselves by tapping on the tin globes of the weather vane.

i6. Melanerpes carolinus (Linn.). (Red-bellied Woodpecker). Common, though seldom breeding far within the town.

17. Colaptes auratus (Linn.). (Flicker). Common. One nest found in an orchard not far from the court house.

I8. Antrostomus carolinensis (Gmel.). (Chuck-rvill'swidow). Very rare in woods just within the town limits.

19. Antrostomus vociferus (Wils.). (Whip-poor-will). The same remarks apply to this as to the preceding. Both are common further from the town.

20. Chordeiles virginianus (Gmel.). (Nighthawk). Rare within the town limits.

21. Chetura pelagica (Linn.). (Chimney Swift). Perhaps the most numerous of all the birds of the neighborhood.

22. Trochilus colvbris Linn. (Ruby-throated Hummingbird). Common.

23. Tyrannus tyrannus (Linn.). (Kingbird). Common in orchards, but partial to isolated cottonwood or sycamore trees.

24. Myiarchus crinitus (Linn.). (Crested Fly'catcher). Rather rare in the town, but several pairs nest in hollow apple trees or in Martin boxes. One pair nested for one or more seasons in a window of the jail, the nest being placed behind the iron bars of the window.

25. Sayornis phebe (Lath.). (Phobc). Common.

26. Contopus virens (Linn.). (Wood Pewee). Common. Nesting occasionally in orchards, but usually in large shade trees.

27. Empidonax Acadicus (Gmel.). (Acadian Filycatcher). Rather common in suitable localities (thickets or under woods along the water courses).

28. Empidonax pusillus traillit (Aud.). (Traill's Flycatcher). More rare than the preceding, but found in much the same localities.

29. Otocoris alpestris praticola Hensh. (Prairie Horned Lark). Common, chiefly confined to open pasture ground.

3o. Cyanocitta cristata (Linn.). (Bluc Fay). Abundant. Nesting in shade trees along the principal street and in orchards throughout the town.

31. Molothrus ater (Bodd.). (Cowbird). Common. 
32. Agelaius pheniceus (Linn.). (Red-winged Blackbird). Abundant in suitable places.

33. Sturnella magna (Limn.). (Meadowlark). Abundant.

34. Icterus spurius (Linn.). (Orchard Oriole). More numerous than the Baltimore, but almost entirely confined, as its name indicates, to apple orchards.

35. Icterus galbula (Linn.). (Baltimore Oriole). Common.

36. Quiscalus quiscula eneus (Ridgw.). (Bronzed Grackle). Abundant, but most of their former breeding places (large elm trees containing cavities) are now destroyed.

37. Spinus tristis (Linn.). (American Goldfinch). Breed${ }^{i}$ ng sparingly in small trees, especially along the roadside in outskirts of the town.

38. Poocktes gramineus (Gmel.). (Vesper Sparrow). Less rare than the following, though still by no means common.

39. Ammodiamus sandwichensis savanna (Wils.). ( $S a$ vanna Sparraw). Very rare in summer. Two or three have been positively identified. Nests found in damp meadows.

40. Ammodramus savannarum passerinus (Wils.). (Grasshopper Sparrow). Abundant in dry meadows.

41. Ammodramusinenslowir (Aud.). (Henslow's Sparrow). Common in damp, weedy meadows.

42. Chondestes Gramacus (Say). (Lark Sparrow). Abundant in the outlots.

43. Spizella socialis (Wils.). (Chipping Sparrow). Abundant everywhere.

44. Spizella pusilla (Wils.). (Field Sparrow). Abundant in bushy places in the outskirts.

45. Peucea estivalis Bachanil (Aud.). (Bachman's Sparrow). Rather rare and confined to a few particular localities, but originally discovered and undoubtedly breeding within the town limits.

46. Pipilo erytirophthalmus (Linn.). (Towhee). Common in bushy places in the outskirts.

47. Cardinalis cardinalis (Linn.). (Cardinal). Common in all suitable places. Several pairs breeding in cedar trees in the middle of the town.

48. Passerina cyanea (Linn.). (Indigo Bunting). Abundant in suitable places.

49. Spiza americana (Gmel.). (Dickcissel). Probably the 
most abundant of all the Fringillida. Found in all meadows, but particularly partial to clover fields.

50. Piranga erythromelas Vieill. (Scarlet Tanager). Much less common than P. rubra during the breeding season. Also more partial to damp woods in creek bottoms, etc.

51. Piranga Rubra (Linn.). (SummerTanager). Common in oak groves.

52. Progne subis (Linn.). (Purple.Martin). Abundant. One resident of the town regarded these birds with so much favor as to provide numerous boxes for their accommodation. His hospitality was availed of by a colony of several dozen pairs, who, in return, undoubtedly did much service in lessening the number of insect pests about his premises.

53. Petrochelidon lunifrons (Say). (Cliff Swallow). A large colony of this species at one time built their nests underneath the eaves of the Presbyterian Church, and, on another occasion, under those of an old barn in the middle of the town.

Persecution resulting from the peculiar instincts of the numerous "small boy," howerer (the writer among the number), interfered sadly with their domestic affairs; yet, with remarkable persistence, they rebuilt their nests as fast as they were demolished, and thus, under trying circumstances, succeeled in rearing a numerous progeny. Colonies have also been observed about barns in the country.

54. Chelidon erytirogaster (Bodd.). (Barn Swallow). Single pairs nest in various old barns and unused stables.

55. TAchycineta Bicolor (Vieill.). (Tree Swallow). Nested in holes of several dead-topped elms which formerly grew upon the banks of the "slough" near the foot of the bluff. Formerly bred very numerously in deserted woodpeckers' holes in dead snags and stumps near the dam.

56. Clivicola riparia (Linn.). (Bank Swallow). Nesting in holes in the sandy banks of a graded street, known as the "dug road," in company with the Rough-winged Swallow and Kingfisher; also in various other locaiitics within the town limits.

57. Stelgidopteryx serripexis (Aud.). (Rough-winged Swallow). Much more numcrous than the preceding, but usually found in company with it, or in similar localities in colonies by themselves. All nests of this species which I have found at Mt. Carmel, were in holes in banks, though I have no doubt that they there sometimes deviate from this their usual custom. 
58. Ampelis cedrorum (Vieill.). (Cedar Waxwing). Very scarce in summer, but young not long from the nest have been shot.

59. Lanius Ludovicianus Linn. (Loggerhead Shrike). Common. Many nests found in orchards, but many more in the smaller honey locust (Gleditschia triacanthos) trees on the commons and along roadsides, the trunks and branches of these trees being densely armed with frightful thorns, rendering access to the nests by climbing an impossibility.

6o. Vireo olivaceus (Linn.). (Red-eyed Vireo). Breeding sparingly in groves and other woods in the outskirts.

61. Vireo gilvus (Vieill.). (Warbling Vireo). Not rare among shade trees throughout the town.

62. Vireo noleboracensis (Gmel.). (White-eyed Vireo). Common in the hazel thickets and brier-patches in the outskirts.

63. Protonotaria citrea (Bodd.). (Prothonotary Warbler). A few nests of this species have been found in the vicinity of ponds (the then existing woods having since been cleared) be tween the town and the river.

64. IIelimenthopima pinus (Linn.). (Blue-winged Warbler). The first nest I ever found of this species, and the first of which there is any authentic record, was found in the bushy and partly cleared corner of a field well inside the town.

65. Dexirotca estrira (Gmel.). ( Yellow Warbler). One of the most abundant species, especially in orchards.

66. Dexdroica c.erulea (Wils.). (Cerulean Warbler). Breeding within the town limits in low wooded places, being abundant in woods of bottom lands along the river.

67. Dexdroica dominica Albilora Baird. (Sycamore Warbler). Rather common in trees along the river bank.

6S. Seiurt's aurocapillus (Linn.). (Oven-bird). Common in the groves in the outskirts.

69. Seiurus motacilla (Vieill.). (Louisiana WaterThrush). Always to be found in certain suitable localities.

7o. Geothlypis formosi (Wils.). (Kentucky Warbler). Common in all damp, rich woods.

7i. Geothlypis trichas (Linn.). (Maryland Yellowthroat). Found wherever there are brier-patches or other localities suited to its habits.

72. Icteria virexs (Linn.). (Yellow-breasted Chat). 
Found in the same localities as the Field Sparrow, Indigo Bunting, Maryland Yellow-throat and White-eyed Vireo.

73. Setophaga Ruticilla (Linn.). (American Redstart). Breeding sparingly in groves and other woods in the outskirts.

74. Mimus polyglottos (Linn.). (Mockingbird). Rare. One or two pairs breed within the town limits nearly every season.

75. Galeoscoptes carolinensis (Linn.). (Catbird). Abundant in orchards and door yards. One of the most numerous species.

76. Harporhynchus rufus (Linn.). (Brown Thrasher). Common in outskirts and occasional in orchards.

77. Thryothorus ludovicianus (Lath.). (Carolina Wren). A few pairs breed every Summer in the town, but the principal haunts of the species are the woods, especially in bottom lands.

78. Thryothorus Bewickir (Aud.). (Bewick's Wren). Abundant. Nesting about almost every habitation in the town. I do not remember having ever seen a specimen of this species outside of the town, except in a few instances where a pair had taken up their abode about the stable or other out buildings of some farm house.

79. Sitta Carolinensis Lath. (White-breasted Nuthatch). Rather rare during the breeding season, only one nest having been found within the corporation limits.

8o. Parus bicolor (Linn.). (Tufted Titmouse). Common in orchards and groves.

81. Parus Carolinensis Aud. (Carolina Chickadee) Common about the outskirts of the town but more rare in orchards within the town limits.

82. Polioptila C.erulea (Linn.). (Blue-gray Gnatcatcher). Several nests found within the town limits, but only in the outskirts in oak trees.

83. Turdus mustelinus Gmel. (Wood Thrush). Common in damp woods.

84. Merula migratoria (Linn.). (American Robin). One or two pairs in nearly every orchard, also in shade trees and in large elms on the outskirts of the town.

85. Sialia sialis (Linn.). (Bluebird). Common, nesting in hollows of apple or shade trees, about houses, etc.

In this connection a comparison with a locality of nearly corresponding latitude on the Atlantic coast-Washington, D. C.,-may be of interest. 
The number of species found breeding in Mt. Carmel, but not in W ashington, or immediate vicinity, is fourteen, as follows:

I. Thryothorus beWickil (Aud.). (Bervick's Wren).

2. Protonotaria citrea (Bodd.). (Prothonotary Warbler.)

3. Dendroica cerulea (Wils.). (Cerulean Warbler).

4. Dendroica dominica Albilora Baird. (Sycamore Warbler).

5. Lanius Ludovicianus Linn. (Loggerhead Shrike).

6. Ammodramus sandichensis savanna (Wils.). (Savanna Sparrow).

7. Chondestes grammacus (Say). (Lark Sparrow).

8. Peucata estivalis Bachmanil (Aud.). Bachman's Sparrow.

9. Quiscalus quiscula eneus (Ridgw.). (Bronzed Grackel).

io. Octocoris alpestris practicola Hensh. (Prairie Lark).

ir. Empidonax pusillus trailiti (Aud.). (Traill's Flycatcher).

I2. Antrostomus carolinensis (Gmel.). (Chuck-will'swidow.)

13. Rallus elegans Aud. (King Rail).

I4. Porzana carolina (Linn.). (Sora Rail).

The species which have been ascertained to breed in the vicinity of Washington, D. C., but not at Mt. Carmel are only seven in number, being the following:

I. Troglodytes A Ëdon Vieill. (House Wren).*

2. Denidroica discolor (Vieill.). (Prairie Warbler).*

3. Melospiza fasciata (Gmel.). (Song Sparrow).

4. Guiraca carulea (Linn.). (Blue Grosbeak).*

5. Quicalus quiscula (Linn.). (Purple Grackle).

6. Corvus ossifragus Wils. (Fish Crow).

7. Strix pratincola Bonap. (Barn Owl).*

By extending the boundaries of Mt. Carmel, however, so as to take in an equal area of the circumjacent country as has been done in the case of Washington, the preponderance in favor of the former locality would be still greater, since the following would require to be added to the fourteen species named above: 
15. Helinata swainsonir Aud. (Swainson's Warbler).

16. Compsothlypis americana (Linn.). (Parula War. . bler).

i7. Sylvania mitrata (Gmel.). (Hooded Warbler).

18. Ceophleus pileatus (Linn.). (Pileated Woodpecker).

19. Falco peregrinus anatum (Bonap.). (Duck Hawk).

20. Ictinia mississippiensis (Wils.). (Mississippi Kite).

21. Catharista atrata (Bartr.). (Black Vulture).

22. Nycticorax nycticorax nevius (Bodd.). (Black. crowned Night Heron).

23. Nycticorax viol aceus (Linn.).( Yellow-crowned Night Heron).

24. Ardea herodias Linn. Great Blue Heron.

25. Porzana noveboracensis (Gmel.). ( Yellow Rail).

26. Porzana jamaicensis (Gmel.). (Black Rail).

27. Lophodytes cucullatus (Linn.). (Hooded Merganser).

28. Phalacrocorax dilophus floridanus (Aud.). (Florida Cormorant.

29. Podilymbus podiceps (Linn.). (Pied-billed Grebe).

It may be added that when the vicinity of Mt. Carmel shall have been as thoroughly investigated as have the environs of Washington, the number of species found breeding there will be considerably increased. As the enumeration stands, however, the difference is as follows:

Number of species breeding in the vicinity of Mt. Carmel, III., 122.

Number of species breeding in the vicinity of Washington, D. C., 106. 
NOTES ON THE BIRDS OF SOUTHERN CALIFORNIA AND SOUTH-WESTERN ARIZONA.

BY G. FREAN MORCOM.

The material on which the present paper is based, was obtained during a three months' collecting trip made by Mr. F. Stephens (for the writer), in the Spring and early Summer of 1886.

Mr. Stephens was instructed to make the object of the expedition, not so much the accumulation of specimens, as of facts regarding the habits of the birds observed. The results are given in his own words:

It will be necessary to a thorough understanding of the following notes, for me to call your attention to the general topography of that section of the country in which my collecting was done.

My first collecting was done in the Cohuilla Valley between April Ist and I 9 th. I was encamped at a locality known for many years as "Agua Caliente," but there are other springs, even in the same county (San Diego), known by the same name. This place has been lately called "Palm City" (a town-site having been laid out by speculators), but the name is not, nor is it likely to become, widely known.

The term "Colorado Desert" is correct enough, but the Desert includes too much country for that term to give any definite idea of my locality, which was more than one hundred miles from the Colorado River, which river may be called the eastern limit of the Desert.

The south-western part, in which I was located, is inhabited by the Cohuilla Indians, hence the name of the valley. There is also a small valley of the same name in the mountains near by, but it is only known locally. What is here called the Cohuilla Valley is the narrow part of the Desert beginning at the San Gorgonio Pass and ending at the Indian village of Toros, which is about forty miles E. S. E. from San Gorgonio Pass. The valley is from five to ten miles wide and is a dry, sandy desert, barren-except for the cacti, larrea bushes, etc.,--save around the warm springs and at the mouths of the canous where a stream of water may flow for a few weeks in the spring.

At the west end San Jacinto Peak rises abruptly from the plain 
to an altitude of over 9,000 feet. At the summit of this peak snow may be found all the year, while at the warm springs, less than ten miles away, snow is hardly seen once in a century. In fact, I know of no place where stronger climatic contrasts occur. The altitude of the springs is about 100 feet, but a considerable portion of the valley is below the sea-level.

From April 2oth to 23d I collected near Banning, a town near the upper part of San Gorgonio Pass. It is on the eastern edge of a grain-growing country and its altitude is about 2,500 feet. To the North and South the hills are covered with a thick growth of low bushes, leaving between them a plain, or valley, some two miles wide. The road between Banning and San Bernardino passes through grain fields to the top of the Pass, (Here is the town of San Gorgonio, altitude 2,90o feet), thence through the San Mateo canon.

I expected to do a month's work near Yuma, Arizona, but, owing to a freshet in the Colorado River, which overflowed the bottom lands, I had to be content with half that time, being there from May $3^{d}$ to $5^{\text {th }}$ only.

Yuma is on the Colorado River and is in the midst of a desert country, barring, of course, the ever present cacti. The mesquite in this country is but a scraggy tree, willows are plenty along the river, but are mostly small saplings growing very thickly. There are also a few cottonwoods.

From Yuma I went to the mountains about ten miles north of the Southern Pacific R. R. station of San Gorgonio and at an altitude of 4,500 feet; here I stayed from May 25th to $3^{\text {Ist. }}$

The immediate vicinity is well timbered with sycamores and live oaks, with here and there a fir, while only a little higher up the mountain sides is the pine belt. About a mile away and at an altitude of not more than 6,500 feet, snow was seen in a few places in the deep gulches (May 28th).

From San Bernardino to Bear Valley, where I collected from June $7^{\text {th }}$ to 28 th, the road passes through the Cajon Pass, thence across the Mojave Desert to Rabbit Springs, while a little further along you strike into the mountains. At Cajon Pass I stopped three days (June $3^{\text {rd } \text { and }} 4^{\text {th }}$ and July ist).

Bear Valley is an elevated plateau two or three miles wide by fifteen long and is at an altitude of from 7,000 to 8,000 feet. It is surrounded by mountains from 500 to $\mathrm{I}, 000$ feet higher, and is well timbered with pine except through the center, which is more or 
less of a grassy plain. Here also are two bodies of water, the upper, called Bear Lake, is about a square mile in extent and is formed by the melting of the Winter's snowfall, which is usually very heavy. In dry years the Lake nearly disappears.

The lower body of water is artificial, an irrigating company having built a fine stone dam across the outlet of the valley, forming what is known as the Bear Valley Reservoir, which now covers some two thousand acres.

This valley is separated from San Bernardino and Grayback Peaks by a lower, broken, heavily timbered region, in which are the headwaters of the Santa Ana River. It is inaccessible by wagon, and the few trails are rough and steep.

The view south and south-east from the ridge south of Bear Valley is very fine; below lies a trough-like depression, some ten miles wide in front, widening and rising toward the east and nearly closed at the lower end by spurs from the mountain ranges on either side. Its lower (central) part is 4000 to 5000 feet lower. Throughout it is a massive, dark-green, coniferous forest, with here and there an extensive patch of chaparral on the southern exposure.

In the south, some ten miles distant, is San Bernardino Peak, which, as seen from the San Bernardino Valley, is only a peak, but from here it is seen to be a range of mountains of nearly equal height and nearly twenty miles long, finally culminating in Grayback Peak, which has an altitude of I I, 300 feet. The whole crest of the range for a mile from the summit was an almost unbroken field of snow in June, 1886.

i. Colymbus nigricollis californicus (Heerm). (American Eared Grebe). Not uncommon on the lakes in Bear Valley. I think there are two species of grebes here, but was unable to positively identify but this one. They breed in June.

2. Anas boschas Linn. (Mallard). Saw several on the lakes in Bear Valley, where they breed.

3. Anas cyanoptera Vieill. (Cinnamon Teal). A pair of these birds was obtained in Cohuilla Valley; they were the only ones seen here. The species should occur commonly during the migrations. At Bear Valley I found them not uncommon. They breed along the coast.

4. Aythya americana (Eyt.). (Redhead). Saw one pair on the lake in Bear Valley June $13^{\text {th. }}$

5. Erismatura rubida (Wils.) (Ruddy Duck). Common on the lakes in Bear Valley. They breed in June. 
6. Plegadis guarauna (Linn). (White-faced Glossy Ibis.) This bird is not particularly rare in this section of the country, being found near streams and ponds. One was taken in Cohuilla Valley April i 2th. Iris dull, dark-red.

May 3 rd a flock came about the sloughs on the Gila River above Yuma. They were so wild that I could not get near them, and $I$ at last tried a very long shot across a slough, fortunately winging one. As they were flying about I heard an occasional harsh, heron-like note. The ovaries of the one shot were greatly enlarged.

7. Tantalus loculator Linn. (Wood Ibis). This species occurs as a straggler in the San Bernardino Valley in Summer. Only one noted, that at Yuma, May 3 rd.

8. Rallus virginianus Linn. (Virginia Rail) This is not a common bird in this part of the country. Only one was noticed; Cohuilla Valley April 5th.

9. Porzana carolina (Linn.). (Sora). This species occasionally stops at the ponds in Cohuilla Valley during the migrations. One was taken April 3 rd, another was seen in Bear Valley June $13^{\text {th. }}$.

Io. Fulica americana Gmel. (American Coot). They breed abundantly on the lakes in the Bear Valley. I found one nest containing twenty-two eggs, it was probably a community nest.

The nests are generally built of dead rushes, etc., and are placed on tufts of grass growing in the water or on masses of driftwood near the water's edge.

I 1. Gallinago delicata (Ord.). (Wilson's Snipe). Rare. A $q$ of this species shot in Cohuilla Valley, April 2 nd, is the only one noted.

12. Egialitis vocifera (Linn.). (Killdeer). Common everywhere.

i3. Oreortyx pictus plumiferus (Gould). (Plumed Partridge). One was shot near San Gorgonio May 28th. They were not uncommon in Bear Valley, where several were taken. Young were seen on June 22 nd.

I4. Callipepla californica vallicola Ridgw. (Valley Partridge). Not common in the Cohuilla Valley. A $\&$ taken April I 7 th, contained eggs ready to be laid. Their stomachs were well filled mostly with caterpillars, but also contained a few seeds.

15. Callipepla gambeli (Nutt.). (Gambel's Partridge). 
This species is not uncommon in the Cohuilla Valley, and at Yuma I found them quite common. On the I Ith of May, a young Indian brought about five dozen of them into Yuma, he had snared them alive, and I got a selected dozen of them for one dollar. Does not occur at San Bernardino or Bear Valley.

16. Melopelia leucoptera (Linn.). (White-winged Dove). Only two seen, these at Yuma May I5th. They were flying rapidly and crossed the Colorado River. Does not occur west of the Colorado Valley.

17. Pseudogrymus californianus (Shaw). (California Vulture). At Banning, on April 22nd, while engaged in skinning birds I heard the croaking of approaching Ravens, and, looking up I saw two, pestering what I thought was a Golden Eagle. Snatching my rifle, I fired as they passed at a distance of about I 50 yards with no other effect than to frighten off the Ravens.

As the other bird resumed its flight I saw to my astonishment, that it was a small California Vulture. I slipped in another cartridge and fired again, but with no better success than at first. There was no white about the tail nor under the wings, but the front edge of the wing, from the shoulder to the carpus, had a narrow edging of white. The head was very pale, almost white apparently. The extent of wings was not over seven feet I think. It was most probably a young bird not nearly grown.

June 7 th, while in Bear Valley, I saw another, this was also an immature bird. On June 8th, I saw another passing over; this one was flying very straight and high, presently three more appeared in the wake of the first, those, in turn, being followed by a train of Turkey Buzzards (Cathartes aura).

Two more were seen in this locality June $15^{\text {th. They passed }}$ over at an elevation of 800 or Iooo feet. I fired at them with the rifle, but ineffectually.

is. Cathartes aura (Linn.). (Turkey Buzzard). Some seen in Bear Valley, June 8th. Common.

i 9. Accipiter cooperi (Bonap.). (Cooper's Hawk). Three seen May $r 7^{\text {th }}$ and 18 th, at San Bernardino.

20. Buteo borealis calurus (Cass.). (Western Red-tail). Not common anywhere. One seen at Yuma, one at Riverside and several in Bear Valley.

21. Buteo Swainsoni Bonap. (Swainson's Hawk). It was reported to me that this bird flies over Riverside in small numbers every evening during April and May, going from the plains 
to the cottonwoods in the river bottoms. I saw but two, both in the San Bernardino Valley. Breeds.

22. Archibuteo ferrugineus (Licht.). (Ferruginous Rough-leg). A large, light-colored hawk which, I think, is referable to this species, was seen in the barren, rocky hills near Yuma, May 15th. It was too wary to admit of an approach. The species is a rare Winter visitant in Southern California.

23. Falco sparverius Linn. (American Sparrow Hawk). Common everywhere.

24. Strix pratincola Bonap. (American Barn Owl). Not uncommon in the San Bernardino Valley. The stomachs of those shot contained fur and bones of several small animals, among which were the Harvest Mouse (Ochetodon longicauda), the Gopher (Thomomys tolpoides bulbivorus), and also the Meadow Mouse (Arvicola riparia).

25. Asio wilsonianus (Less.). (American Long-eared Owl). On April 1st, one was shot in the Cohuilla Valley. It was found in the low brush near the sink of the stream below the spring. The stomach contained the skulls and other remains of two Tufttailed Pocket Mice (Perognathus penicillatus).

26. Speotyto cunicularia hypogea (Bonap.). (Burrowing Owl). Common in San Bernardino Valley. None were noted elsewhere. Stomachs contained Beetles, Harvest Mice (Ochctodon longicauda), and Pocket Gophers (Thomomys tolpoides bulbivorus).

The hind quarters of a Kangaroo Rat (Dipodomys phillipsi) were found at the entrance to one of their burrows.

27. Geococcyx californianus (Less.). (Road-runner). Rather common. A young of was taken from the nest in San Gorgonio Pass, May 27th. The nest was placed in a cholla cactus about three feet from the ground, also contained two eggs in which incubation was advanced.

28. Dryobates villosus harrisir (Aud.). (Harris's Woodpecker). A i shot at Bear Valley, June 8th.

29. Dryobates scalaris (Wag.). (Texan Woodpecker). None seen except at Yuma, where they are quite rare.

30. Dryobates nuttalli (Gamb.). (Nuttall's I'oodpecker). Not common. Three were taken at San Bernardino in May.

31. Xenopicus albolarvatus (Cass.). (White-headed Woodpecker). Not uncommon in Bear Valley. Specimens-both 
males and females-taken about the middle of June show signs of having incubated.

32. Melanerpes formicivorus bairdi Ridgw. (California Woodpecker). Common near San Gorgonio. A nest found May 3 oth contained two young birds and three addled eggs, two more young had just left the nest. Iris white, tinged with red.

33. Melanerpes uropygialis (Baird). (Gila Woodpecker). Found only at Yuma, where they were not common. A nest found May 4th was excavated in a growing willow on the edge of a slough. Eggs three; incubation commenced. The $q$ was very solicitous about her nest, and would not leave the tree in which it was built.

Woodpeckers are not common at Yuma, probably owing to the timber being too small to furnish nesting sites. Colaptes chrysoides has been taken here, but is probably only a straggler.

34. Colaptes cafer (Gmel.). (Red-shaftcd Flicker). Common. With this species the male incubates as well as the female.

35. Chordeiles texensis Lawr. (Texan Nighthawk). Noted at Yuma and in Bear Valley. Is by no means common, only four being taken. Aq obtained May $5^{\text {th }}$ was nearly ready to lay.

36. Micropus melanoleucus (Baird). (White-throated Swift). Rare, especially northward. Two o taken April roth and 19th in Cohuilla Valley.

37. Trochilus alexandri Bourc. \& Muls. (Black-chinned

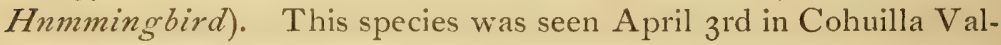
ley; they were most common on the $13^{\text {th }}$, when they were found in company with $T$. costce, $T$. rufus, and $T$. alleni. They are only migrants in this locality. One $\hat{f}$ was taken at Yuma, May 5th. In the San Benardino Valley they are not uncommon and breed. A nest taken May 22nd, was built in a willow eight feet from the ground and contained two eggs in which incubation had commenced. None were seen in Bear Valley.

38. Trochilus costa (Bourc.). (Costa's Hummingbird). On the 3 rd of April, while passing a bush in the Cohuilla Valley a $q$ of this species was observed to fly out in such a manner as to make me think she had a nest near by. In a few minutes she returned, and, after hovering around a little, settled on the nest. It was built in a bush of Larrea mexicana about two feet from the ground and contained two fresh eggs. The $q$ was afterwards shot. 
On the 9th, another nest was discovered in the same way. This time it was built in a greasewood three feet from the ground and contained two eggs in which incubation was commenced.

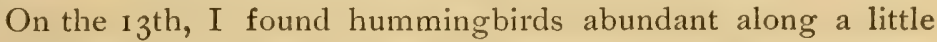
stream at the base of the mountains. Three-fourths of those seen were $q$, and, apparently $T$. Costce. All were in active motion so that it was difficult to get such as I wanted. $T$. rufus and $T$. alleni were pugnacious as usual but costce held its own well. The $q$ were sharp tempered too, as if the excitement of moving had had its usual effect. The next day alleni and rufus were all gone, alexandri, however, still remained, though coste was still in much greater number.

The $q$ of the latter species keep up a pretty constant vocal noise while feeding, which somewhat resembles the buzz of their wings. The feeding note of the $\hat{o}$ is finer and not as frequently heard.

The note of $T$. alexandri, both $\hat{s}$ and $\rho$, is similar to that of the $q$ costce. I have heard the song of each, but it was some time since, and, as I remember it, there was little difference between the two species. I think that the males are the only ones who sing. The song is sweet and very low, but if it is perfectly quiet around, it can be distinctly heard for a distance of ten yards. As might be expected from the size of the bird, it is on a very high key, something like the sound produced by whistling between the teeth, very low, yet at a high pitch. It might be called a warble and I have heard it kept up for several minutes at a time. At such times I have never been able to find $\mathrm{a} q$ in the vicinity and have come to the conclusion that it was sung for the individuals own amusement.

The courtship-song, if such it may be called, is a very different affair. We will take $T$. costce for example: the $q$ is setting on a twig in a low brush, not on an exposed twig as is often the case when she is merely resting, but when the of begins she goes further in, as if she feared that he really intended mischief, while he rises high in the air, and, with a headlong swoop, comes down, passing her and turning with a sharp curve as near her as is possible mounts on high to repeat the mancuvre again and again. A shrill whistle is heard as he begins to descend, starting low and becoming louder and louder, until, as he passes her, it becomes a shriek which is plainly audibly for a distance of 100 yards or more. As he mounts again it dies away only to be repeated at the next descent. This is a common manœuvre with the species. 
For a long time I was unable to decide whether the sound was vocal or mechanical, as it at first seemed as if the increase in volume and pitch of the sound was due to the increased velocity of the descent, especially so as the sound died away when he rose, but I now believe it to be purely vocal.

Their velocity at such times is very great, so great that should the bird accidentally strike a branch he would not only be killed, but undoubtedly torn to pieces. I can compare it to nothing but the swoop of the Falcon, and I think that the velocity of the hummer at such times at least equals that of the Falcon. The eye cannot keep track of the bird at the lower part of the curve-with some practice I was able to keep him in sight through all the rest of the circle, but, as he came down faster and faster, I lost him, only to spy him again when he had risen a short distance.

I have watched quite a number this Spring and all of them seem to go over the same course as nearly as possible. Some rise much higher than others, the extreme height being some 400 feet and the minimum 40 to 50 feet, with an average of about 200 feet. The number of swoops per minute varies from two to ten (approximately).

I have three times seen $f$ of $T$. alexandri go through a similar performance. Twice the $q$ was sitting on an exposed twig when the $\hat{s}$ swung back and forth before her, meanwhile giving vent to a peculiar bee-like buzzing sound. This swing was nearly horizontal and only three or four feet in extent. On the other occasion the $q$ was sitting in the shelter of a mesquite, the $f$ rose 30 or 40 feet in the air, sweeping down again like $T$. costce but, instead of passing on overhead and thus completing the circle, he swung back through an arc, reversing his direction at each end.

The sound, like that of coste, increased as he descended and died away again as he rose. It was not, however, quite as shrill as with costce, and as it became loudest it became tremulous, like the tremolo of an organ. This tremulous quality proves its vocal origin. As it was impossible to tell the species in its active motions and as the note was new to me I carefully kept him in view until he alighted, when I shot him.

On June $23 \mathrm{rd}$, I witnessed the swooping manœuvre of $T$. calliope. He did not rise far after his downward plunge, but reversed his direction, flying back over the same track as in the downward swoop, then reversing again, he flew higher. He made but two or three passes. 
The whistle made during his descent was quite low and the buzzing sound made as he passed the other bird, a young $T$. costa, was coarser than I had heretofore thought. It also lacked all whistling character. I also noticed another swooping back and forth, but heard no whistle or other vocal sound.

There is still another hummer-note--that of the chase. They are very fond of chasing one another, sometimes for sport, often for spite. This note also resembles the feeding note, but is louder and possesses a chippering character, sometimes almost like the sound produced by lightly and rapidly smacking the lips together. I can detect but little difference between the sexes and it appears much the same whether the chase is in sport or in anger. Furthermore, it is often made by the pursued as well as the pursuer. At such times I am always reminded of a lot of school-boys playing tag.

If a hummer is perched and a person passes near they start off, uttering a note similar to that made while feeding, but, should it be a $q$ which you have frightened from her nest she will go off silently.

Several, both old and young, were taken at San Bernardino, and at Bear Valley a number of young were observed. These last had most probably migrated here from below.

39. Trochilus rufus Hmel. (Rufous Hummingbird). Common during the migrations. Do not breed so far south as San Bernardino.

40. Trociulus alleni (Hensh.). (Allen's Hummingbird). The same remarks apply to this as to the preceding.

41. Trochilus calliope Gould. (Calliope Humming. bird). Not uncommon. They were most numerous in Bear Valley, where I took three adult $\hat{\delta}$, two young $q$ and three young $\hat{\delta}$ in three days. I was unabe to find any adult $q$ of this species. The adult $\delta$ all stay around the mouths of the canons in Bear Valley, not seeming to ascend them.

42. Trrannus verticalis Say. (Arkansas Kingbird). Common everywhere but at Yuma. Took young on the Mojave river June 29 th.

43. Myiarchus cinerascens Lawr. (Ash-throated Flycatcher). Only two noted. San Bernardino, April 27th, and Bear Valley, June 3oth.

44. Sayornis nigricans (Swains.). (Black Phabe). A common bird in nearly all localities. None noted at Yuma, although they undoubtedly occur there. 
45. Contopus borealis (Swains.). (Olive-sided Flycatcher). This species is a rare migrant in Cohuilla Valley and is not common in any part of this section. Only two were seen. Cohuilla Valley April 8th, and near San Gorgonia May 29th. The latter, a + , was laying.

46. Contopus richardsonit (Swains.). (Western Wood Pervee). One taken in Cohuilla Valley April 7th, and two at Bear Valley. They are not uncommon in the mountains.

47. Empidonax difficilis Baird. (Baird's Flycatcher). Four were taken in Cohuilla Valley and one at San Bernardino. This species frequents the thicker parts of the timber in the river bottoms at Yuma where they are quite abundant. They were repeatedly shot for E. obscurus and E. hammundi. Only one was taken in Bear Valley.

4S. Empidonax hammondi (Xantus). (Hammond's Flycatcher). One was taken April 14th, in Cohuilla Valley. A few were noted at Yuma although they were comparatively rare. A of was shot June 26th in Bear Valley. She had incubated and would have laid again shortly.

49. Empidonax obscurus (Swains.). (Wright's Flycatcher). This is a very rare bird in the Cohuilla Valley where I have taken but one; that April Sth. Another was taken at Banning, April 21st. At I uma they were also comparatively rare, while none were observed at the other places visited.

5o. Pyrocepilalus rubineus mexicanus (Scl.). (Vermillion Fly-catcher). This species was found only at Yuma where they were not nearly so common as I had expected to find them. Young were taken as early as May 6th.

5I. Otocoris alpestris rubea Hensh. (Ruddy Horned Lark). None seen in Cohuilla Valley or at Yuma. They were common on the plain between Banning and San Gorgonio. I have often found them abundant around Riverside (especially in winter), where they breed in the vineyards, orchards, etc. They are very seldom seen about San Bernardino where the ground is probably too damp to suit them.

A small flock was seen along the marshy bosder of the lake in Bear Valley June 8th.

52. Cyanocitta stelleri frontalis (Ridgw.). (Bluefronted $\mathcal{F}_{\text {ay }}$. Abundant in the lower pine regions, but rare in Bear Valley. Probably because it is above the oak region where their food is found. 
53. Aphelocoma californica (Vig.). (California fay). Not common in San Bernardino Valley. They seldom occur below 2000 feet altitude. A pair were seen June igth, north of Bear Valley, they were on the top of a high ridge of mountains at an altitude of about 8 ooo feet. I have never before seen them above the lower edge of the pine belt, say at an altitude of 5ooo feet.

54. Picicorvus columbianus (Wils.). (Clarke's Nutcracker). Four were taken in Bear Valley in June. They are not uncommon, being found only at high altitudes.

55. Cyanocephalus cyanocephalus (Wied). (Pinon Fay). Not uncommon in Bear Valley. Several young were taken in June. Stomachs contained beetles and other insects. Not seen elsewhere.

56. Molothrus ater obscurus (Gmel.). (Dwarf Cowbird.) Common at Yuma.

57. Xanthocephalus xanthocephatus (Bonap.). ( rellow-headed Blackbird). This species is nearly always to be found near some of the marshy places in the San Mateo Canon. They are of irregular occurrence in the San Bernardino Valley, although some are always to be found in some part of it.

Took nests in Bear Valley in June. They were placed a few feet above the water in bulrushes, marsh grass, etc. Eggs usually four.

58. Agelaius pheniceus (Linn.). (Red-winged Blackbird). One was taken in Cohuilla Valley April 16 th. They are not uncommon in the San Bernardino Valley, where they breed.

59. Agelaius gubernator (Wagl.). (Bicolored Blackbird). This bird should occur here if anywhere. I have never seen it and do not believe in the variety.*

6o. Agellaius tricolor (Nutt.). (Tricolored Blackbird). One was obtained at San Gorgonio May 26th. They are more common in winter.

6I. Sturnella magna neglecta (Aud.). (Western Meadowlark). Probably only a migrant in Cohuilla Valley and at Yuma. Common around San Bernardino and not uncommon in Bear Valley.

62. ICterus Parisorum Bonap. (Scott's Oriole). One was heard April 6th. in Chino canon, Cohuilla Valley. Rare; this i

* We have seen undoubted specimens of var. gubernator which were collected in the San Bernardino Valley. Furthermore, we do not see how $\mathbf{M r}$, Stephens can admit tricolor and consistently reject gubernator. $-\mathrm{Ed}$, 
the only one noted. I had expected to find some few breeding in the Valley as I have seen old nests there.

63. Icterus cucullatus Swains. (Hooded Oriole). Rare: only two obtained. April 2 Ist. at Banning and May 13th. at Yuma.

64. Icterus bullock1 (Swains.). (Bullock's Oriole). Common. Was seen at all places. Breeds commonly north of the Colorado Desert.

65. Scolecophagus cyanocephalus (Wagl.). (Brewer's Blackbird). Common everywhere near water and ir fields.

66. Carpodacus purpureus californicus Baird. (California Purple Finch). Three were taken in Cohuilla Valley. They are a rare Winter resident this far south.

67. Carpodacus frontalis (Say). (House Finch). A nest of this bird was found in Cohuilla Valley April 5th. It contained three young. The stomach of one which was shot contained small, half formed seeds. A male taken in Bear Valley June IIth. was in full song, but the song seemed different from anything I had previously heard. It is a common bird with us.*

68. Spinus tristes (Linn.). (American Goldfinch). A pair was taken at San Bernardino May $\mathrm{I} 7$ th.

69. Spinus psaltria (Say). (Arkansas Goldfinch). Common in the Cohuilla Valley. They are gregarious, but the flocks are small.

70. Spinus lawrencei (Cass.). (Lazurence's Goldfinch). Not common in any locality visited. Noted from Cohuilla Valley April 12 th. and 15 th. and Bear Valley June 22 nd.

71. Sprnus pinus (Wils.). (Pine Siskin). A pair was taken April I 2th. in Cohuilla Valley.

72. Ammodramus sandwichensis alaudinus (Bonap.). (Western Savanna Sparrow). Only two of this species were noted. One, a 5 , in Cohuilla Valley April 3rd. The other a of hetween Banning and San Gorgonio April 23rd. This last was moulting.

73. Chondestes gramacus strigatus (Swains.). (Western Lark Sparrow) Common resident. Breeds.

74. Zonotrichia gambeli (Nutt.). (Gambel's Sparrow). This species was not found common anywhere, only five specimens

* I have here included var. rhodocolpus, which Mr. Ridgway informs me has been decided to be only individual variation.-Ed. 
having been taken. Four in Cohuilla Valley and one at Banning. They are abundant Winter residents.

75. Spizeli,a socialis arizone Coues. (Western Chipping Sparrow). A ô shot in Cohuilla Valley April Ist answers Dr. Coue's description of this variety, but I doubt if the variety is tenable. Specimens from nearer the coast show all gradations of the crown patch. One was taken at Banning and another at Yuma. They seem to be uncommon in these localities while I found thern rather common at Bear Valley in the open parts of the pine timber. A young male was taken here June IIth, which proves that they breed in this locality.

76. Spizella breweri Cass. (Brewer's Sparrow). This was a common bird in all the localities visited except Yuma, where it probably occurs in Winter as well as during the migrations. They evidently breed in Bear Valley.

77. Spizella atrigularis (Cab.). (Black-chinned Sparrow). This is not a common bird in the Cohuilla Valley, at least at this time of the year. They were found at all the localities visited with the exception of Yuma, where they probably occur as migrants. A of shot April zoth at San Bernardino was laying, had probably dropped one egg as the ovary contained three well developed ova. They were rather common in the lower part of Cajon Pass.

78. Junco hyemalis oregonus (Towns.). (Oregon funco). Not uncommon in Bear Valley where they breed.

79. Амphispiza bilineata (Cass.). (Black-throated Sparrow.) Appears to be common in Cohuilla Valley where several were taken between April 5th and 15th. A pair of the birds, together with a nest containing young, was seen on the Mojave River June $5^{\text {th. }}$

8o. Amphispiza belli (Cass.). (Bell's Sparrow). Not uncommon in the Mojave Desert. One was taken in Cajon Pass June $4^{\text {th }}$ and two were observed in Bear Valley.

81. Melospiza fasciata Fallax (Baird). (Desert Song Sparrow). Observed only at Yuma which is the only locality visited in which it is found.

82. Melospiza fasciata heermanni (Baird.). Hecrmann's Song 'Sparrow). This species is not uncommon in Cohuilla Valley and near San Bernardino. At Yuma they are replaced by variety fallax.

A $q$ taken in Cohuilla Valley April $7^{\text {th }}$ had already raised a 
brood, while another taken at San Bernardino on the $27^{\text {th }}$ was still incubating.

83. Melospiza lincolni (Aud.). (Lincoln's Sparrow). Three were obtained in the Cohuilla Valley. No others were noted.

84. Passerella iltaca megarhyncha (Baird). (Thickbilled Sparrow). Found only in Bear Valley. They were not common. Young were taken June I2th.

85. Pipilo maculatus megalonyx (Baird). (Spurred Towhee). One was obtained May 25th near San Gorgonio and another in Bear Valley June I2th.

86. Pipilo chlorurus (Towns.). (Green-tailed Towhee). Was not uncommon in Bear Valley in June.

87. Pipilo fuscus crissalis (Vig.). (Californian Towhee). Common in many localities.

88. Pipilo Alberti Baird. (Albert's Towhee). This species was found only at Yuma where it was common. As a usual thing it keeps strictly to the bottom lands. Its habits are much like those of the other brown Pipilos, none of which are such vigorous scratchers in the leaves as the black Pipilos. Alberti is least of all addicted to this habit.

Its calls and song are pitched on a higher key than any of the others and might be called squeaky.

None of the others of the family were found at Yuma, although $P$. chlorurus is most probably found as a migrant and $P$. fuscus mesoleucus may occur in suitable localities, such as the bases of low mountains and in the broken ground away from the river.

S9. Habia melanocephala (Swains.). (Black-headed Grosbeak). But three noted, one at Yuma and a pair in Bear Valley. They breed abundantly in the mountains.

9o. Guiraca cæerulea (Linn.). (Blue Grosbeak). Not common in the San Bernardino Valley. At Yuma they were found moderately abundant.

9i. Passerina amena (Say). (Lazuli Bunting). Common in San Bernardino and Bear Valleys.

92. Piranga ludoviciana (Wils.). (Louisiana Tanager). One shot at San Bernardino, another at Yuma, and another at San Gorgonio.

93. Piranga rubra cooperi Ridgw. (Cooper's Tanager). Three were seen at Yuma. I have never seen them further west. 94. Petrochelidon Lunifrons (Say). (Cliff Swallow). 
A colony of these birds built their nests under the juncture of the larger branches with the trunks of the large pines in Bear Valley, no suitable cliffs being near the water.

95. Tachycineta thalassina (Swains.). (Violet-Green Swallow). Abundant everywhere during the migrations. Three observed in Bear Valley in June.

96. Phainopepla nitens (Swains.). (Phainopepla). This does not seem to be a common bird in Cohuilla Valley, only one being noted; a 3 , April 6th. A single bird was also observed in a patch of cacti near San Bernardino, April 29th, and one near San Gorgonio, May 25th.

At Yuma they are not uncommon, several being taken, among which were two young. They are very irregular in their appearance on the west side of the mountains.

97. Lanius ludovicianus excubitorides (Swains.). (White-rumped Shrike). Common.

98. Vireo Gilvus (Vieill.). (Warbling Vireo). A $\hat{o}$ was obtained on April rst in the Cohuilla Valley, where they are only migrants. One was also taken May $4^{\text {th }}$ at Yuma.

99. Vireo solitarius cassinil (Xantus). . (Cassin's Vireo). This species is not uncommon in the Cohuilla Valley, where several were taken between the $3^{\mathrm{rd}}$ and I $3^{\text {th }}$ of April.

At Yuma it is probably only a migrant, although a $\hat{\delta}$ was taken May 8th. One was also obtained in Bear Valley June gth, where they probably breed in limited numbers.

ioo. Vireo bellit pusillus (Coues). (Least Vireo). This species was not common in any of the localities risited. Two were noted in Cohuilla Valley; one at San Bernardino, and a few at Yuma. I was fortunate enough to discover a nest at the latter place May I2th. It was placed in a small bush in a thicket, was about three feet from the ground, and contained three eggs, besides one of Molothrus ater obscurus, in which incubation had commenced.

ior. Vireo vicinior Coues. (Gray Vireo). This species was met with only in Cajon Pass, where they were not uncommen, six being taken June $4^{\text {th. and }} 5$ th. and another July ist. Several more were also heard.

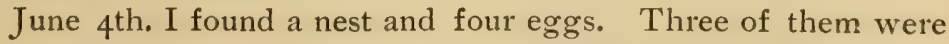
very nearly fresh, the other had been incubated four or five days.

The nest was built in the chaparral which thickly covers the whole region, and was about four feet from the ground. It was very lightly attached except on one side, but the bush in which it 
was built was so stiff and matted together that it could have moved but little, even in a strong wind.

It is a rare bird in Southern California so far as my experience goes and from its inhabiting such thick brush is very hard to get at.

102. Helminthophila ruficapilla gutturalis Ridgw. (Calaveras Warbler). This is a very rare species with us, I have only taken one specimen prior to this year when I was fortunate enough to obtain three males in the Cohuilla Valley on April 9th., I 2 th., and I 4 th., respectively. It seems strange to me that this species is wanting in the interior.

103. Helminthophila celata lutescens (Ridgw.). (Lutescent Warbler). This species is not uncommon in the Cohuilla Valley during the migrations. Five specimens were taken between April Ist. and I 2 th. I have no record of its occurrence at Yuma. A young $\&$ was taken in Bear Valley June $25^{\text {th }}$.

10+* (Yellow Warbler). Common every where.

105. Dendroica Auduboni (Towns.). (Audubon's Warbler). Quite abundant in the Cohuilla Valley where they are Winter residents in small numbers. Not uncommon at Bear Valley. A 9 taken at the latter place June I 9 th. had a feather in her mouth, and, as she was hopping about the ground, I suppose she was in search of other materials for a nest. Her abdomen contained a mass of tape-worms that would equal one of her eggs in bulk. A few breed in the high mountains. They are common Winter residents in the coast region.

io6. Dendroica nigrescens (Towns.). (Black Throated Gray Warbler). Probably only a migrant in the Colorado Desert. They breed not uncommonly in Bear Valley where several, both adults and young were taken in June.

i07. Dendroica townsendi (Nutt.). (Townsend's Warbler). Rare. Only three were seen. These were taken at Yuma May I. 3 th. They were excessively fat. The species is a rare migrant in Southern California.

ioS. Geotillypis macgillivrayi (Aud.). (Macgillivray's Warbler). Not uncommon in Cohuilla Valley and at Yuma. None were noted elsewhere although they occur at San Bernardino and probably in Bear Valley.

109. Geothlypis trichas occidentalis Brewst. (Western iellowthroat) This species is not common in Cohuilla Valley; three specimens were taken here and one at Banning. 
110. ICteria virens longicauda (Lawr.). (Long-tailed Chat). Two ô were taken at Yuma. They are occasional at San Bernardino.

ii i. Sylvania pusilla pileolata (Pall.). (Pileolated Warbler). But six of this species are noted. Four from Cohuilla Valley, one from Banning, and one from Yuma.

ir2. Anthus pensilvanicus (Lath.). (American Pipit). One taken in Cohuilla Valley April 9th. was moulting. They are rather common Winter residents in Southern California.

II3. Oroscoptes montanus (Towns.). (Sage Thrasher). A young $\delta$ was shot at Rabbit Springs June 6th. It was most probably raised in the inmediate vicinity. Several more were seen but they were too shy to admit of an approach within gunshot.

I14. Mimus polyglottos (Linn.). (Mockingbird). A common resident.

I15. Harporhynchus Redivivus (Gamb.). (Californian Thrasher). Common in the San Bernardino Valley. A $q$ shot May ist was incubating.

ii6. Harporhynchus Lecontei (Lawr.). (Leconte's Thrasher). On April roth a young o was taken from a nest in Cohuilla Valley. The brood consisted of four but the others were left a few days

A nest containing four eggs was also found on the same day, It was built in a cholla cactus about $2 \mathrm{~T} / 2$ feet from the ground. It was an old nest which had been relined and was so rotten as to fall to pieces while I was trying to get it out of the cactus. The eggs contained feathered embyros. The of flew from the nest on my approach I tried fully half an hour to get a shot at her but had to give it up as she finally got so wild that she hid.

Today I must have driven ten miles through country well suited to the wants of this species and where they should be found, if they are in the country with the above results. I also found several old nests, some of which must have been made many years, ago.

I have seen but one nest built in anything but a cholla cactus (Opuntia), this was placed in a "turpentine tree," a peculiar, almost leafless shrub with dense, thorny branches.

To find the nest of this bird one needs to drive about in the sage bush, greasewood, and other chaparrel, where it grows sparsely and has a cholla interspersed here and there. A glance at each 
cholla will usually suffice, as the nest is large and conspicuous. At times, if the cholla is more bushy than usual, a closer inspection is necessary. The parents sit closely, so that one can approach within a few yards before they slip off-which they usually do on the opposite side-and, dropping to the ground, run away, taking care to keep behind brush, etc., so that one may not see them at all. When they fly it is usually only high enough to clear the brush. In running they carry the long tail elevated more or less above the horizontal.

On April I Ith a $q$ was seen to fly from a nest in a cholla. This nest was about two feet from the ground and contained four eggs in which incubation was advanced.

On the 16 th I again visited the nest from which I took the young $q$ on the Ioth. One of the remaining three was out of the nest, though only a few yards distant. The others would probably have left to-morrow. When I first saw this nest, March 3 oth, the young were about three days old, which shows that the young of this species must leave the nest when about twenty days old.

On the 17 th I found a nest and two eggs. It was left for the full set, which consisted of only three in this instance. The nest was placed in a cholla about three feet from the ground.

The bird is not very rare in suitable places. I found them also in San Gorgonio Pass on May 27th, and in a scattering growth of yuccas on the Mojave Desert near the river of the same name. None were noted at Yuma.

ii7. Harporhynchus crissalis (Henry). (Crissal Thrasher). Noted at Yuma only. They are not common, only a few being seen. They are also very wild and hard to approach.

i 8. Campylorhy nchus brunneicapillus (Lafr.). (Cactus Wren). Common, breeding in all the localities visited excepting Bear Valley, where none were seen. All the nests found were placed in tuni or cholla cacti.

119. Salpinctes obsoletus (Say). (Rock Wren). Only three were noted: Cohuilla Valley, Yuma, and Bear Valley. It is a common Winter resident in some localities.

I20. Catherpes mexicanus conspersus Ridgw. (Canon Wren). I regard this as a rare bird with us. The only one noted this Spring was heard in the cliffs in Cohuilla Valley April I4th, I was, however, unable to get a glimpse of it.

It only sang at tantalizingly long intervals, changing its position after every cessation. 
I2I. Thryothorus BeWICKII SPIIURUS (Vig.). (Vigor's Wren). But one noted. A young, near San Gorgonio, May 25th.

122. Troglodyes ä̈don parkmanil (Aud). Parkman's Wren). Common: the House Wren of this section. I have no record of its occurrence at Yuma in Summer.

123. Cistothorus Palustris (Wils.). (Long-billed Marsh Wren). Not common in the Cohuilla Valley although may be found about the water. Generally distributed in marshy localities.

124. Certhia familiaris americana (Bonap.). (Brown Creeper). Only one noted. A \&, Bear Valley, June Ioth.

125. Sitta Carolinensis aculeata (Cass.). (Slender-billed Nuthatch). Found only in the pine region.

I26. Sitta pygmea Vig. (Pygmy Nuthatch). Not common. Found only in Bear Valley, where five were taken.

127. Parus inornatus Gamb. (Plain Titmouse). This is a very rare species here. I have not seen one before in several years. Two were shot in the chaparral near San Gorgonio and two in Cajon Pass.

128. Parus gambeli Ridgw. (Mountain Chickadee). Several were seen near San Gorgonio May 29th. They were probably breeding. Not uncommon in Bear Valley.

June roth I saw a $\delta$ of this species go to a pine stub and fly away again, I enlarged the opening and was surprised to find the o on the nest. I caught her in my hand. The nest was placed in what was originally a "weather chick" in the wood, which had rotted away some, the pieces being in all probability carried out by the birds. It contained seven eggs far advanced in incubation,

129. Psaltriparus minimus californicus Ridgw. (Californian Bush-tit). Common in San Bernardino and Bear Valleys where they breed. Young were taken as early as May Igth.

i3o. Auriparus flaviceps (Sund.). (Verdin). A young $q$ was taken from the nest (from which another flew on my approach) in Cohuilla Valley, April 2d. Another, together with the adult $q$, was also taken the same day and in the same locality. They were probably the parent and another young of the same brood. The adult bird would have laid again on the morrow.

At Cohuilla Valley this species was more common than $I$ had expected to find them. Their nests are comparatively easy to find, being very bulky for so small a bird. They are usually found near the einds of the branches of some thorny tree or shrub, commonly the mesquite in this locality, which grows low, often sprawling 
along the ground in masses 30 or 40 feet in diameter and perhaps 12 or 15 feet high. In this case it forms an impenetrable, thorny mass well suited for a nesting site for this and other species. The mesquite is not plenty here, occurring only where the soil is fairly good. There is one grove of two or three acres where they grow more tree-like. This is a favorite resort for A. flaviceps.

On the $9^{\text {th }}$ of April a + was taken from a nest containing four eggs. The nest was about six feet above the ground among the branches of a mesquite. Incubation was so far advanced that one egg popped open in blowing.

At Yuma the birds were not common. Seven adults and one young were taken. I also found two nests, one old one, and the other already deserted by the young. None were seen elsewhere.

The song is short end clear, but not often heard, the usual note being "tsup," which is uttered quite loudly for so small a bird. This note is uttered repeatedly, though at times they will remain silent for several minutes when they will commence again from a different position. They are very restless little fellows, and one needs to be active to get them. They are not gregarious like other titmice.

131. Regulus calendula (Linn.). (Ruby-crowned Kinglet). A regular Winter visitor in Southern California.

i 32. Polioptila carulea (Linn.). (Blue-GrayGnatcatcher. Not very common in the San Bernardino Valley, where they breed small numbers. Was not seen at Yuma where variety plumbea takes its place. I think, however, that it is a Winter resident there.

133. Polioptila plumbea Baird. (Plumbeous Gnatcatcher). This bird was met with only at Yuma, where it was rather common. I have seen several families besides finding two sets of eggs. The usual number to a brood is four, but I think that in one instance I saw five. It is found in the thick mesquite timber, in the willows, and in the sage brush at the edge of the hills. In fact they seem to care little what the timber is so long as there is plenty of it. They are very restless and their calls are very weak, especially when compared with carulea.

The black caps of the males of plumbea and Californica are worn but little more than half the year, i. e.-in the breeding season. From about September to February the males, like the females, being gray-crowned, but probably, in some cases, showing traces of the black cap. As far as I can remember the black markings of the forehead, etc., of ccerulea are persistent. 


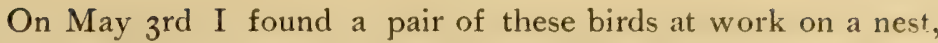
the next day it was completed outwardly, although I did not climb to see if it was lined. On the Sth I saw the head and tail of the bird on the nest. I whistled and it came off and stood on a branch a few inches distant. I plainly saw his black cap as he stepped back into the nest a moment later, and supposing that he was incubating on the full set I shot him. On climbing to the nest I found but two eggs and left them for further developments. On the IIth I found the female on the nest, she sat so closely that I nearly caught her in my hands. The nest now contained four eggs, in which incubation had just commenced. It was built in a mesquite, $\mathrm{I} 2$ feet from the ground, and was overhung by a branch of mistletoe.

On the 14th I found another nest built in a bunch of dead mistletoe Io feet from the ground. I had to drive the $f$ off the nest three times before he would go far enough for it to be safe for me to shoot him, even then I had to shake the end of a drooping branch to get him off at all. Nest contained four eggs, and one of Molothrus ater obscurus.

134. Polioptilla californica Brewst. (Black-tailed Gnatcatcher). Only one noted. San Bernardino, April 28th.

135. Turdus ustulatus (Nutt.). (Russet-backed Thrush). One seen in Cohuilla Valley and three at Yuma. They breed in the San Bernardino Valley.

I36. Turdus aonat.aschk a Aunboni (Baird). (Audubon's Hermit Thrush). A o obtained in Cohuilla Valley, April I 5 th, was the only one seen. They were heard in Bear Valley.

I37. Merula migratoria propingua Ridgw. (Western Robin). Two were seen in Cohuilla Valley, and a few in Bear Valley. The species is an irregular Winter visitant in the valleys of Southern California, some Winters not appearing at all and again coming in multitudes. A few breed regularly in the pine regions.

i38. Sialia mexicana Swains. (Western Bluebird). Probably only a migrant in Cohuilla Valley and at Yuma. At Bear Valley they are common and breed. The nests are generally built in holes in stumps.

139. Sialia ARctica (Swains.). (Mountain Bluebird). Found only in Bear Valley where they are not common. Young were seen June igth. 


\title{
AMMODRAMUS BELDINGI RIDGW. (BELDING'S MARSH SPARROW).*
}

\author{
BY B. T. GAULT.
}

While at National City, San Diego County, California, during the Spring of $188_{3}$, my attention was directed to the salt marshes of that locality as being the place to look for something rare in the line of bird life.

A trip was accordingly made to the marshes May 24th, with the following success: I found $A$. belding $i$ to be very abundant in certain spots, as many as five or six being seen from one stand in the space of as many minutes.

At first I was struck with the similarity of action to that of the Yellow-winged Sparrow [Ammodramus savannarum passerinus], more particularly in their manner of flight, as they skimmed over the marsh, but a few feet above its surface, in short, irregular flights. Being unconscious of the fact that I was among rare birds, as it seems they have turned out to be, I regret very much that I did not give them the study I should, had I known positively what they were.

Nevertheless, after going over the marsh carefully, for the purpose of securing specimens of the California Clapper Rail [Rallus obsoletus], I turned my steps towards the sparrows.

Three specimens were shot, the second, a female, was flushed from a nest of eggs and afterwards shot. She was very shy in her movements, and proved to be very difficult to approach; this was augmented by the treacherous condition of the tide-water ditches which intersect the marshes in all directions, the larger branches being too wide to jump and too muddy to wade; however, the bird was finally brought to bag. Had my eyes not been turned in the direction of the nest, I should certainly have overlooked it, for I could not have been nearer than seventy or eighty feet when the bird flew, but with a peculiarity that immediately attracted my attention.

She at first shot off quietly a few inches above the marsh, then settled down not twenty-five feet away; then upon again, short-

*This was originally described as Passerculus anthinus, but is, I think, referable to this species -ED. 
ening the flight this time to half that distance, repeating the maneuver a number of times. On going to the place whence the bird first started up I was not surprised to find the nest.

That evening a specimen of the bird was shown to a gentleman by the name of Plimpton, residing at National City, who is very well posted on birds generally. He was of the opinion that they were the Western Savanna Sparrow (Ammodramus sandwichensis alaudinus), but pronounced the nest a good find. I entered them in my field book by that name, and should probably have been satisfied to call them as such had not my friend Mr. H. K. Coale, of Chicago, pointed out the dissimilarity existing between them and certain specimens of Ammodramus sandwichensis alaudinus in his cabinet. A skin was afterwards forwarded by Mr. Coale to Mr. Robert Ridgway, of the National Museum, Washington, D. C., for identification. It was returned bearing the name Passerculus anthinus, which fact ought to set at rest all doubts regarding identity. To an inquiry by Mr. Coale, about the bird's breeding habits, he replies:

"That as far as he knows the $P$. anthinus nest and eggs have never been recorded, and birds are very rare." Hence these notes at the request of $\mathrm{Mr}$. Coale.

The specimens, Nos. 249, 250 and $25^{2}$ (author's collection), consist of two males and one female. No appreciable difference exists between the sexes, except that the males may be a trifle the largest. A general description is as follows:

The back, including crown, is of an ashy-brown color; the ash predominating on the cervix, shading to a darker and slightly yellowish-brown on the rump. This is streaked with a darker brown, the streaks being broadest and thickest in the interscapular region. A yellowish superciliary stripe passes from the nostrils over the eye to a point a little beyond; there is a faint yellowish suffusion around the auriculars and chin, and faint traces of yellow in the coronal median stripe. Below, the ground color is of a dirty brownish-white, the color being most nearly pure on the abdomen and crissum. Breast, sides of neck, and malar region, marked with sagittate marks of dark-brown; thickest on the breast, where they form into lines. Flanks, sides of body, and under tail coverts, striped with dark brown; stripes broadest on the flanks. Primaries, secondaries, tertiaries and tail feathers are of a light brown, their edges being bordered with a brownish-ash color, presenting a bleached look, most noticeable on the tertiaries and rectrices; these 
have a worn appearance. Feet, flesh color. The bill, which is of an acuminate shape, horn color, darkest on the culmen; this is a little longer than the lower mandible, and slightly hooked at the end.

Their average measurements are: Length, 5.I 8 inches; wing, 2.62 inches; tail, 2.18 inches; tarsus, .69 inches; culmen, .44 inches.

The nest, containing three fresh eggs, was situated in a patch of marsh weed, apparently raised a little above the surrounding ground. Although several feet above tide-water mark, it was completely saturated with water. If the female had not been seen to leave the nest, and had not the eggs been warm to the touch, I should certainly have thought that it was deserted. This is probably owing to the porous condition of the ground, and absorbing properties of the material used in the construction of the nest. But in this connection I will say that I have noticed the same in the nests of the Field Plover (Bartramia longicauda) and Black Tern (Hydrochelidon nigra surinamensis), and it has often been a matter of wonderment to me as to how the eggs could successfully incubate.

The composition of the nest consisted almost exclusively of weed stalks, with a little grass and a few feathers interwoven, the whole arranged in a rather careless manner, without regard to strength, which was not required in this case.

The eggs average seventy-seven one-hundredths of an inch in length, by fifty-eight one-hundredths of an inch in breadth. Their respective measurements being: $.76 \times .5^{8}$ inches, $.77 \times .59$ inches, and $.78 \times .5^{8}$ inches. The ground color is dirty white of a brownish tinge, caused by minute specks of brown and lavender.

Before the eggs were emptied of their contents there was a pinkish tinge to the shell resembling the color of the Wood Pewee's egg. This is marked with spots and specks of lavender and blotches of amber-brown, congregating principally toward the larger end, with an occasional streak of a darker brown shade. On the whole they may, with propriety, be classed handsome eggs. 


\title{
A CONTRIBUTION TO OUR KNOWLEDGE OF ALBINISM.
}

\author{
BY GEO. L. TOPPAN.
}

Albinism is a subject, althougn probably more of a physiological than an ornithological one, which, I think, will prove interesting to the majority of ornithologists as well as to the zoölogists generally. It is one of those little known phases of animal life which we have been content to let remain in a state of almost pristine obscurity. The ornithological literature on the subject may almost be described as nothing, what little we have being merely a few lists of those species of birds in which albinism has been known to to occur.

The object of the present paper is not only to give a mere list, but to give such physiological facts as I have been able to obtain. Further, it is not confined to ornithology alone, but will treat of the other divisions of the animal kingdom as well, especial attention being paid to the human race.

In this connection I take pleasure in acknowledging valuable aid received from Dr. Geo. Henry Fox, of New York, Mr. Robert Ridgway, of Washington, D. C., and several other gentlemen to whom due credit is given in the following pages.

The term "albino" was first used by the Portugese sailors, who applied it to the white negroes that they met with on the coast of Africa.

Albinism is a congenital absence of pigment. It is of two varieties; universal and partial.

Dr. Fox* says "an albino of the Caucasian race has a milkwhite but otherwise normal skin, a growth of white, fine silky hair upon the head, and an absence of pigment in the choroid coat of the eye, which gives the iris and pupil a red appearance, such as is often noticed in the white rabbit. In other respects the physical condition of an albino is normal, and the assertion that mental weakness is associated with a general loss of pigment fails to be verified in a large proportion of cases."

The subject is further treated in the American Cyclopadiat as

- Photographic Illustrations of Skin Diseases, by Geo. Henry Fox, M.D., Chap. v., p. 140.

† Vol. I, pp. $253 \& 254$. 
follows: "These persons, whether Indian, negro or white, appear of a uniformly dead, milky hue, with hair of the same shade, and eyes with the iris deficient in the black, or blue, or hazel pigment, which in others conceals the delicate network of blood-vessels; and the intense redness they diffuse over the surface. In the albino, both the pupil and iris lacking this colored curtain, the former, from the concentration within it of fine blood-vessels, is of a deep red, and the circle around it is of a pink color."

Speaking of the negroes of Africa, the same authority says: "With the features of the negro and the peculiarly woolly form of the hair, the jet black hue, which seems given to the inhabitants of the tropics to enable them to bear the intense glare of the sun, was like that of the white rabbit and ferret, and, like this, better suited for use in the moonlight and in places sheltered from the light of day. From this inability to bear the light, which, however, is said to be much exaggerated, Linnæus called the albinos 'nocturnal men.' They generally lack the strength of other men; and a peculiar harshness of the skin, such as is noticed in leprosy, would seem to indicate that the phenomenon might result from a diseased organization."

Another account* says "the skin is perfectly pigmentless and white, excepting where the blood-vessels coursing beneath it give it a rose tint. The general condition of the skin is normal otherwise than as regards the absence of pigment. The hair is white or flaxen (in one case reported it was red), of a fine texture, and peculiarly silky sheen. The eye partakes of the anomaly; the iris is colorless, so that its blood-vessels give it a red hue, excepting when viewed obliquely the interference of light-rays give it a blue color. As a result of a want of pigments in the iris, albinos suffer from photophobia and nystagmus, and are seen constantly blinking the eyelids and rolling the eyes involuntarily from side to side. They see best in the twilight.

"Albinos are usually of a weak constitution, and are apt to be intellectually deficient. Exceptions are known, however, to both of these conditions, and one of the best papers extant on albinism, so it is said, was written by a German albino named Sachs."

Still another authority $\nmid$ says "all coloring of the outer cover-

* Arthur Van Harlingen in Buck's Reference Handbook of the Medical Sciences, Vol. I, p. 101.

+ Baron Richard von König-Warthausen, in Journal fur Ornithologie, Cab. II, 1854, pp. 249-253. 
ing of birds, no less than of mammals and other animals, depends on the existence and nature of a coloring medium. In the absence of this, everywhere or only here and there, partly as a rule, partly as an exception, white appears. If the pigment, however, exists, but in consequence of various not fully explained influences, is, in its effects, weaker in some individuals than in normal cases, then pale varieties arise.

"In the eye, as is known, the outer and inner surface of the veinal membrane (Choroidea), as well as the inner one of the iris, is covered with the so-called pigmentum nigrum. Where this is not existing, in consequence of hereditary disease, the blood-vessels shine through and the iris and pupil of the eye appear red.

"In general it may only be conjectured that where the vital powers of the body are insufficiently developed and the functions of the blood weak, many parts are only supplied with little coloring matter, or even none at all. Against this, however, (that such symptoms must always be a sign of disease), speaks the fact that some animals wear such a raiment at certain seasons of the year, or periods of life, and that the white color is altogether very wide spread among hirds. Besides, it does not follow that the diseased condition of certain organs weakens the body in every way, and the procreative power of such albinos is surely of decisive importance in the treatment of the question; how extended the weakness really is. If an animal possesses procreative power the sickly conditions can have only a small effect on the whole organism and extend in our case only to the generation of pigment. Thus, the fact that the numerous white varieties of our poultry, although they may be somewhat weaker, propagate as normal animals, without a gradual degeneration being perceptible, is settled. On the other side there is no lack of instances in the free state of nature."

It will be noticed that while Dr. Fox and Dr. Van Harlingen agree in their statements that otherwise than as regards loss of pigment the skin is normal, the authority in the Cyclopadia contradicts this, and says it has a peculiar harshness and may result from a diseased organization. My opportunities for observing living or freshly killed albinos have been necessarily few and far between, but, so far as my experience goes, I would unhesitatingly coincide with the former gentleman.

Another point of dispute seems to lie in the statement by Dr. Fox, that the physical and mental conditions are normal. This is disputed by both Dr. Van Harlingen, who says that they are 
usually of a weak constitution and apt to be intellectually deficient, and by the authority of the American Cyclopadia who says they lack the strength of other men. However, it will be noticed that Dr. Van Harlingen admits that the best paper extant was written by a German albino, while Baron Richard von König-Warthausen does not commit himself to either side of the question. This, it seems to me, throws the weight of evidence in favor of the undisturbed physical and mental power theory.

Dr. Van Harlingen* says, "the only etiological element known or suspected in the production of albinism is heredity, and even this is wanting in the greater number of cases. It seems probable that the sisters in any given family are likely to be attacked rather than the brothers, if more than one individual is affected."

The etiology is not mentioned by Dr. Fox or the American Cyclopadia further than that they both agree that it is a congenital absence of pigment.

Baron Richard von König-Warthausen† records an instance which occurred during his residence at Ulm (i $842-1846)$, where, on a public promenade in that city, a pair of white domestic sparrows raised a brood of young for several years.

Another authoritył says: "Speaking again of albinos I would ike to say something yet about their propagation.

"It is successful in domestic conditions as I have occasionally convinced myself.

"It may be about ten years since, when I lived in the same house with a weaver, who, partly for profit, partly for amusement, spent his leisure hours in training several birds; experiments of pairing different varieties; and bastard raising. Though not always successful he often obtained young ones from such breeds, and I remember very well his joy over a young one, which he showed me one day, that was gotten by the pairing of a white Canary female with a male Thistle Finch. It became a beautiful white specimen with a reddish-yellow breast-plate, but it did not live long. The man is now also dead, and I regret it the more as he was just the man, with sufficient patience, to continue such experiments.

"My experiments were limited, not having any albinos of other varieties, to the Laughing Dove (C. risoria), which I paired

*Buck's Reference Handbook of the Medical Sciences, Vol. I., p. 101.

+ Journal fur Ornithologie, Cab. II. 1854, pp. 249-253.

$\ddagger$ Julius Finger. Naumannia, 1858, p. $15 \%$. 
among themselves as well as with regularly colored individuals, and I was always successful, although I never obtained spotted ones, always only one colored specimens, either entirely white or Isabella-color.

"The young ones of these breeds also propagated arnong themselves."

Another authority* says, "in the same family several children are sometimes born albinos. They are generally of the male sex. An instance is recorded of a Welsh family, in which every alternate child was an albino. It is stated by Esquirol that two albinos married and had two children which were not albinos, but of quite brown color. It is not understood to what ultimate cause the phenomenon is to be attributed."

I can recall but three cases of this kind among North American Birds. The first is recorded by my friend Mr. R. Deanet as follows: "Another interesting example is that of a young Robin (Merula migratoria), milk-white, still unable to leave the nest. This specimen was taken at Saybrook, Conn., by Mr. H. A. Purdie, who informs me that the parent birds were in normal dress."

The other two cases were reported to me by Mr. Robert Ridgway (in epist.), as follows: "Two instances have come to my knowledge however, of all (four) specimens of a brood of young Robins (Merula migratoria) being perfect albinos (pink eyes and all), the parents being in normal plumage. These two cases occurred in the same locality (Laurel, Md.), on consecutive years ( $\mathrm{I}_{5} \mathrm{~S}_{5}$ and $\mathrm{I} 886$ ), but whether the parents were in both cases the same pair I am not sure; but I believe they were not."

From a careful perusal of the foregoing it will be seen that heredity is by no means a necessary adjunct to albinism.

It will also be noticed that while Dr. Van Harlingen says that the females are most likely to be affected the authority of the Cyclopadia says they are generally of the male sex.

I have recently examined a large number of albinos and have a few records. Out of over two hundred specimens only eightyone had any record of the sex attached or at all obtainable. Of this number forty-four, or fifty-four and one-third (54 $1 / 3)$ per cent. were males and thirty-seven, or forty-five and two-thirds $\left(45^{2} / 3\right)$ per cent. were females. This shows the predominance of the sexes, in birds 
at least, to be in favor of the males by eight and two-thirds $(82 / 3)$ per cent. Of course this is hardly an extensive enough test to settle the question satisfactorily, and different persons might arrive at different results for this reason. I have observed that in taking land birds only, the males will average a trifle over fifty-seven (57) per cent., and the females a trifle over forty-two (42) per cent., while among the water birds the averages that $I$ have obtained are males thirty-eight $\left(3^{8}\right)$ per cent. and females sixty-two $(62)$ per cent.

Partial albinism is spoken of by Dr. Fox* as follows: "Partial albinism is frequently seen in this country among the Southern negroes, and some present the appearance of a piebald circus horse. The white spot, or spots remain through life without change of size or tint. The affection is rarely, if ever, met with in the white race." He further says $\nmid$ "it is said that albinism is not uncommon among the negroes of Equatorial Africa, but I imagine that these white negroes, to whom the Portugese sailors first applied the term albino, were cases of leucoderma in which white patches (not congenital) gradually spread until no pigmented skin was left."

Another authoritył speaking of partial albinism says, "their condition can probably be accounted for by some circumstances after birth which will account for the change in the color of the skin, such for instance, as the case given by the writer in the Oologist, in which the skin has been injured on the back of a Swift, and the next year the patch of white feathers indicated the situation of the injury. The same thing is familiar in the case of the horse whose back or shoulder is galled by the harness; white patches appear owing to the lowered vitality of the injured part." The article then goes on to give as a possible cause of partial albinism the fact that in four specimens taken by the writer (a Black Squirrel with a white tail and some white about the head, and partially white specimens of Merula migratoria, Agelaius phaniceus and Anas boschas) he has found tape-worms (Tonia solium). He also adds that "the above may have been merely coincidences; still it has been observed sufficiently often to make the fact suspicious as a cause of albinism."

In regard to the first point, although admitting that such cases sometimes occur, I do not think that they do so sufficiently often in birds to cut any figure whatever in the production of albinism, and furthermore, from a medical standpoint, such cases would come un-

*Photographic Illustrations of Skin Diseases, by Géo. Henry Fox, M.D. Chap. V, p. r 40. +In epist.

¥G. A. M'Callum. The Auk. Vol. II, 1885 , pp. 113 \& Ir4. 
der the head of leucoderma, which is an acquired disease, while albinism is a congenital abnormality.

In reference to the latter conjecture I would say that I am of the opinion that the finding of trenice in the intestines has no bearing whatsoever upon the question, although I am forced to admit that I at one time thought it had. However, I have dissected quite a number of albinos in the last few years, and I have found very few instances of any organic trouble or the presence of tape-worms. Further than this I have found in a number of instances, that tapeworms existed in birds of normal plumage, and as the latter cases greatly outnumber those in which the plumage was albinistic, I have become convinced that it was merely a coincidence and had no effect upon the outward condition.

I remember a case where in a perfectly white Cowbird (Molothrus ater) the sexual organs had been totally destroyed by a small white worm which was, when discovered, imbedded in the suprarenal capsule. Another case, which I dissected in the Spring of I886, was an albino Lesser Scaup Duck (Aythya affinis). In this instance I could at first find no traces of the sexual organs whatever, a careful search with a good glass being at last rewarded by my finding an ovary. This was very small, smaller even than you would be likely to find in the Mniotiltida in Winter. However, I do not consider that the albinistic state of the plumage was in any way brought about by this fact. I then regarded it, and do still, as merely a case of non-development. I have also found worms in the kidneys of birds of normal plumage, one, a White-throated Sparrow (Zonotrichia albicollis), which I shot last Spring, was in the same condition as the Cowbird spoken of above, and yet the plumage was perfectly normal. Other cases are those of the Willow Thrush (Turdus fuscescens salicicolus) and Oregon Junco (Funco hyemalis oregonus) which were shot in Chicago by $\mathrm{my}$ friend $\mathrm{Mr} . \mathrm{H} . \mathrm{K}$. Coale. Both of these birds had worms in the kidneys and the sexual organs had completely disappeared, but they were, nevertheless, in normal dress.

In short I regard albinism as merely a congenital abnormality having no physiological significance.

Dr. Fox* says "in polar regions an absence of pigment is the rule rather than the exception. This being the case it seems strange that in the human race albinism should occur with perhaps the greatest frequency in regions near the equator."

*Photographic Illustrations of Skin Diseases. By Geo. Henry Fox, M.D. Chap. V. p. 140 
Now, as far as an absence of pigment in polar regions is concerned I agree with him, but if, as seems probable, he regards arctic animals such as the Polar Bear (Thalassarctos maritimus) and Northern Hare (Lepus americanus) as albinos, I disagree most decidedly. In the case of the hare the fur is white only part of the year, as is well known, and, although the bear is always in white dress, still it has not red eyes or any of the other supposed albinistic characteristics, and is, in my opinion, merely a wise provision of of nature for their protection.

We have several white birds, notably the Snowy Heron (Ardea candidissima), but I have never heard them called albinos nor do I believe that they are.

If white is the normal dress, and we admit that albinism is a congenital abnormality, it is beyond my comprehension how anyone can claim that such animals are albinos. In other words, how can anything be both normal and abnormal?

I will here mention the different forms of albinism as given by Baron Richard von König-Warthausen.* "On closer observation we have to distinguish: (1), Real albinos with red eyes, Leucopathici: (2), Birds with pure white or almost unchanged eyes, $A l$ bidi: (3), Such birds in which only isolated spots indicate the former connections, Maculati: (4), Bright, gray, yellowish variations, which in comparison with the marked distribution of colors in the normal conditions sometimes show them complete, but faded, as if they had suffered from outer influences (Weather-beaten; decomposition of colors; lime-wash; etc.) Pallescentes.

"Individuals of the first-class are the rarest. The second has various transitions downwards, and the fourth contains many very interestingly marked and characteristic specimens."

One more point I wish to bring up, i. e., the susceptibility of the various colors to albinism. I have found during my investigations that some colors are much more likely to give way to albinism than others. Black seems to be the most susceptible, as is well illustrated by the large number of perfect albinos found among the Corvidce and Icterida. On the other hand, red and yellow seem to be the colors least susceptible and capable of holding out longest against albinistic influence. I will cite a few cases as proof of this assertion. There is in the collection of Mr. R. Deane, of Chicago, a perfect albino Flicker (Colaptes auratus), barring the red nuchal crescent and the yellow on the under surfaces of the wing and tail

* Journal fur Ornithologie, Cab. II, 1854, pp. 249-253. 
feathers. These colors are normal, and the result is one of the handsomest albinos it has ever been my fortune to see. This specimen is exactly duplicated by one which Mr. Robert Ridgway described to me. Another instance is the red shoulder-patch on the Red-winged Blackbird (Agelaius phaniceus). I do not remember ever having seen an albino of this species that did not show some traces of the red on the shoulder, generally it is quite pronounced. Still another example is that of the Redstart (Setophaga ruticilla) described by Mr. Deane* and now in his collection. "The black head and breast are mottled with white, the black dorsum is replaced by bright oranget with a few blackish feathers intermixed, while the belly and crissum are much more strongly marked with orange than in a typical specimen." The same authority records in the same article a specimen of Acanthis linaria, pure white with the exception of the crimson crown-patch. A specimen of Tyrannns tyrannus also retains the flame-colored crown-patch. Another example is a specimen of Sturnella magna neglecta in the collection of the Smithsonian Institution at Washington, D. C. It is a perfect albino barring the yellow on the breast, which in this case, is a bright lemon.

The most complete list of North American birds which have been found in albinistic plumage has been published by Mr. R. Deane, $\downarrow$ and records examples of $\mathrm{I} I 9$ species. To this list I can add thirty-five species, the following being as complete a list as I have been able to compile.

I. Urinator lumme(Gunn.). Red-throated Loon. A specmen is in the collection of R. Deane, of Chicago, Ill.

2. Fratercula arctica glacialis (Temm.). Largebilled Puffin.**

3. Cepphus grylle (Linn.). BlackGuillemot. $+\dagger$

4. Uria troile (Linn.). Murre.t†

5. Alle alle (Linn.). Dovekie. A pure white specimen is in the collection of the American Museum of Natural History at New York.

6. Stercorarius Parasiticus (Linn.). Parasitic faeger.**

7. Larus heermanni Cass. Heerman's Gull. 杖

*Bull. Nutt. Orn. Club, Vol, I, 1876, p. 21.

+Italics are my own.

$\ddagger$ Bull. Nutt. Orn. Club, Vol. I, IS76, pp. 20-24, Vol. IV, I879, pp, 27-30, and Vol. V, 1880, pp. 25-30.

**Deane, Bull. Nutt. Orn. Club, Vol. V, 1880, pp. 25-30.

t+Deane, Bull. Nutt. Orn. Cluh, Vol. I, 1876 , pp. $20-24$.

$\ddagger \ddagger$ Deane, Bull. Nutt. Orn. Club, Vol. IV, 1879, pp, a7-30. 
8. Ossifraga gigantea (Gm.). Giant Fulmar.*

9. Merganser Serrator (Linn.). Red-breasted Merganser. A pure white specimen has been collected near Niagara Falls. $\nmid$

10. Anas boschas Linn. Mallard. A specimen is in the collection of the American Field, at Chicago, Ill.

II. Anas obscura Gmel. Black Duck. A specimen is in the collection of the Smithsonian Institution at Washington, D. C.

12. Anas strepera Linn. Gadwall. A i which was collected at Warsaw, Ill., April I5th, 1886, is now in the collection of C. K. Worthen. $†$

13. Anas penelope Linn. Widgeon. A pure white specimen is in the collection of F. Lorquin, of San Francisco, Cala. $†$

14. Anas crecca Linn. European Teal.\$

15. Anas carolinensis Gmel. Green-winged Teal. A specimen is in the collection of the American Field at Chicago, Ill.

I6. Anas discors Linn. Blue-winged Teal.*

I7. Spatula clypeata (Linn.). Shoveller. A specimen is in the collection of the American Field at Chicago, Ill.

18. Dafila acuta (Linn.). Pintail. A specimen is in the collection of R. Deane, of Chicago, Ill.

19. Aythya Americana (Eyt.). Redhead. A specimen is in the collection of the Smithsonian Institution at Washington, D.C.

20. Aythya vallisneria (Wils.). Canvas-back. A specimen is in the collection of R. Deane, of Chicago, Ill.

2i. Aythy A Affinis (Eyt.). Lesser Scaup Duck. A specimen is in the collection of Geo. L. Toppan of Chicago, Ill.

22. Glaucionetta clangula americana(Bonap.). American Golden-Eye. A specimen is in the collection of the Smithsonian Institution at Washington, D. C.

23. Charitonetta albeola (Linn.) Bufle-head.*

24. Clangula hyemalis (Linn.). Old-squaw. A specimen is in the collection of the Smithsonian Institution at Washington, D. C.

25. Oidemia americana Sw. \& Rich. American Scoter.

26. Oidemia fusca (Linn.). Velvet Scoter.*

27. Oidemia perspicillata (Linn.). Surf Scoter. A specimen is in the collection of R. Deane, of Chicago, Ill. 
28. Erismatura rubida (Wils.). Ruddy Duck.*

29. Branta canadensis (Linn.). Canada Goose. A specimen is in the collection of F. Lorquin, of San Francisco, Cala.*

3o. Branta bernicla (Linn.). Brant. $\dagger$

3I. Dendrocygna fulva (Gmel.). Fulvous Tree-duck.

32. Botaurus lentiginosus (Montag.). American Bit. tern. $\ddagger$

33. Porzana carolina (Linn.). Sora. A specimen was described to me by Mr. Robert Ridgway as fullows: Primaries snow-white, the rest of the plumage being normal. Toes bright gamboge yellow, presenting a striking contrast to the olive of the tarsi. The toes did not shade gradually into yellow, but were separated by a sharply defined boundary-line.

34. Gallinula galeata (Licht.). Florida Gallinule. A specimen in the collection of R. Deane, of Chicago, Ill., was shot at English Lake, Ind.

35. Fulica americana Gmel. American Coot. A specimen is in the collection of the Smithsonian Institution at Washington, $\mathrm{D}$. C.

36. Scolopax Rusticola Linn. European Woodcock. $\$$

37. Philohela minor (Gmel.). American Woodcock. $\dagger$

$3^{8}$. Gallinago delicata (Ord). Wilson's Snipe. A specimen is in the collection of Geo. L. Toppan, of Chicago, Ill.

39. Tringa canutus Linn. Knot. $\$$

40. Tringa minutilla Vieill. Least Sandpiper. A specimen is in the collection of R. Deane, of Chicago, Ill.

4I. Ereunetes pusillus (Linn.). Semipalmated Sandpiper.

42. Calidris arenaria (Linn.). Sanderling. $\$$

43. Limosa hamastica (Linn.). Hudsonian Godwit.

44. Numenius longirostris Wils. Long-billed Curlew.\$

45. Numenius hudsonicus Lath. Hudsonian Curlezv.

46. Charadrius dominicus Müll. American Golden Plover. A specimen is in the collection of B. T. Gault, of Chicago, Ill.

47. Colinus virginianus (Linn.). Bob-zuhite. Several specimens are in the collection of G. F. Morcom, of Chicago, Ill. 48. Oreortyx pictus (Dougl.). Mountain Partridge. $\dagger$

*From the Note-book of $\mathbf{R}$. Deane.

tDeane, Bull. Nutt. Orn. Club, Vol. I, IS76, pp. 20-24.

†Deane, Bull. Nutt. Orn. Club, Vol. IV, 1879, pp. 27-30.

¿Deane, Bull. Nutt. Orn. Club, Vol. V, 1880, pp. 25-30. 
49. Callipepla canifornica (Shaw). Californian Partridge. A specimen is in the collection of $\mathrm{R}$. Deane, of Chicago, Ill.

5o. Callipepia gambeli (Nutt.). Gambel's Partridge.*

5I. Dendragapus canadensis (Linn.). Canada Grouse. A specimen is in the collection of R. Deane, of Chicago, Ill.

52. Bonasa umbellus (Linn.). Ruffed Grouse. A specimen is in the collection of G. F. Morcom, of Chicago, Ill.

53. Tympanuchus americanus (Reich.). Prairie Hen. A specimen is in the collection of G. F. Morcom, of Chicago, Ill.

54. Pediocates phasianellus columbianus(Ord). Columbian Sharp-tailed Grouse. *

55. Meleagris gallopavo Linn. Wild Turkey. *

56. Ectopistes migratorius (Linn.). Passenger Pigeon. $\nmid$

57. Cathartes aura (Linn.). Turkey Vulture.*

58. Buteo buteo (Linn.). European Buzzard. *

59. Buteo borealis (Gmel.). Red-tailed Hawk. A specimen is in the collection of the Smithsonian Institution at Washington, D. C.

6o. Aquila phrisä́tos (Linn.). Golden Eagle. *

6i. Syrnium nebulosum (Forst.). Barred Owl. $\nmid$

62. Coccyzus erythrophthalmus (Wils.). Black-billed Cuckoo. A specimen is in the collection of R. Deane, of Chicago, Ill.

63. Ceryle alcyon (Linn.). Belted Kingfisher. $\ddagger$

64. Dryobates villosus (Linn.). Hairy Woodpecker.*

65. Dryobates pubescens (Linn.). Downy Woodpecker. A specimen is in the collection of R. Deane, of Chicago, Ill.

66. Melanerpes erythrocephalus (Linn.). Red-headed Woodpecker. *

67. Melanerpes carolinus (Linn.). Red-bellied Woodpecker. A specimen is in the collection of the Smithsonian Institution at Washington, D. C.

68. Colaptes auratus (Linn.). Flicker. A specimen is in the collection of R. Deane, of Chicago, Ill.

69. Chetura pelagica (Linn.). Chimney Swift. $\downarrow$

70. Trochilus colubris Linn. Ruby-throated Hummingbird.*

*Deane, Bull. Nutt. Orn. Club, Vol. V, r85o, pp. 25-30.

+Deane, Bull. Nutt. Orn. Club, Vol. I, 1876, pp. 20-24.

$\ddagger$ Deane, Bull. Nutt. Orn. Club, Vol. IV, 1879, pp. 27.30 
7r. Trochilus anna (Less.). Anna's Hummingbird. *

72. Milvulus Forficatus (Gmel.). Scissor-tailed Fly. catcher. *

73. Tyrannus tyrannus (Linn.). Kingbird. $\dagger$

74. Sayornis nigricans (Swains.). Black Phabe. A specimen is in the collection of the Smithsonian Institution at Washington, D. C.

75. Contopus virens (Linn.). Wood Pewee. \$

76. Alauda arvensis Linn. Skylark. §

77. Otocoris alpestris praticola Hensh. Prairie Horned Lark. A specimen is in the collection of R. Deane, of Chicago, Ill.

7S. Otocoris alpestris Chrysolema (Wagl.). Mexican Horned Lark. A specimen is in the collection at Woodward's Gardens, San Francisco, Cala. \|

79. Cyanocrtta cristata (Linn.). Blue Fay. A specimen is in the collection of G. F. Morcom, of Chicago, Ill.

8o. Aphelocoma sieberit Arizon e Ridgw. Arizona Fay.**

Si. Corvus coraxinuatus (Wagl.). American Raven.*

82. Corvus americanus Aud. American Crow. A specmen is in the collection of the Smithsonian Institution at Washing ton, D. C.

83. Corvus ossifragus Wils. Fish Crow. A specimen is in the collection of the Smithsonian Institution at Washington, D. C.

84. Sturnus vulgaris Linn. Starling.\$

S5. Dolichonyx oryzivorus (Linn.). Bobolink. Specimens are in the coliection of the Smithsonian Institution at Washington, D. C.

86. Molothrus Ater (Bodd.). Cowbird. A specimen is in the collection of Geo. L. Toppan, of Chicago, Ill.

S7. Xanthocephalus xanthocephalus (Bonap.). Fllow-headed Blackbird. A specimen is in the collection of the Smithsonian Institution at Washington, D. C.

* Deane, Bull. Nutt. Orn. Club. Vol, V. 1880. pp. 25-30.

+ Deane, Bull. Nutt. Orn, Club. Vol. I. 1876. pp. 20-24.

¥ Deane, Bull. Nutt. Orn. Club. Vol. IV. 1879. pp. 27. -30.

§ Journal fur Ornichologie, Cab. II. I 554 . pp. 249-253.

1 From the Note-book of R. Deane.

**Allen, J. A. Auk. Vol, IV. เ\$S7. p. 2 I. 
88. Agelaius pheniceus (Linn.). Red-winged Black bird. Several specimens are in the collection of the Smithsonian Institution at Washington, D. C. One of these is a beautifully marked specimen. It is a full plumaged male, in normal dress with the exception of a good sized, rather shield-shaped spot on the throat and breast; this is of a light salmon-color.

89. Sturneli a magna (Linn.). Meadow Lark. A specmen is in the collection of the Smithsonian Institution at Washington, D. C.

90. Sturnella magna neglecta (Aud.). Western Meadow lark. A specimen is in the collection of the Smithsonian Institution at Washington, D. C.

91. Scolecophagus Carolinus (Müll.). Rusty Blackbird. Specimens are in the collection of R. Deane, of Chicago, Ill.

92. Scolecophagus cyanocephalus (Wagl.). Brewer's blackbird. Specimens are in the collection of R. Deane, of Chicago, Ill.

93. Quiscalus quiscula (Linn.). Purple Grackle.*

94. Quiscalus Major Vieill. Boat-tailed Grackle. A specimen is in the collection of the Smithsonian Institution at Washington, D. C.

95. Pinicola enucleator (Linn.). Pine Grosbeak. †

96. Carpodacus purpureus (Gmel.). Purple Finch. $\ddagger$

97. Leucosticte tephrocotis littoralis (Baird). Hep. burn's Leucosticte. $†$

98. Acanthis hornemannil (Holb.). Grecnland Redpoll. +

99. Acanthis linaria (Linn.). Redpoll. A specimen is in the collection of R. Deane, of Chicago, Ill.

IOo. Spinus Tristes (Linn.). American Goldfinch. $\ddagger$

ioi. Poocetes gramineus (Gmel.). Vesper Sparrow. $\dagger$

ioz. Ammodramus sandichensis savanna (Wils.). $S a$ vanna Sparrow. $\ddagger$

103. Ammodrames caudacutus (Gmel.). Sharp-tailed Finch. A specimen is in the collection of $\mathrm{R}$. Deane, of Chicago.

rof. Chondestes gramicus (Say). Lark Sparrow. A specimen is in the collection of the Smithsonian Institution at Washington, D. C.

* Deane, Bull. Nutt. Orn. Club. Vol, I. 1876. pp. 27-30.

+ Deane, Bull. Nutt. Orn. Club. Vol. V. 1880. pp. 26-30.

¥ Deane, Bull. Nutt. Orn. Club. Vol. IV. 1879. pp. 27-30. 
105. Zonotrichia coronata (Pall.). Golden-crowned Sparrow. A specimen is in the collection of the Smithsonian Institution at W ashington, D. C.

106. Zonotrichia Albicollis (Gmel.). White-throated Sparrow. A specimen is in the collection of the Smithsonian Institution at Washington, D. C.

107. Spizella monticola (Gmel.). Tree Sparrow. A specimen is in the collection of R. Deane of Chicago, Ill.

108. Spizella socialis (Wils.). Chipping Sparrow.*

109. Spizella pusilla (Wils.). Field Sparrow. A specimen is in the collection of the Smithsonian Institution at Washington, D. C.

i Io. Junco hyemalis (Linn.). Slate-colored funco. A specimen is in the collection of the Smithsonian Institution at Washington, D. C.

ili. Junco hyemalis oregonous (Towns.). Oregon Funco. A specimen is in the collection of the Smithsonian Institution at Washington, D. C.

il Melospiza fasciata (Gmel.). Song Sparrow. A specimen is in the collection of R. Deane, of Chicago, Ill.

I13. Melospiza fasciata fallax (Baird). Desert Song Sparrow. A specimen is in the collection of $\mathrm{R}$. Deane, of Chicago, Ill.

114. Melospiza georgiana (Lath.). Swamp Sparrow. $\nmid$

I15. Passerella iliaca (Merr.). Fox Sparrow.*

iI6. Passer montanus. European Tree Sparrow. $\downarrow$

iI7. Passer domesticus. European House Sparrow.*

iis. Pipilo erytirophthalmus (Linn.). Towhee. Specimens are in the collection of the Smithsonian Institution at Wash${ }_{1}$ ngton, D. C.

i 19. Pipilo fuscus mesoleucus (Baird). Canon Towhee.

120. Pipilo fuscus crissalis (Vig.). Californian Towhec. A specimen is in the collection of the Smithsonian Institution at Washington, D. C.

121. Habia ludoviciana (Linn.). Rose-breasted Grosbeak.

122. Passerina cyanea (Linn.). Indigo Bunting. $\neq$

123. Calamospiza melanocorys Stejn. Lark Bunting.+

* Deane, Bull, Nutt."Orn. Club. Vol. I. 1876, pp. 20-24.

+Deane, Bull. Nutt. Orn. Club. Vol. IV. 1879, pp. 27-30.

¥Deane, Bull. Nutt. Orn. Club. Vol, V. 1880, pp. 26-30. 
124. Piranga erythromelas Vieill. Scarlet Tanager. A specimen is in the collection of R. Deane, of Chicago, Ill.

125. Progne subis (Linn.). Purple Martin.*

126. Petrochelidon Lunifrons (Say). Cliff Swallow. A specimen is in the collection of the American Museum of Natural History at New York.

127. Chelidon erythrogaster (Bodd.). Barn Swallow. A specimen is in the collection of R. Deane, of Chicago, Ill.

128. Tachycineta Bicolor (Vieill.). Tree Swallow. A specimen is in the collection of $\mathrm{R}$. Deane, of Chicago, Ill.

i29. Clivicola riparia (Linn.). Bank Swallow. A specimen is in the collection of the American Museum of Natural History at New York.

I30. Ampelis garrulus Linn. Bohemian Waxwing. $\nmid$

131. Ampelis cedrorum (Vieill.). Cedar Waxwing.*

132. Compsothlypis americana (Linn.). Parula Warbler. The collection of the Smithsonian Institution contains a very handsomely marked specimen of this species. The breast and under parts, excepting the yellow of the throat, reddish collar and side marks, is pure white. Top of head snow-white; the rest of the upper parts being beautifully mottled with white.

I33. Dendroica coronata (Linn.). Myrtle Warbier.*

I34. Dendroica auduboni (Towns.). Audubon's Warbler. A specimen is in the collection of $\mathrm{R}$. Deane, of Chicago, Ill.

135. Dendroica castanea (Wils.). Bay-breasted Warbler.*

I36. Dendroica striata (Forst.). Black-poll Warbler. A specimen is in the collection of the Acadcmy of Natural Sciences at Philadelphia, Pa.t

I37. Dendroica virens (Gmel.). Black-throated Green Warbler. A specimen is in the collection of G. A. Boardman, of Calais, Me.t.

i3S. Setophaga Ruticilla (Linn.). American Redstart. A specimen is in the collection of $\mathrm{R}$. Deane, of Chicago, Ill.

I39. Motacirla ALBA Linn. White Wagtail.

I40. Budytes flavus leucostriatus (Hom.). Siberian rellow Wagtail.\|

* Deane, Bull. Nutt. Orn. Club. Vol. I. 1876. pp. 2024.

+ W. L. Walford, Bull. Nutt. Orn. Club. Vol. V, 1\$80. pp. 183 \& 184.

¥ From the Note-book of $R$. Deane.

§Jurnal for Ornithologie, Cab. II. 1854. pp. 249-253.

II Deane, Bull. Nutt, Orn. Club. Vol. V. 1880. pp. 26-30. 
141. Anthus pratensis (Linn.). Meadow Pipit.*

142. Mimus polyglottos (Linn.). Mockingbird. $\uparrow$

143. Galeoscoptes carolinensis (Linn.). Catbrd. A specimen is in the collection of the Smithsonian Institution at Washington, D. C.

144. Harporhynchus rufus (Linn.). Brown Thrasher.*

I45. Sitta CArolinensis Lath. White-breasted Nuthatch.*

146. Parus Bicolor Linn. Tufted 7 itmouse**

147. Parus atricapillus Linn. Chickadee. $\dagger$

I48. Turdus ustulatus swainsonir (Cab.). Olive-backed Thrush.*

149. Turdus annalascuk. Gmel. Dwarf Hermit Thrush. A specimen is in the collection of Geo. L. Toppan, of Chicago, Ill.

i5o. Merula migratoria (Linn.). American Robin. Specimens are in the collection of the Smithsonian Institution at Washington, D. C. A peculiarly marked specimen is in the collection of the Boston Society of Natural History. It is pure white mottled on the back with the normal color. The breast, which is white, is beautifully mottled with black or a very dark-brown.

i5I. Merula migratoria propinqua Ridgw. Western Robin. A specimen is in the collection of the Smithsonian Instituion at W ashington, D. C.

i52. Hesperocichla n.evia (Gmel.). Varzed Thrush. A specimen is in the collection of W. D. Bryant, of Oakland, Cala.

I53. Saxicola enanthe (Linn.). Wheatear.*

154. Sialis sialis (Linn.). Bluebird. A specimen is in the collection of the Smithsonian Institution at Washington, D. C.

A very handsome specimen of Alcedo ispida, of Europe, is in the collection of the American Museum of Natural History at New York. It is a perfect albino, but shows faint traces of the blue of the rump and upper tail-coverts, which looks as though seen through a silvery veil.

* Deane, Bull. Nutt. Orn. Club. Vol. V. 188o. pp. 26-30.

† Deane, Bull, Nutt. Orn. Club. Vol. IV. I879. pp. 27-30.

¥ From the Note-book of R. Deane. 
DR YOBATES NUTTALLII (GAMB.). NUTTALL'S WOODPECKER. BY B. T. GAULT.

This species, which bears a close resemblance to the Texan Woodpecker (Dryobates scalaris), may be easily recognized from the latter by the white nasal tufts and the markings of the tail feathers.

In Dryobates scalaris the nasal feathers are of a brownish-yellow; those of Dryobates nuttallii are said to be always white. The lateral tail feathers are also marked very sparingly with black; in some cases they are very nearly white. But in any case they are not marked so extensively as those of Dryobates scalaris. The white bars of the back seem to be broader, and are confined more to the dorsal region. There are other characters which serve to distinguish the species which, however, is regarded as varietal by some writers.

Two specimens of this bird, a male and female, that are now before me, show traces of a pinkish tinge on the breast; more decided on the female than in the case of the male. Young birds are said to have the whole top of the head red, as in D. scalaris.

According to our best authorities, this bird seems to be confined chiefly to the region west of the Coast Range, in California and Oregon, and found as far south as San Diego. Dr. Gambel, who first discovered this bird near Los Angeles, Cal., describing it in the Procecdings of the Philadelphia Academy of Sciences, speaks of finding it in California during all seasons.

Dr. Cooper did not observe it west of the Coast Range, except at Santa Barbara; nor did he observe any round gardens or orchards. Mr. Ridgway seems only to have met with the bird in the Sacramento Valley. Dr. Gambel describes it as having habits usual to woodpeckers. Dr. Cooper speaks of it as being a bird of very industrious habits, and not easily frightened, when hammering on the bark of trees, permitting a near approach; at other times when pursued, it become more wary and suspicious. Mr. Ridgway was struck by the peculiarity of its note, being a prolonged, querulous, rattling call, unlike that of any other bird known to him.

From the fact that not much has been said regarding this species, and particularly its breeding habits, I have deemed it worthy 
of interest to give my observations as well as those of more competent observers.

April zoth, IS62, Dr. Conper discovered a nest of this bird near San Diego. It was in a rotten stump, and was only about four feet from the ground. He captured the female bird on the nest, which contained five eggs of a pure, pearly whiteness.

$\mathrm{Mr}$. Xantus describes a nest which he found in a hole in the body of a giant cactus (Cereus giganteus), about fifteen feet from the ground. The excavation made by the bird was about a foot and a half deep and six inches wide. The nest contained two eggs. Mr. Ridgway did not make any observations on the breeding habits.

Although I have been as far south as San Diego, Cal., and as far north as the Russian River, Sonoma county, stopping at intermediate points, I have observed this bird at but one locality. This assertion, however, may not cut any figure, for my stops were necessarily short in some places. The region I refer to lies at the upper end of the San Bernardino Valley, and back from the coast about fifty miles. It is near a ranche known as "Crafton Retreat." The topography consists of mountain, hill and plain. The plain is strewn with medium sized boulders, with here and there patches of greasewood thickets, and an occasional clump of junipers. Back of the house are higher mesa lands ascending to respectable sized hills; these are treeless excepting in the canons, where a few sycamores, cottonwoods, and oaks are to be found. Near by the house, not fifteen rods away, runs a brook locally known as the Sankey, which is fed by the springs and snows of the San Bernardino Mountains. Mount Grayback stands in the distance, between fifteen and twenty miles away, though apparently but one-third that distance At the time I was there snow yet lingered on its summit. Ten miles farther away Mount San Bernardino rears his hoary head. The intervening space, or more properly speaking, the middle distance, is occupied by mountains and foot-hills, while the brook wends its way towards us, skirted on either side by cottonwoods, sycamores and alders, some of which are of considerable size. The immediate foreground, in the neighborhood of the ranche, is occupied by orange, fig, lemon, peach, apricot, and other cultivated trees. I remained two weeks in this lorely spot, spending much of my time among the birds.

I had been out on the boulder plain several hours, on the morning of April 23rd, $18 S_{3}$, collecting birds; and spying a clump of 
elder bushes in the distance, not far from the brook, the thought occurred to me that I might take a rest beneath their shade, and at the same time be ready for any strange bird that put in an appearance. These bushes, or more properly, trees, are a great deal larger shrub than our Eastern plant, their trunks growing from four to eight inches through. And if they are not the same species, their umbellate blossoms are strikingly similar, if not identical, to those of our common Eastern shrub (Sambucus canadensis).

I had hardly seated myself on an arm of the shrub when my attention was attracted to a bole in the main trunk directly above my head. At almost the same instant a bird appeared at the opening from within, and dodged back again as soon as she saw me. The movement was executed so quickly that I was unable to tell whether it was a wren or a woodpecker, but concluded that it was the latter. Upon examination of the aperture it seemed to have been lately made. Of course I thought that there would be no trouble in dislodging her, and commenced to rap on the trunk of the shrub with the butt of my gun, but this seemed to have no effect. I then walked back about fifty feet, and taking a stand, waited from ten to fifteen minutes in the hope that she would come out, affording me an opportunity to secure her and thus solve the mystery; hut in this maneuver I was also baffled. I then went up to the bush and shouted with all my might, but this did not shake her nervous system in the least, when I finally resorted to my jackknife in order to enlarge the orifice, but from its being such a tedious job, gave it up in disgust. The next morning I took a hatchet along with me, for I desired very much to know what that hole contained. It did not take me very long to cut a place large enough for me to get my hand in, and I was thoroughly surprised to learn that the bird was still on her nest. I pulled her out, and she appeared to be stupefied; dead apparently, but soon revived. Upon further inspection I found that the nest contained eggs. The bird proved to be the female of Nuttall's Woodpecker, and the eggs were pretty well advanced in incubation, and would have hatched in a few days.

The nest, which was about five and a half feet from the ground, was very near a foot deep, and about five inches wide. The hole at the entrance to the nest was but a little larger than a silver half-dollar. The eggs were six in number, their dimensions being $.85 x .66$ inches, $.87 \times .65$ inches, $.82 \times .64$ inches, $. S_{5} \times .66$ inches, $.85 \times$ x.66 inches, and $.84 \times .64$ inches, respectively. 
By the above measurements one will readily see that the eggs average very even. They are of a pearly white color, and seem to taper off, being more pointed at the small end than is usually the case among the Picida. The male of this pair, for these were the only ones seen in the vicinity, was shot a little while before at the brook.

I afterwards observed some of these birds among the oaks in the foot-hill canons, hearing their notes for the first time. Dr. Cooper mentions taking the female from the nest and perhaps this may be characteristic with the species; indeed it may be of frequent occurrence among woodpeckers, but of the many woodpeckers' nests that I have examined, none have been 'so persistent in holding the fort as Dryobates nuttallii. 


\section{DESCRIPTION OF A NEW SPECIES AND SUB-SPECIES OF THE GENUS DENDROICA.}

BY H. K. COALE.

Dendroica æstiva morcomi subsp. nov. Western rellow Warbler.

Characters: Similar to Dendroica cestiva. Colors lighter. Bill more slender. Habitat: The Western Province of North America.

Type: Adult fo. (Coll. U. S. Nat'l. Mus. No. 10,975, Fort Bridger, Utah, May 3 oth, $18_{5} 8$; C. Drexler). Breast and sides marked with rather narrow streaks of cinnamon-rufus- $D$. astiva has the breast and sides boldly streaked with broad chestnut markings.

Adult 9 : Below clear pale yellow-In $D$. cestiva the $q$ is usually streaked faintly with chestnut on the sides of the breast.

roung in the Fall: Below dusky yellow; above darker. Wing and tail feathers edged with very pale yellowish-white-In $D$. cestiva the fall birds of the year are pale yellow beneath, greenishyellow above, and the primaries and rectrices are edged with pure pale yellow.

Nestling: D. cestiva morcomi (No. 10,986 U. S. Nat'l. Mus. Fort Bridger, Utah, July I $3^{\text {th }}$, i $85^{8}$; C. Drexler). Above pale brownish. Below soiled white tinged with brown.

Nestling: D. astiva (No. 82,89 I U. S. Nat'l. Mus. Halfday, III., July 4 th, I 879 ; H. K. Coale). Above slaty-gray. Below lighter, fading into white on the belly.

A careful comparison of twenty adult spring males and ten females from Eastern states, and an equal number from the Western province proved the above characters to be constant. In fact the race is so different that the Western form can readily be distinguished from the Eastern at sight.

The National Museum is in possession of the nests and eggs of both forms, but owing to the great variation in coloration and markings of the eggs, it is impossible to describe any distinguishing characteristics.

It gives me pleasure to name this bird in honor of my esteemed friend, Mr. Geo. Frean Morcom, of Chicago, Ill. 
Dendroica dugesi sp. nov. Mexican Yellow Warbler. Type: Adult:‡ (No. 105,468 U.S. Nat'l. Mus. Moro Leon, Guanajuato, Mexico. Prof. A. Dugès).

Description: Back, occiput, and scapulars light olive-yellow. Crown, rump, and entire under parts canary-yellow; Primaries, secondaries, and two central rectrices dull black, edged with yellow. The other rectrices are yellow, except a narrow brownish-black stripe lying on the outer edge of the shafts. Centres of upper tailcoverts dusky. Breast and sides faintly marked with a few light chestnut streaks. Bill black. Legs and feet brown. The species most resembles Dendroica estiva morcomi but is much larger. Habitat, Mexico.

$\begin{array}{lccccr}\quad \text { Measurements: } & \text { Length.* } & \text { Wing. } & \text { Tail. } & \text { Tarsi. Bill (gape). } \\ \text { Dendroica dugesi } & 5.10 & 2.90 & 2.45 & .80 & .60 \\ \text { D. astiva morcomi } & 4.50 & 2.60 & 2.00 & .75 & .50 \\ \text { D. astiva } & 4.50 & 2.60 & 2.00 & .75 & .50\end{array}$

I name this unique specimen in honor of Prof. A. Dugès from whom it was received by the National Museum.

Through the courtesy of Prof. Ridgway I have recently examined the extensive series of Golden Warblers in the collection of the National Museum, and the two new races described above are the result. My acknowledgements are also due to $\mathrm{Mr}$. H. W. Henshaw for allowing me to use his specimens for comparison.

*Length taken from a dried skin.

¥Sex not marked, but evidently a male. 
LIST OF OFFICERS, STANDING COMMITTEES, AND MEMBERS OF THE RIDGWAY ORNITHOLOGICAL CLUB OF CHICAGO.

OFFICERS :

G. Frean Morcom, President.

Ruthinen Deane, Vtce-President.

H. K. CoAle, Secretary and Treasurer.

Geo. L. Toppan, Curator and Librarian. STANDING COMMITTEES.

COMMITTEE ON FINANCES.

G. Frean Morcom .................. Term expires May, 1889. Geo. L. Toppan ...................... Term expires May, I888. Benj. T. Gault....................... Term expires May, 1887. COMMITTEE ON MEMBERSHIP.

H. K. Coale ................... Term experes May, I889. J. G. Parker, Jr.................... Term expires May, 1888. Jos. L. Hancock _...................... Term expires May, 1887.

ACTIVE MEMBERS.

Coale, H. K.

Deane, Ruthven.

Fulton, H. L.

Gault, Benj. T.

Hancock, Jos. L.

Kaempfer, Fred. Jr.

Morcom, G. Frean.

Parker, J. G. Jr.
Phillips, W. A.

Reinhold, Dr. Wm.

Rice, Frank L.

Schick, Dr. Wm.

Toppan, Geo. L.

Tyrrell, F. S.

Velie, Dr. J. W.

White, A. J.

Wentworth, Frank.

HONORARY MEMBER.

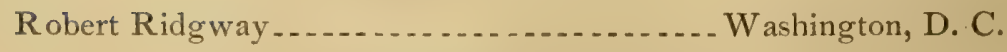

CORRESPONDING MEMBERS.

Allen, C. A . . . . . . . . . . . . . . . . Nicasio, Cala.

Allen, J. A . . . . . New York, N. 


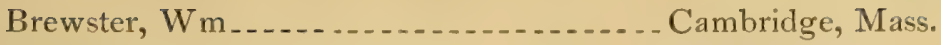

Bannister, Dr. H. M . . . . . . . . . . . . . . . . Kankakee, Ill.

Butler, Amos W . . . . . . . . . . . . . . . Brookville, Ind.

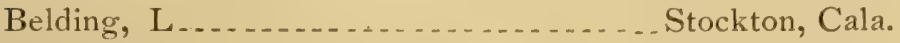

Beckham, C. W ..................... Bardstown, Ky.

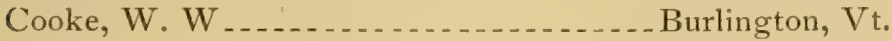

Corv, C. B...................... Boston, Mass.

Chamberlain, C. W ... . . . . . . . . . . Boston, Mass.

Chamberlain, M ...................... Johns, N. B.

Coues, Dr. Elliott .................. Washington, D. C.

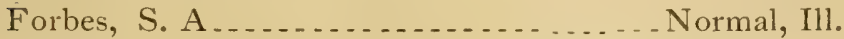

Gibbs, Dr. Morris ....................... Kalamazoo, Mich.

Henshaw, H. W .................... Washington, D. C.

Hoffman, Dr. W. J . . . . . . . . . . . Washington, D. C.

Hoy, Dr. P. L. . . . . . . . Racine, Wis.

Hurter, Julius............................... Louis, Mo.

Holterhoff, Godfrey ................. National City, Cala.

Jencks, Fred. T ....................... Providence. R. I.

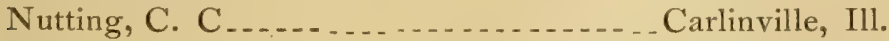

Nelson, E. W .......................... Springerville, N. M.

Purdie, H. A ........................ Boston, Mass.

Sennett, Geo. B . . . . . . . . . . . . . . . New York, N. Y.

Stephens, F ..............................

Willard, S. W . . . . . . . . . . . . . . . West De Pere, Wis.

Widmann, Otto .................... St. Louis, Mo.

Worthen, C. K ...................... Warsaw, Ill.

Waterman, G. C ...................... Larned, Kas. 










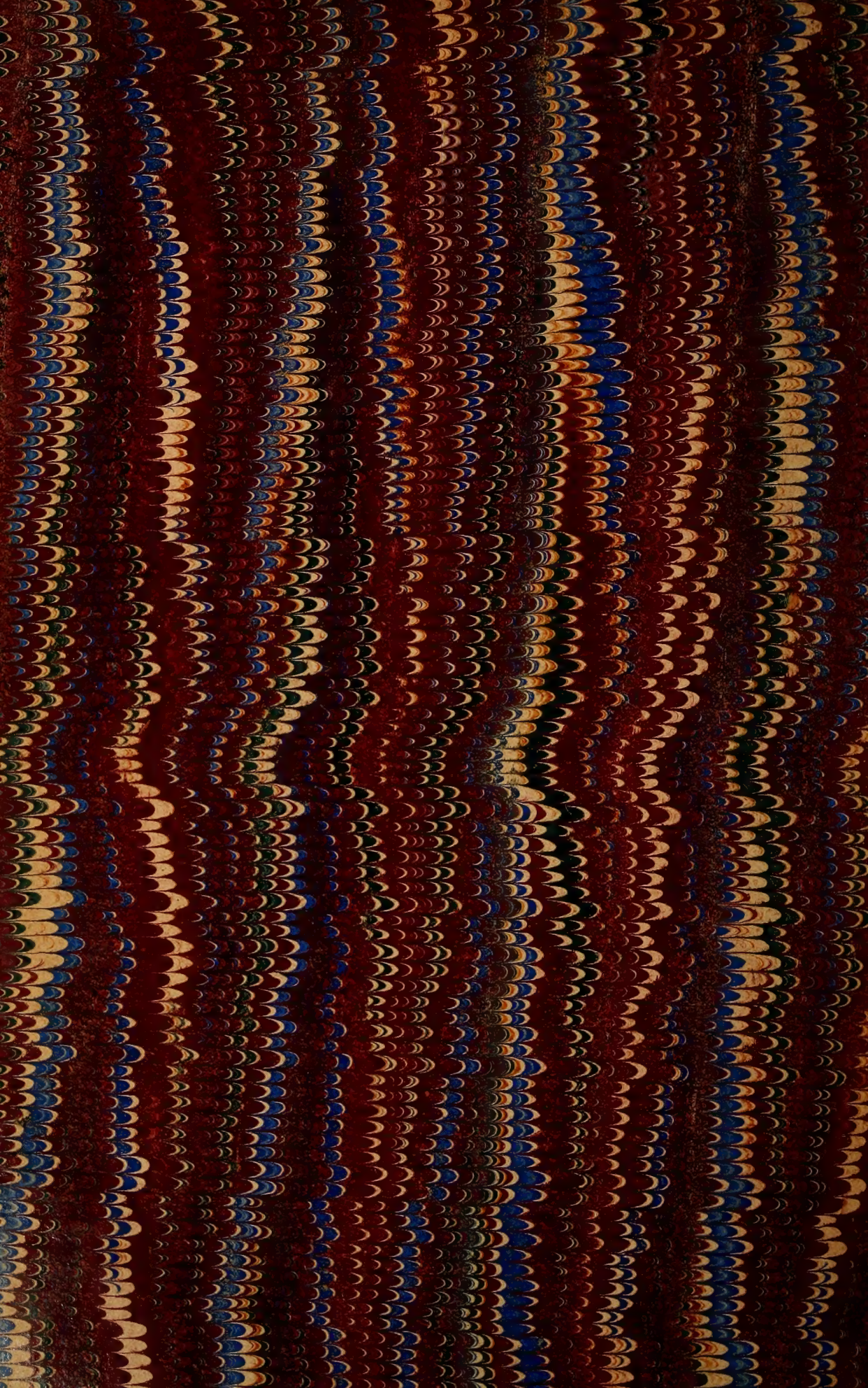




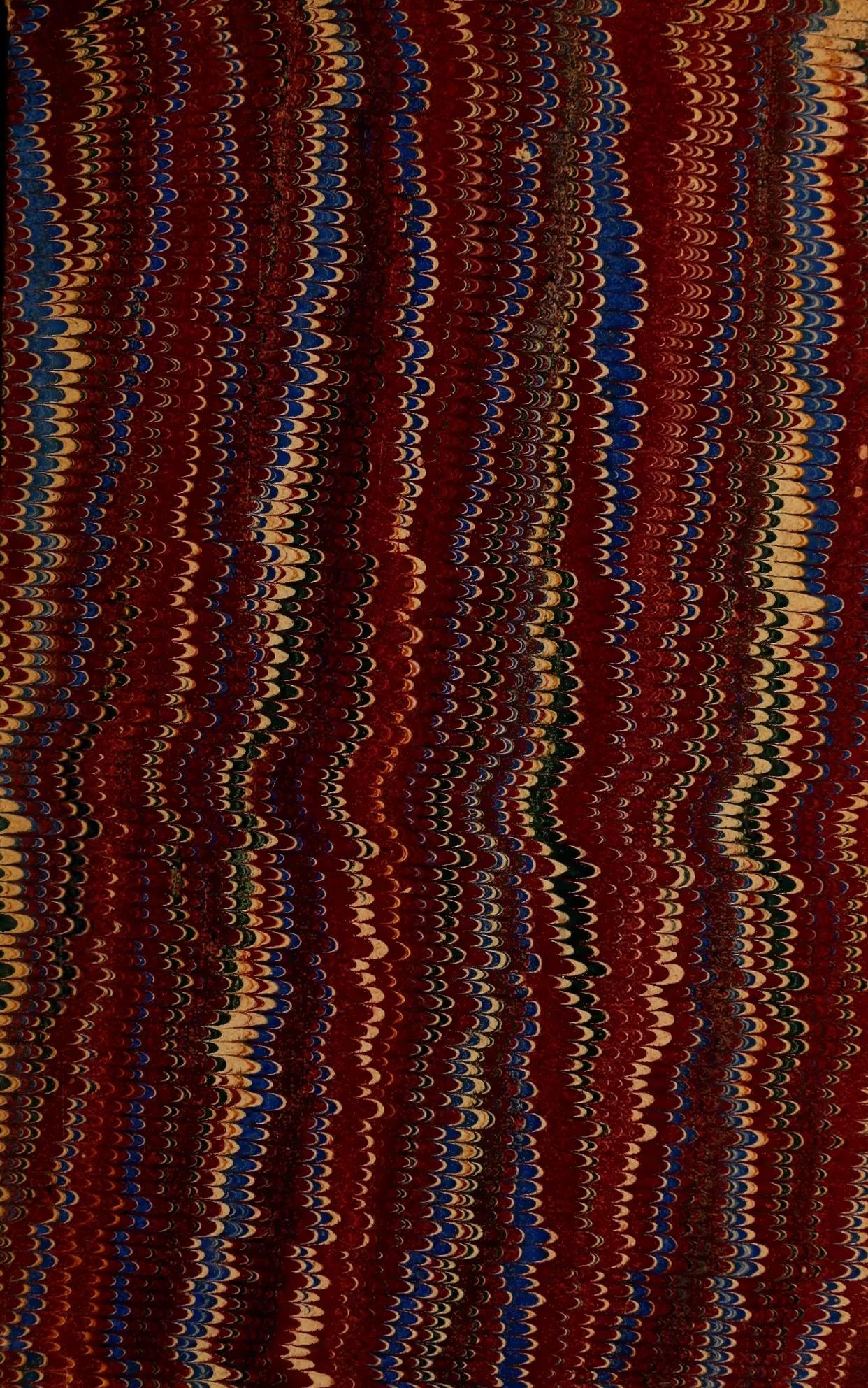




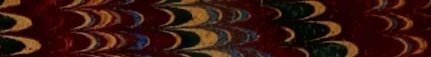

320032303

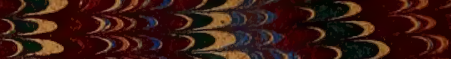

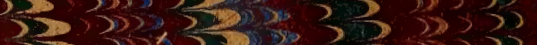

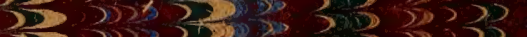

$320,350,3023$

Sid $\rightarrow 3$

$20>>3$

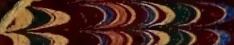

$3 \rightarrow 303$

3353

332933

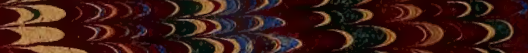

$\{3,3,35,35$

2

$3 \rightarrow 35>3$

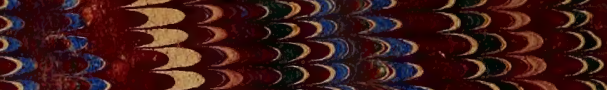

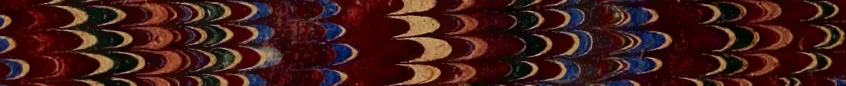

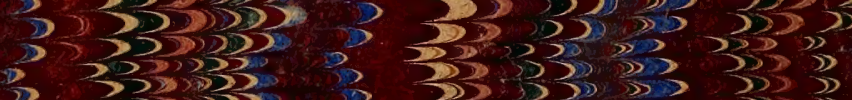

$\sum_{i}, 3333$

(j) $>3$

$3 \rightarrow 3>3$

$\frac{32}{3}>3202$

$\sum_{n=3}^{2} 3,323$

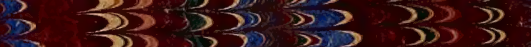

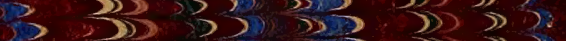

$\sum_{3}>2$

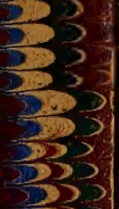

233

233

3

$\sum_{3} \sum_{3} 3$

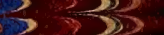

$\rightarrow 23$ i 3 ?

$\gg \gg$

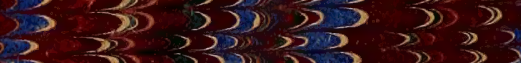

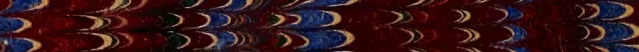

32,3203033

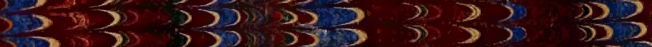

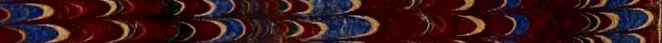

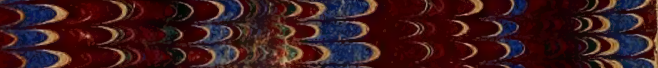

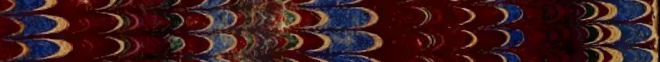

$32>35,2 \geqslant 3 \geqslant$

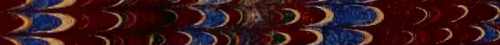

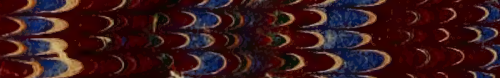

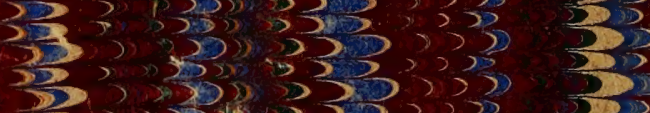

$32>>3$

$3 D>3>$ is

323,23

323,3

$3 \rightarrow 3, \gg \rightarrow 3$

$3 \rightarrow 5, \infty$

$3>3 i, 35$ ?

$3031,23\}$

$\sum 00 ? 30 ?$

$3 \sum_{3 \rightarrow \infty} \rightarrow 3$

$3 \sum_{3} D 203$

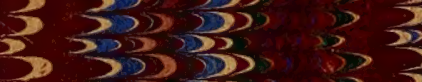

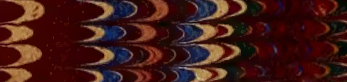

$3 \rightarrow 303$

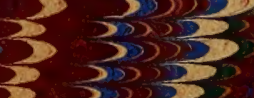

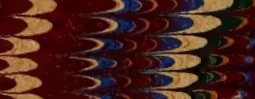

3.

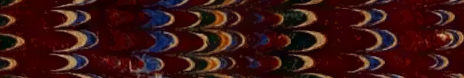

$3 \rightarrow 30203$

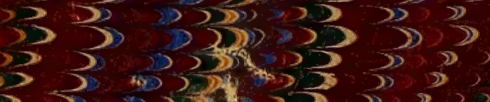

$3, x \rightarrow 3,393,3$

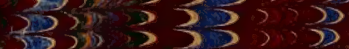

$30>3>>3$

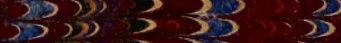

$3030,30.30$

$3 \rightarrow 33 \times 135$

2)

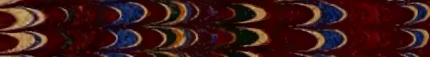

3 ?

2)

$3,3,303$

$D_{2}, \int_{3}$

235

323

$2 \int_{2}$

202

35

35

33

235

323

$\sum_{3}>$

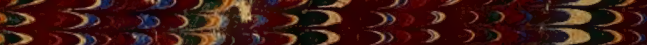

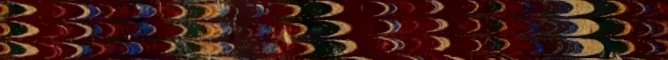

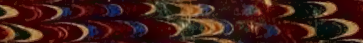

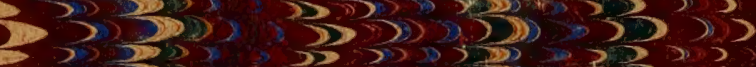

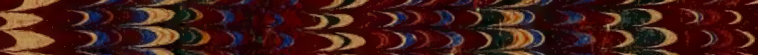

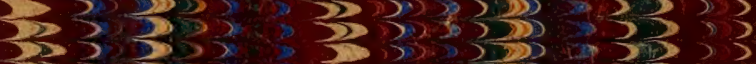

353302

323233

$3_{3} 232$

3523

3153

33253

S) 325

3 ind 3

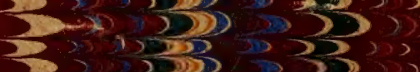

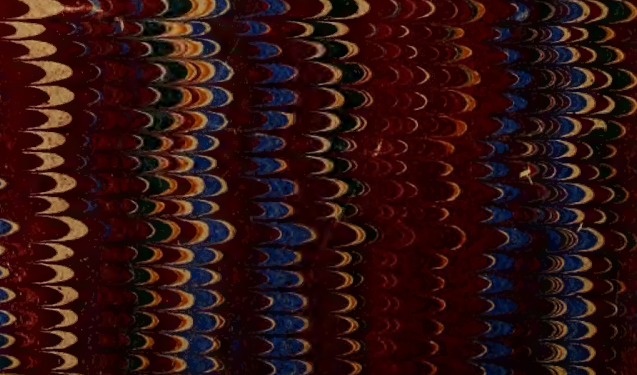

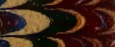

325

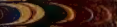

32

D)

(D)

D)

D)

(3)

AD D D M

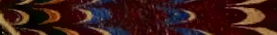

2. $>>3$

2 $>3$

33 